\title{
VARIABILIDADE E ASSOCIAÇÕES GENÉTICAS ENTRE CARACTERES DE MANDIOCA (Manihot essulenta CRANTZ) COMBINANDO POLICRUZAMENTOS E PROPAGAÇÃO VEGETATIVA
}

\author{
JESUS ACOSTA-ESPINOZA
}

Orientador: Prof. Dr. NATAL ANTONIO VELLO

Tese apresentada à Escola Superior de Agricultura "Luiz de Queiroz", da Universidade de São Paulo, para obtenção do título de Doutor em Agronomia, Área de concentração: Genética $\theta$ Melho. ramento de Plantas.

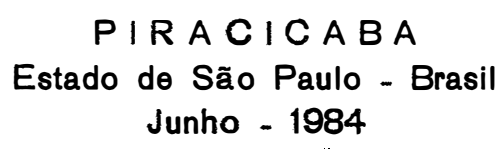


. ii.

$$
\begin{aligned}
& \text { A minha māe e } \\
& \text { irmãos } \\
& \text { OFEREÇO }
\end{aligned}
$$

A minha esposa Catalina del Carmen e bilhos,

Adreana Esmeralda, Jesus osmar,

Karla Tatiana, 
- iii.

A Memiria de meu pai

MATEO ACOSTA PEREZ

em Homenagem. 


\section{AGRADECIMENTOS}

- Ao Prof. Dr. Natal Antonio Vello, pela valio sa orientação, ensinamentos, amizade e confiança.

- Ao Conselho Nacional de Ciencia y Tecnologia e ao Instituto Nacional de Investigaciones Agrícolas do México, pelo apoio e oportunidade concedida para a realização do curso de Pós Graduação, aos níveis de Mestrado e Doutorado.

- A Escola Superior de Agricultura "Luiz de Queiroz", ESALQ, da universidade de São Paulo, através do Departamento de Genética, pelo aperfeiçoamento de minha formação científica e cultural.

- Ao Prof. Dr. Paulo Sodero Martins, pelas sugestões oportunas e apoio efetivo durante o período em que substituiu ao orientador.

- Ao Prof. Dr. Ernesto Paterniani e ao Prof. Dr. João Lücio de Azevedo, na qualidade de Diretores do Insti tuto de Gemética, pelas facilidades concedidas.

- A Seção de Raízes e Tubërculos do Instituto Agronômico de Campinas, especialmente ao Dr. José Osmar Loren zi e ao Dr. Edgar Sant'Anna Normanha, pela colaboração despreendida, fornecendo material e estímulos para a realização do presente trabalho. 
- Aos colegas do curso Irajā Ferreira Antunes e Walter Soares dos Santos Filho pelos esclarecimentos presta dos durante a redação deste trabalho; a eles e, também, a Múcio Silva Reis, Vania Moda-Cirino, Abraham Oleas, Jaime de La torre, Roberto Arevalo, Juan Medina, Fernando Patiño, Gregorio Gonzales, Juan Fernando Aguilar, pelo companheirismo em todos os momentos:

- Aos funcionários do Departamento de Genética e Instituto de Genética, especialmente à Srta. Erika Spruck, Sra. Eisa A. Azeredo Cesar, Sra. Terezinha J.L. Barrete, Sr. Mariano Aguado, Sr. Josē Monteiro, Sr. Sërgio Roberto Bertin e Sr. Luiz Carlos Veríssimo, por muitos trabalhos e extraordi nária dedicação e cortezia no atendimento.

- A esposa Catalina del Carmen Toraya de Acosta, pela compreensão, dedicação apoio e ajuda constantes.

- Finalmente, sou grato a todas aquelas pessoas que, embora não mencionadas, contribuiram direta ou indi retamente para que o curso fosse realizado. 


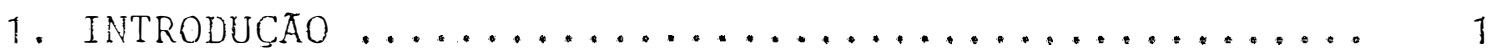

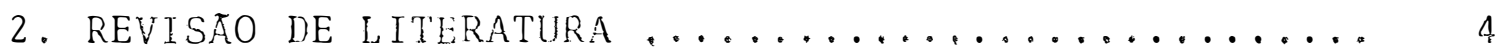

2.1. Generalidades sobre mandioca ............ 4

2.2. Genética e melhoramento da mandioca ........ 7

2.3. Técnica de policruzamentos ............... 14

2.4. Estimação de parâmetros genéticos e fenotípicos 16

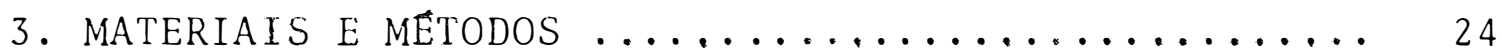

3.1. Localização, clima e solo .............. 24

3.2. Descrição do material ............... 25

3.3. Obtenção das progênies policruzadas ........ 27

3.4. Obtenção das estacas dos 17 tratamentos ..... 27

3.5. Instalação dos experimentos ............. 29

3.6. Caracteres avaliados ................. 31

3.7. Procedimentos estatístico-genëticos ......... 34

3.7.1. Anälises de variância e de covariância. 34

3.7.2. Estimativas dos componentes de variância e covariância ................. 35

3.7.3. Estimativas de parâmetros genéticos e fenotipicos ..................... 39

4. RESUltados E DISCUSSÃO ................... 44

4.1. Comportamento dos genótipos nos quatro experi-

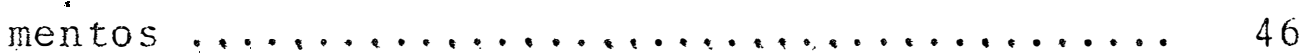

4.2. Eficiência dos policruzamentos e propagação ve

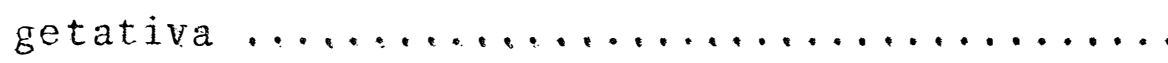


. vi

pägina

4.3. Variabilidade dos caracteres ............ 65

4.4. Associações entre os caracteres .......... 77

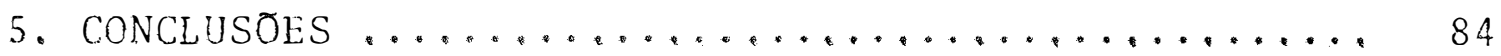

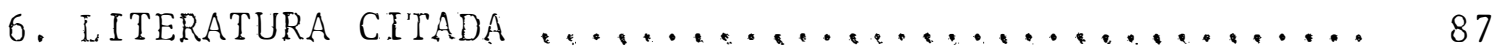

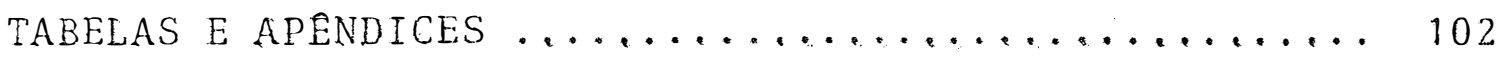


JESUS ACOSTA ESPINOZA, filho de Mateo Acosta Peréz e Maria Antonia Espinoza de Acosta, nasceu em Saltillo Coahuila, México, aos 5 dias do mês de fevereiro de 1949.

Completou as disciplinas do curso de Agronomia em 1972; defendeu a tese "Estudos preliminares sobre el culti vo de la yuca (Manihot esculenta Crantz) en el Estado de yuca tān" para obtenção do grau de Engenheiro Agrônomo em 1978 , pela então "Escuela Superior de Agricultura Antonio Nario", atualmente "universidad Autonoma Agraria Antonio Narro" na ci dade de Saltillo, Estado de Coahuila, México.

Iniciou seu trabalho profissional em 1972 como extensionista de Servicio Cooperativo de Extensão Agropecuāria, no Estado de Campeche. Em 1974 ingressou no "Instituto Nacional de. Investigaciones Agricolas" (INIA) como pesquisador do programa de forragem, no Estado de yucatān. Em 1977, com - início do programa de mandioca no INIA, foi encarregado da parte de Melhoramento Genëtico, tendo-se transferido para o Estado de Tabasco.

Iniciou em 1979 o curso de pós-graduação em "Genētica e Melhoramento de Plantas" da Escola Superior de Agricultura "Luiz de Queiroz" (ESALQ) bUniversidade de São Pau lo (USP), na cidade de Piracicaba, Estado de São Paulo, Brasil. Em 1983, defendeu a dissertação "Éficiência de policruzamentos para recombinação gênica e estimação de parâmetros geneticos em mandioca (Manihot esculenta Crantz) para obtenção do título de "Mestre em Agronomia" - Area de Concentração "Genética e Melhoramento de Plantas". Continuou os estudos na ESAL2, USP', com vistas à ob.tenção do título de "Doutor em Agronomía - Area de concentração - Genética e Melhoramento de Plantas".

Apös a conclusão de seus estudos pös-graduados na ESALQ/USP, retornarä ao México para reassumir suas funços de pesquisador junto ao programa de melhoramento genético de mandioca do INIA, no "Campo Agricola Experimental de Huimañ gillo" (CAEHUI), na cidade de Huimangillo, Estado de Tabasco, México. 
. ix.

VARIABILIDADE E ASSOCIACÕES GENETICAS ENTRE CARACTERES DE MANOIOCA (Manihot esculenta Crantz) COMBINANDO

POLICRUZAMENTOS E PROPAGACÃO VEGETATIVA

\author{
Autor: JESUS ACOSTA ESPINOZA \\ Orientador: Prof. Dr. NATAL ANTONIO VELLO
}

RESUMO

Esta pesquisa teve por objetivo a caracterização dos procedimentos envolvidos na combinação da técnica de policruzamentos com propagaçāo vegetativa, como uma metodologia que possibilita a mesmo tempo: estimar variabilidade e associaçōes genéticas entre caracteres; sintetizar populações bäsicas com potencialidade para uso em programas de melhora mento.

O material utilizado compreendeu oito progenitores e oito progênies policruzadas, Os progenitores envolve ram cultivares e linhas expeximentais selecionadas com base na alta produção de rä̈zes. As progênies policruzadas foram obtidas apōs dois anos agrâcolas.

1. ano - Os progenitores foram recombinados em lote isolado, através da técnica de policruzamentos. 
2. ano - Lote auxiliar foi instalado a partir de estacas dos progenitores e de sementes das progênies policruzas, de acordo com delineamento em blocos ao acaso, com dez repetições e três plantas por parcela. De cada planta do lote auxiliar foram coletadas quatro estacas.

A partir de estacas foram instalados quatro ex perimentos com a finalidade de avaliar os progenitores e progênies policruzadas. O mesmo delineamento anterior foi empre gado, de maneira que os quatro experimentos representaram qua tro réplicas vegetativas do lote auxiliar.

Os quatro experimentos foram conduzidos na Estação Experimental de Anhembí, do Departamento de Genética da ESALQ/USP, localizada em Piracicaba. A ärea experimental pos suia solo arenoso, e pobre en fósforo, com teores elevados de acidez e alumínio tóxico, características estas semelhantes aos solos encontrados nos cerrados brasileiros. Com dez meses pós-plantio, oito caracteres foram avaliados e submetidos às análises de variância e covariância.

A variância entre progênies policruzadas, representando progênies de meios irmãos, estima $1 / 4$ da variância genética aditiva, A variância fenotípica entre plantas dentro de progênies policruzadas estima: 3/4 da variância ge nética aditiva t variância dominante + variância ambiental. A variäncia entre plantas dentro de progênies de progenitores foi utilizada como estimativa da variância ambiental. Este 
. xi.

sistema de três equações e três incôgnitas permitiu a estimaçäo da variância aditiva e da variância dominante para cada caräter. As covariâncias genëticas aditivas foram estimadas com base na covariação entre progênies policruzadas.

Os seguintes parâmetros foram estimados: coefi ciente de determinação genotĩpica (entre progenitores), ao ní vel de plantas individuais; coeficiente de herdabilidade no sentido restrito e ao nivel de plantas individuais; grau mëdio de dominância; coeficiente genético de variação; correlações fenotípica, genëtica e experimental dos caracteres combi nados dois a dois; equações de regressão linear múltipla entre produção de raízes (variável dependente) e todas as possí veis combinações dos denais sete caracteres (variäveis inde pendentes).

os resultados àiscutidos permitiram obter as seguintes conclusões:

a. Distribuição de raízes da planta mostrou variabilidade qua se nula e dificilmente pode ser alterada por seleção.

b. Indice de colheita, altura da planta, peso da parte aérea e nümero de raízes exibiram níveis de variabilidade suficientes para a obtenção de progressos por seleção.

c. Altura da primeira ramificação, diâmetro da planta e produ ção de raízes, mostraram-se mais promissores para programas de hibridação visando-se exploração do vigor de híbrido. 
d. Distribuição, número e produção de raízes foram os caracteres com os maiores valores de correlaçóes fenotipicas e genéticas entre si.

e. Produção de raízes foi melhor explicada pela combinação de peso da parte aérea e indice de colheita.

f. Peso da parte aérea e diâmetro foram os caracteres da parte aérea mais correlacionados com produção de raízes.

g. Altura da primeira ramificação foi o único caráter que apresentou tendência de correlação negativa com produção de raízes.

h. Magnitude da variabilidade e grau de associação com outros caracteres indicaram ser o indice de colheita de muita uti lidade nos programas de melhoramento para maior produtivi dade de raízes.

i. O genótipo SRT 1099-Taquari destacourse pela elevada prodú ção de raízes e por ter transmitido alta capacidade produtiva à sua progêniepolicruzada, fatos indicadores deste genótipo possuir alta frequência de alelos favoráveis à produção de raízes.

j. A existência de genótipos com produção de raízes ao nível de $43,3 \mathrm{t} / \mathrm{ha}$ ( $50 \%$ superior ao melhor progenitor) indicou a potencialidade da população formada pelas progênies policruzadas, como fonte de material melhorado. 
.xiie.

k. O emprego combinado de policruzamentos e propagação vegetativa constituiu-se em procedimento apropriado para estimação de parâmetros que avaliam variabilidade e associações genéticas e fenotípicas entre caracteres durante a síntese de uma população melhorada de mandioca. 
GENETIC VARIABILITY AND RELATIONSHIPS AMONG CHARACTERS IN CASSAVA (Manihot esculenta Crantz) BY COMBINING POLYCROSS TECHNIQUE AND VEGETATIVE PROPAGATION

Author: JESUS ACOSTA ESPINOZA

Adviser: Prof. Dr. NATAL ANTONIO VELLO

SUMMARY

The objective of this research was to characterize the procedures involved in the combination of the polycross technique with vegetative propagation as a methodology for two concomitant purposes: 1. to estimate genetic variability and relationship among characters and, 2 . to synthesize breeding populations.

Material included eight high yielding cultivars and experimental lines of cassava as parents and, their polycrossed progenies. The polycrossed progenies were developed after two years:

First year: Selected parents were recombined in isolated field by polycross technique;

Second year: Stem cuttings of the parents and seeds of the progenies were planted according to randomized 
complete block design with 10 replications. There were three plants per plot. Four stem cuttings were taken from each plant of this auxiliary field.

By using stem cutting, four experiments were designed with the aim of to compare parents and polycrossed progenies. The experimental design was the same used in the auxiliary field.

The four experiments were carried out in Anhem bi Experimental Station, College of Agriculture "Luiz de Que roz", University of State of São Paulo, located in Piracicaba City, State of São Paulo, Brazil. This experimental station is located at $22^{\circ} 48^{\prime}$ South latitude, $48^{\circ} 07^{\prime}$. West longitude and, 469 meters of altitude. The sandy soil has low content in phosphorus, high level of acidity and toxic aluminum, similarly to the soils found in areas called "cerrado" in Brazil. Ten months after planting, all plants were measured for eight characters.

Among polycrossed progenies variances, representing half-sib progenies and corresponding to $1 / 4$ of the additive genetic variance, were estimated from analysis of variance. Phenotypic variance among plants within progenies estimated $3 / 4$ of the additive genetic variance plus dominant variance plus envirommental variance. Variance due to environment was calculated from the variation within plots shown by each parental genotype. By solving this system, were estimated dominant and additive genetic variances. Additive 
genetic covariances between characters were estimated from among progenies covariation in the analyses of covariance.

The following parameters were estimated:

coefficient of genotypic determination (among parents), in individual plant basis; narrow sense heritability coefficient, in individual plant basis; mean degree of dominance; coefficiente of genetic variation; phenotypic, genetic and experimental correlations between characters; multiple linear regression equations for root yield as the dependent variable and, all possible combinations of the other seven characters, as independent variables,

The discussed results allowed the following conclusions:

a. Root arrangement (around the stem), having a very small variability, showed just a little chance to be improved by breeding .

b. Harvest index (proportion of root weight to total plant weight), plant height, weight of the aerial part and, number of roots had genetic variability in enough amount to respond to selection.

c. Height of the first branch, plant diameter and, root yield would be easier improved in breeding programs aiming to explore hybrid vigor. 
d. Root arrangement, number of roots and root yield showed the highest values of phenotypic and genetic correlations.

e. Best prediction of root yield was done by combining weight of the aerial part and harvest index.

f. Weight of the aerial part and plant diameter were characters of the aerial part more correlated with root yield.

g. Height of the first branch was the unique character having tendency of negative correlation with root yield.

$h$. Harvest index was highly heritable, and it was an excellent auxiliary character to high yielding selection.

i. The 'SRT 1099-Taquari' genotype distinguished itself by the root yield of the parent and by transfering the yield ability to its corresponding polycrossed progeny.

$j$. The existence of plants yielding $43,3 \mathrm{t} / \mathrm{ha}$, overcoming in $50 \%$ the best parent, indicated the potential of the polycrossed progenies, as a breeding population,

$k$. Combined use of the polycross technique and vegetative propagation was an appropriate procedure for estimating parameters related to the genetic variability and relationship among characters during the synthesis of a breeding population of cassava. 


\section{INTRODUÇÃO}

A mandioca (Manihot esculenta Crantz) é uma es pécie tropical com provável origem brasileira. Suas raízes representam fonte importante de carboidratos, pois constituem -se em alimento básico para 350 milhões de pessoas, além de ser amplamente utilizada na alimentação animal e como mate. rial de industrialização. Ela inclui-se entre as espécies ve getais que poderão, no futuro, atender parte da crescente demanda mundial de energia, pois seu cultivo se estende por todas as regiões tropicais localizadas entre as latitudes $30^{\circ} \mathrm{N}$ e $30^{\circ} \mathrm{S}$, abrangendo todo o território brasileiro.

o Brasil è o maior produtor mundial com $25 \mathrm{mi}$ 1hões de toneladas de raízes, representando cerca de $20 \%$ da produção mundial (FAO, 1982). A produtividade mëdia brasilei ra é 12 t/ha, superando a produtividade média mundial em $30 \%$ Estes dois niveis de produtividade não são satisfatôrios quan 
do comparados com o potencial produtivo da mandioca, estimado por COCK (1978) em $90 \mathrm{t} / \mathrm{ha} / \mathrm{ano}$

Do ponto de vista experimental, a mandioca pos sui um conjunto de atributos muito favorảveis, pois é uma espëcie monỏica, altamente prolífica, com flores relativamente grandes e alta viabilidade de sementes, fatos que facilitam os trabalhos de autofecundaçōes e cruzamentos. Apresenta tam bém macho-esterilidade e propagação vegetativa. Este conjunto de atributos facilita a manipulação das plantas através de polinização natural ou controlada, oferecendo oportunidades excelentes para estudos de genëtica e melhoramento.

A propagação vegetativa, prätica normal de mul tiplicação comercial, torna viảvel a seleção e utilização de genötipos com caracteres agronômicos superiores em uma ünica geração, sendo esta uma vantagem significativa em relação às espëcies que se propagam apenas sexuadamente.

Apesar do interesse internacional por mandioca ser relativamente recente, uma sërie de programas de melhoramento $j \ddot{a}$ foram iniciados pelas instituições: Instituto Internacional de Agricultura Tropical (IITA), Nigëria, Africa; Cen tro Internacional de Agricultura Tropical (CIAT), na Colômbia; Instiţuto Nacional de Investigaciones Agrícolas (INIA), no México; Instituto Agronômico de Campinas (IAC) e Empresa Brasileira de Pesquisa Agropecuäria (EMBRAPA), no Brasil. 
O caráter de maior importância econômica em mandioca è a produção de raízes, cuja avaliação envolve arran quio, separação entre as partes aẻrea e subterrânea e pesagem. O conhecimento do grau de variabilidade e das associaçöes entre os caracteres indicaria se a produção de raízes po de ser estimada com base no comportamento de outros caracteres altamente herdâveis e correlacionados com produção, principalmente aqueles caracteres componentes da parte aérea cujas avaliações fossem menos trabalhosas e pudessem ser obtidas em fases iniciais do desenvolvimento da planta.

Também, seria altamente interessante a elabora ção de metodologias apropriadas para uso no desenvolvimento normal de um programa de melhoramento e que, paralelamente, fornecesse informações sobre variabilidade e associações entre os caracteres. Metodologias dessa natureza possibilitariam o desenvolvimento de programas eficientes de melhoramento, com economia de tempo, esforços e recursos.

Esta pesquisa foi efetuada com o objetivo de caracterizar os procedimentos envolvidos na combinação da téc nica de policruzamentos com propagação vegetativa, como uma metodologia para:

a. estimação de variabilidade e associações genëticas entre caracteres;

b. sintese de populações básicas com potencialidade para uso em programas de melhoramento. 


\section{REVISAO DE LITERATURA}

2.1. Generalidades sobre llandioca

A niancioca (ivanihot esculenta Crantz) pertence à família Euphorbiaceae. E consicierada uma espëcie alotetraplóide, possuindo 36 cromossomos $(x=9)$, que formam 18 bivalentes na meiose (UMANAH e HARTMANN, 1973). Existem diversas opiniōes sobre a origen desta espēcie, sencio que a maioria dos botânicos e ecológos consiciera a manáioca como una espécie originäria da América e do Nordeste do Brasil como o mais provävel centro de origem (DOMINGUEz et alii, 1982). A naior diversiảade do gênero Manihot se encontra no Brasil, México e Guatemala; GLLICK et a zii (1983) apresentam äreas de baixa, mëdia e alta diversidade da espécie. Foram os colonizadores portugueses que iniciaram a dispersão da mandioca para outros continentes.

A mandioca é una das espécies que converte a 
maior quantidace cie energia solar em hidratos de carbono por unidade de área; seu potencial produtivo pode alcançar $90 \mathrm{t} /$ ha/ano. A manaioca pode ser completamente aproveitảvel, cons tituindo-se em matéria prina de grande importância, tendo-se en vista a grande quantidade de produtos e subprodutos passiveis de seren obticios desta espécie (CONCEICARO, 1979). A ampla utilização da mandioca como alimento humano, forragem para a alimentação animal e coino material de industrialização é discutida por ACOSTA-ESPINOZA et alii (1982).

As raízes de manàioca contém 30 a $40 \%$ de matéria seca, a qual consiste, principalmente, de carbohidratos; quantidades relativamente pequenas de proteínas $(0,5$ a $1,5 \%)$ e quantidades ainda menores cie gorduras, vitaminas e sais minerais (CIAT, 1974). Resultados obtidos a partir da farinha de raízes indicam teores de 3,1 e $80 \%$ para proteínas e carbohidratos, respectivamente; na folhagem seca estes teores foram de 21 e 27 a 35\%, para proteínas e carbohidratos, respectivamente (GOMES et alii, 1982).

Muito embora a mandioca seja cultivada em mais de 80 países, dois terços da produção mundial provêm de cinco países, destacando-se o Brasil como o maior produtor com $20 \%$ da produção mundial. Encontrasse difundida por todas as regiões brasileiras, cada uma contribuindo, porém, con proporções variáveis em relação ao total produzido, de acordo com a importância sỏcio-econômica que apresenta o nível regional. Segundo NESTEL (1978), poucos são os países que cultivam - na 
para fins cie exportação. Ks exportações ça Irccionésia e da Tailância atenáeri 80 a $96 \%$ ća ceriancia do nercado internacional. Vienor escala cie exportação é liantida pelo B̈rasil, China, Tanzânia e Angola. A conuniciace Econônica Européia absor ve 80 a $90 \%$ do comërcio màial áa mancioca, para matéria frí ma na fabricação cie ração aninial, e os EüA e Canadá utilizani- na como fonte de amido inciustrial.

A mandioca é cultivaca entre os $30^{\circ}$ de latitude norte e $30^{\circ}$ de latitucie sul, suportancio altitudes desde 0 nível do mar atë 2.300 metros. Geralmente è plantada em zonas tropicais de solos pobres, once a precipitação é maior que $750 \mathrm{~mm}$ por ano. O ciclo cie crescimento (plantio-colheita) äepende das condições ambientais, variando cie nove a doze meses eni regiões quentes e alcarçancio até dois anos en regiões mais frias ou nais secas (COCK, 1982).

Existen muitos problemas agronônicos no cultivo da mandioca, entre eles pociemos mencionar os seguintes: dificulaade de se fazer colheita mecânica; râpida deterioração das raízes pôs-colheita; ataque de ruitas doenças. LOZANO e BCOT (1982) citam ảuas doenças principais: bacteriose (Xantomonas manihot) e nosaico africano; BELLOTI et alii (1982) identificam 2 c0 espécies de artrópodos que afetan a mandioca, citando 15 pragas principais; a ocorrência de ervas daninhas tambêm se constitui ruii: problena durante os três ou quatro meses de idade, havendo, entretarto, práticas culturais que podem minimizar este problema, a exemplos dos culti-. 
vos consorciados.

2.2. Genētica e mielhoramento à manciioca

Os estudos genéticos e citogenéticos em mandio ca têm sido até o momento escassos, àevicio en parte a fatores como:

- número limitado de geneticistas que se dedi cam integralmente à espécie;

- grande número (36) e tamanho reduzido de cro mossomos;

- possivel natureza poliplöide da mandioca, di ficultanco as interpretações;

- ciclo de viảa relativanente longo (ảe 9 a 24 meses), comparado com o de outras culturas;

- alta heterozigosiade, dificultando, principalmente, a obtenção de indivíduos hornozigotos para os estucios cie herança;

- as ciistintas cultivares variam muito quanto ao número de frutos e ëpoca die floração;

- Cificuldade de se utilizar un esquema de cru zarientos que se ajuste a qualquer dos mêtocios sistematicos comunente utilizados.

Assim mesmo têna sido identificados genes marca dores para três caracteres: forma do lóbulo foliar, cor das 
raízes e cor das nervuras foliares. GRANER (1942) e JOS e HRISHI (1976) estudando a herança da forma do lóbulo foliar, estreito e largo, demonstraram que a segregação apresentada está governada por um só gene. Ainda que a idade e ambiente afetem a largura do lóbulo, as cultivares podem ser distribuí das em qualquer destas duas classes. Concluiram que o alelo condicionando lóbulos estreitos é dominante sobre o que deter mina a presença de lóbuios largos. GRANER (1942). estudando a cor das raízes, concluiu que o alelo que condiciona a película marrom é dominante sobre o que determina a presença de pelícu la branca. Um terceiro carāter, correspondente à coloração roxa ou verde das nervuras foliares, tem sido utilizado como marcador genético; o número de genes que controla esse carāter, porëm, ainda näo foi estabelecido (KAWANO et alii, 1978).

Estudos preliminares, de värios

caracteres agronômicos e resistência a insetos, têm indicado que estes estão controlados por muitos genes (HERSHiEY e AMAYA, 1982). 0 conteúdo de $H C N$ nas raizes parece ser regulado por um gene re cessivo (HAHN e TEKKY, 1973). HAHN et a $i$ i (1980) assumem que a resistência às doenças bacteriose e mosaico africano são de natureza poligênica, De acordo com KAWANO (1982), características tais como-indice de colheita, ma tẻria seca da raíz e deterioração das raízes após a colheita, têm mostrado alto coeficiente de regressão entre progenitores e progênies. Menciona-se, tambëm, que a resistência às doenças bacteriose e cercospora são de incorporação relativamente fäcil, quando genótipos resistentes estão incluídos nas hibri 
dações. Estes dados sugerem, portanto, que em mandioca muitos caracteres importantes são altamente herdáveis, além disso, os efeitos genéticos aditivos são muito significativos (KAWANO, 1982).

ALLARI (1971) menciona que a experiência dos melhoristas indica que as variedades agrícolas reproduzidas assexuadamente são altamente heterozigotas e segregam amplamente quando se reproduzem por via sexual. Isto pode ser com provado em mandioca, pela ampla variação em sua descendência quando se reproduz sexualmente. Os resultados apresentados por ACOSTA-ESPINOZA et alii (1982) suportam a hipótese da man dioca ter elevada porcentagem de locos em heterozigose. KAWA NO et alii (1978), autofecundando 12 genótipos, observaram uma perda de vigor de $54 \%$ em produção de raízes, fato que evi dencia ser a mandioca altamente heterozigota; GuLICK et alii (1983) relatam a existência de aproximadamente 12.000 cultiva res de mandioca, em 14 países e 24 centros experimentais.

o conhecimento do modo de reprodução é indispensável para um programa de melhoramento genético. Dentro desse contexto, destacam-se os princípios básicos da biologia da reprodução, hábito de florescimento e polinização (GRANER, 1942a; TOLEDO, 1963; ALBUQUERQUE, 1969; VIEGAS, 1926; CONCEICAO, 1979; KAWANO, 1980). A mandioca particularmente ê uma espécie monóica que possui flores estaminada e pistilada na mesma inflorescência; a floração sempre acompanha a ramifica- 
ção do caule, de tal forma que as cultivares que não ramificam não florescem. Geralmente a maioria das cultivares florescem. As flores masculinas, são menores e ocorrem em maior nümero do que as femininas. Numa mesma inflorescência as flores masculinas situam-se na parte superior e as femininas na parte inferior. O häbito de floração é a protogínia, sendo que as flores femininas abrem aproximadamente dez dias antes das masculinas; geralmente são encontradas muitas flores masculinas e poucas flores femininas na mesma inflores cência, embora as flores masculinas e femininas de diferentes ramificações abram simultaneamente. Tanto a protoginia como a discrepância na quantidade de flores favorecem a alogamia. A época do florescimento varia com os clones e condições ambientais, NORMANHA (1971), utilizando os genötipos. Branca de Santa Catarina e IAC-7-127-Iracema, com altura de ramifica ção de 20 e $90 \mathrm{~cm}$, respectivamente, verificou que o florescimento ocorreu aos 66 e 180 dias, respectivamente. Santos Fi tho et alii (1976), citados por RAMALHO e PEREIRA (1979), apresentam dados onde o florescimento ocorreu com 66 até 180 dias. Todas os genōtifos podem florescer sob condições natu rais, desde que as condições sejam favoräveis. Segundo JENNINGS (1970), as plantas florescem preferencialmente em dias curtos do ano. De acordo com CHANDRARATNA e NANAYKKARA (1948), o estigma permanece receptivel menos de vinte e quatro horas e o pölen seco permanece viävel por cerca de seis dias. NORMANHA (1971) menciona que cada flor masculina pron duz pölen suficiente para polinizar quatro flores femininas. Este autor discute o tempo envolvido na formação de sementes, 
ou seja, o período que abrange desde a polinização até a aber tura ou deiscencia dos frutos. Esse intervalo de tempo, em mëdia, é de cerca de 80 dias, com um mínimo de 63 e um máximo de 92 dias.

A polinização cruzada na mandioca é entomófila, dando-se através de abelhas e vespas, muito embora o vento também seja um agente atuante (ALBUQUERQUE, 1969 e CONCEIÇÃO, 1979).

A polinização cruzada depende de vários fatores: época do florescimento, posição física dos genótipos, presença de insetos polinizadores, entre outros. KAWANO et alii (1978) mencionam que não existem barreiras genéticas, nem fisiológicas, para autofecundação em mandioca, Usando a cor das nervuras das folhas como marcador genético, os referidos autores não conseguiram determinar a taxa de cruzamentos, sam lientando que obtiveram muitas plantas provenientes de autofecundação, CIAT (1974), encontrou valores baixos, de 5 a $8 \%$, de polinização cruzada, utilizando a cor das nervuras das folhas como marcador genético em kärios sistemas de plantio. As pequenas porcentagens de cruzamento foram justificadas pela não coincidência de florescimento entre as fileiras masculinas e as femininas. A repetição da pesquisa, utilizando, ago ra, genótipos com diferentes-épocas de florescimento, de maneira a tornar a ocorrência do florescimento quase continua, levou à obtenção de 31 a $41 \%$ de polinização cruzada. ALBUQUER QUE (1969) observou que, devido à ocorrência de protogenia, 
grande parte das sementes obtidas por polinização natural eram resultantes de cruzamentos, devendo a mandioca ser incluída, portanto, no grupo de plantas alógamas. PEREIRA et alii (1978), utilizando como marcadores genéticos a forma do lóbulo floral e a cor da película da raíz, encontraram uma ta xa de fecundação cruzada de 63 a $100 \%$, respectivamente. ACOS TA-ESPINOZA (1983), utilizando a técnica de policruzamentos, concluiu favoravelmente para a predominância de polinização cruzada.

ACOSTA-ESPINOZA (1983) salientou que a condição de espécie monóica, altamente prolífica, com flores de ta manho adequado para fäcil manipulação, tanto em autofecundações como em cruzamentos, e a possibilidade de se empregar pro pagação vegetativa e macho-esterilidade, tornam viảvel a aplí cação de praticamente todos os métodos de melhoramento, existentes, em programas voltados para a referida cultura.

São escassos os trabalhos de melhoramento encontrados na literatura, relativosà mandioca, De acordo com NORMANHA (1971), os primeiros trabalhos de melhoramento dirigidos para essa espécie, tiveram início no Brasil em 1940,com a obtenção de sementes de polinização aberta, provenientes de genótipos portadores de caracteres agronômicos superiores, as sim como transplante de plântulas germinadas espontâneamente. Nesta época, também foi desenvolvido programa visando a obtenção de polipłöides (GRANER, 1942b) e, em continuação, iniciaram-se cruzamentos com o objetivo de se obter genötipos superiores. 
Paralelamente, tiveram inicio os trabalhos nos continentes africano e asiätico, com coletas de germoplasma, seleção e obtenção de híbridos intra e interespecíficos.

NORMANHA (1971) e PEREIRA e LORENZI (1975), men cionam que em 1948 foram inciados, no IAC, trabalhos de cruza mentos controlados, obtendo-se por seleção quatro clones para mesa e forragem, sete para fins industriais e um grupo de cultivares. Dentre 2.000 genötipos existentes no banco de germoplasma do CIAT, foram selecionadas 230 superiores em Indice de colheita e outros caracteres; doze desses genōtipos produziram mais de $50 \mathrm{t} / \mathrm{ha}$, sobrepujando significativamen te a variedade local com produção de 27 t/ha (CIAT, 1975). Atravës de seleção massal estratificada na variedade Llanera, TINEO (1977) obteve ganhos na seleção de $20 \%$ para produção total de raízes e $25 \%$ para produção de raízes comerciais, correspondentes às produções de 35 e 32 tha, respectivamente. ACostA (1978) avaliou seis variedades de baixo conteüdo de HCN, selecionadas pelo Centro de Investigaciōnes Agrí́colas do Golfo Centro, no Mẻxico, obtendo produção de 30 t/ha nas var riedades Criolla e Cubana. Em 1975, 90 cultivares e 30 híbridos provenientes do CIAT foram introduzidas no México (ACOSTA, 1979), Apös dois anos de ensaios de produção, as cultivares M Pan 51 e Mmex 59 superaram a variedade local Criolla em 64 e $62 \%$, respectivamente, sendo liberadas por HOL GUIN et a tii (1981). KAWANO (1982) menciona que o programa de fitomelhoramento do CIAT, na Colômbia, apoỏs quatro anos de 
trabalho, obteve híbridos que rendem mais de $50 \mathrm{t} / \mathrm{ha} / \mathrm{ano}$, superando as variedades locais em $100 \%$. Este progresso foi obtido com uso da seguinte metodologia: seleção de clones com base no indice de colheita e outros caracteres superiores, cruzamentos controlados, avaliação e seleção dos cruzamentos.

O objetivo do programa de melhoramento genético da mandioca consiste em se obter novos genótipos com rendi mento máximo de calorias por unidade de área e de tempo, sob diversas condições ambientais. ACOSTA (1978a) menciona os ob jetivos do programa de melhoramento do INIA, no México; GULICK et alii (1983) apresentam os objetivos do programa de melhoramento da EMBRAPA, do CIAT, do IITA e do sudeste da-Asia. Entre eles estão a alta produção de matéria seca, resistência às principais pragas e doenças economicamente importantes e adaptação ampla. E importante ressaltar a importância de no vos genótipos, obtidos atravēs de sucessivas avaliações, se leção, hibridações controladas e polinização aberta. Nos pou cos trabalhos realizados, os métodos de melhoramento mais comuns envolvem seleção, cruzamentos controlados e, em menor e $\underline{s}$ cala, cruzamentos naturais.

2.3. Tëcnica de policruzamentos

A tëcnica de "polycross" foi primeiramente des crita por H.N. Frandsen, em 1940 (WILLENSIEK, 1952), tendo si do denominada policruzamentos por VELLO (1977), Esta tëc- 
nica tem sido estudada e empregada principalmente em gramíneas forrageiras perenes e alögamas. (WHITE et a $2 i i, \quad 1968$; KNOWLES, 1969; CARLSON, 1971) e, em menor escala, em alfafa (TYSDAL e CRANDALL, 1948), beterraba açucareira, centeio, re pôlho (HEEMSTRA, 1955), mitho (GUTIERREz e SPRAGUE, 1959), br̆assicas em geral (NIEUWHOF, 1963, 1969; GOWERS, 1974), cou. ve-brócolos (ANSTEY, 1954; VELLO, 1977 e AJUDARTE NETO, 1979) mandioca (ACOSTA-ESPINOZA et alii, 1982).

A tëcnica de policruzamentos tem sido utilizada com a finalidade principal de promover a recombinação gené tica entre genötipos selecionados. Os genötipos são repetidos e arranjados sistematicamente em lote isolado, possibilitando a cada genótipo igual probabilidade de ser polinizado por qualquer outro genötipo da população. Existem pelo menos seis fatores importantes que influenciam a polinização e, con sequentemente, a eficiência dos policruzamentos: a, espaçamen to e disposição das plantas no lote isolado (NIEUWHOF, 1963 ; CARLSON, 1971); b. grau de incompatibilidade entre genótipos idênticos (NIEUWHOF, 1963, 1968, 1969); c. tempo de florescimento (FREEMAN, 1967); d. quantidade e qualidade do pólen (FREEMAN, 1967); e. atividade de vetores entomófilos (NIEUWHOF, 1963; FREE, 1970) e f. direção predominante dos ventos (NIEUWHOF, 1963; FREEMAN, 1967; CARLSON, 1971). Quando os ge nótipos selecionados apresentam diferença significativa em al tura, torna-se recomendävel a utilização de plantios intercalados, no sentido de se melhorar a distribuição dos genōtipos no lote isolado. Este cuidado deve levar a maior aproveita - 
mento das flores femininas, resultando em maior quantidade de sementes policruzadas.

Modelos para disposição em lotes de policruzar mentos, envolvendo até 50 genötipos e utilizando o princípio dos nümeros primos, foram desenvolvidos por WRIGHT (1965). Com ba se no mesmo princípio OLESEN e OLESEN (1973) definiram fórmu la de grande utilidade para orientação e disposição das plan tas que devem participar dos policruzamentos. Trata-se de um arranjo matricial correspondente a um modelo parcialmente balanceado, pois $\vec{e}$ balanceado somente nas direções principais (norte, sul, leste e oeste). Um modelo totalmente balanceado para os oito vizinhos mais proximos, ou seja, para as dire ções principais e intermediärias (nordeste, noroeste, sudes te e sudoeste) foi delineado por OLESEN (1976). Estes nodelos foram discutidos por VELLO (1977). Um mëtodo de melhoramento que pratica seleção somente dentro de progênies e recom binação por policruzamentos foi delineado por VELLO (1977) pa ra couve-bröcolos ramosa. A generalização do mëtodo para espëcies alögamas e dedução das expressōes para estimação de progresso esperado na seleção foram feitas por VELLO e VENCOVSKY (1982).

2.4. Estimação de parãmetros genēticos e fenotipicos

Coeficientes de herdabilidade, de determinação genotipica e correlaçōes genëticas e fenotīpicas, constituem 
parâmetros genético - estatísticos que caracterizam a variação genëtica e as associações entre caracteres com herança polige ê nica.

O parâmetro principal para estudo de um carâter quantitativo-ê o coeficiente de herdabilidade. HANSON (1963) define o coeficiente de herdabilidade no sentido res, trito como o quociente cntre a variância genética aditiva e a variância fenotípica de um caräter. A importância do coeficiente de herdabilidade para o melhoramento reside no fato de le expressar a validade do valor fenotípico como representante do valor genotípico de uma população (FALCONER, 1981). O conhecimento do coeficiente de herdabilidade possibilita ao melhorista predizer a eficiência de diferentes métodos de seleção e escolher o método mais apropriado para cada situação. FALCONER (1981) menciona que é importante compreender que a herdabilidade-é uma propriedade não somente de um caráter, mas tambēm da população e das circunstâncias de ambiente às quais os individuos estão sujeitos.

Em mandioca, ACOSTA.ESPINOZA (1983) estimou herdabilidade para vários caracteres agronômicos, baseando-se no comportamento de progênies policruzadas. Valores muito baixos de herdabilidade foram estimados para produção de raízes, nümero de raízes e diâmetro da planta; valor intermediário para altura da planta e valor alto para indice de colhei. ta. 
Alguns autores tem estimado coeficientes

herdabilidade com base no comportamento "per se" de cultivares geneticamente diferentes. Utilizando este procedimento, valores de herdabilidade classificados como intermediärio a alto tem sido estimados para produção de raízes de mandioca (BIRADAK et alii, 1978 ; RANALH e PLREIRA, 1979)

Considerando que um conjunto de cultivares geneticamente diferentes não representa uma população genética, uma série de autores tem substituído o termo coeficiente de herdabilidade por coeficiente de determinação genotípica (FON SECA, 1978; SERA, 1980; MARTINS e VELLO, 1981). O termo "degree of genetic determination" foi utilizado por FALCONER (1981) para definir o coeficiente de herdabilidade no sentido amplo. Os parâmetros coeficiente de determinação genotípica e coeficiente de herdabilidade no sentido amplo tem em comum, o fato dos dois termos medirem a proporção da variância feno. tipica total que -é de natureza genotípica. O fato contrastan te entre os dois termos é representado pela natureza dos efe tos genéticos: o coeficiente de determinação genotípica está relacionado com efeito genético fixo, enquanto que o coeficiente de herdabilidade no sentido amplo envolve efeito genético aleatōrio.

BARRIGA (1980) estudando a caracterização de doze genótipos de mandioca, com relação à produção de raízes e estabiiidade, obteve coeficientes de determinação genotípica mais elevados nos experimentos que tiveram menor coeficien 
te de variação experimental, tanto para produção de raízes $(b=0,52$ a 0,91$)$ como para produção da folhagem $(b=0,61 \mathrm{a}$ 0,94). ACOSTA-ESPINOZA (1983), estudando nove genötipos de mandioca, apresenta valores altos de coeficientes de determi nação genotípica para o indice de colheita e altura da planta e valores baixos para produção de raízes, número de raizes e diâmetro da planta. DANTAS (1984), no entanto, estudando 146 genötipos de mandioca, observou coeficientes de determinação genotípica altos para os caracteres produção de raizes, produ ção de hastes e cepas, produção de ramas, produção total, índice de colheita e teor de amido.

Outro parámetro importante ao melhoramento compreende as correlações entre caracteres, 0 conhecimento das correlações entre caracteres permite predizer as altera ções a serem sofridas pelos caracteres em consequência da seleção praticada sobre um carãter em particular. As correlações entre caracteres tem utilidade muito maior nas espécies perenes e nas espëcies com ciclo vital prolongado, tais como mandioca, batata, cana-de-açúcar, para as quais as predições de resposta à seleção são mais importantes. Tal fato pode ex plicar o grande número de estudos envolvendo estimativa de correlação em batatinha (MARIS, 1969; DAYAL et alii, 1972; MAITY e CHATTERJEE, 1977; GAUR et alii, 1978; PINTO et alii, 1982) e em cana-de-açücar (CESNIK, 1972; ZACARIAS, 1977; MILLER e JAMES, 1974). De acordo com FALCONER (1981), a correlação entre dois caracteres -e definida pelo quociente entre a covariância e a média geométrica das variâncias dos dois caracte- 
res. Considerando que os mesmos componentes da variância es. tão presentes na covariância, ROBINSON et alii (1951)explicam que apenas a correlação genética aditiva expressa uma inter-relação ou associação ou covariação herdável. Existem duas causas genéticas para as correlações entre caracteres: pleiotropia, causa permanente de associação entre caracteres; lig $\underline{a}$ ção gênica, causa transitória de correlação, especialmente em individuos resultantes de cruzamentos de material divergente.

Em mandioca, as primeiras estimativas de corre lação fenotípica foram obtidas por MENDES (1940) e GRANER (1946), mostrando que a produção de raízes está correlacionada positivamente com produção de folhagem (ramas e caules).

ESTEVAO et alii (1972) verificaram que peso da parte aêrea, incluindo ramas e caules, foi o único carāter que correlacionou-se positiva e significativamente com produção de raízes, para um conjunto de dez genótipos de mandioca. Re sultados concordantes com o anterior foram encontrados por AL MEIDA et alii (1976); SILVA (1977), RAMALHO e PEREIRA (1979). Quan do se considerou somente o peso de ramas, este caräter não mostrou correlação fenotípica com produção de raízes (SILVA et alii, 1983; FUKUDA et a $i \mathbf{i}, 1983$; DANTAS, 1984). Foram obser vadas correlações baixas e negativas para altura da primeira ramificação e produção de raízes e valores intermediärios a altos e positivos para correlações entre diâmetro da planta e produção de raízes por SILVA (1977). Valores intermediārios e altos foram determinados para as correlações entre -indice 
de colheita e produção de raízes por SILVA et alii (1983), FU KUDA et ai ii (1983), DANTAS (1984). No que se refere à altura da planta e produção de raízes, ESTEVAO et a zi i (1972), RI VERO (1977) e SILVA (1977) apresentam correlações intermediárias a altas e positivas; resultados contrários são apresenta dos por SILVA et alii (1983). Os ültimos autores também esti maram valores intermediärios e positivos para correlações entre nümero de raízes comerciais e produção de raízes em mandioca. NORMANHA e PEREIRA (1964) mencionam que dentro de um mesmo genōtipo existe, em geral, correlação fenotípica positiva entre produção e sete caracteres da parte aérea (altura da planta, diâmetro da rama, altura da primeira ramificação, numero de folhas, tamanho das folhas, comprimento dos pecíolos e intensidade de coloração verde da folhagem). Esta tendência precisa ser considerada com cuidado ao nível de genóti pos diferentes, pois värios autores (ESTEVAO et a zi i, 1972; CIAT, 1975; PAULA, 1976; MATOS et a $2 i i, 1980)$, tem observado que os genótipos com maior produção de raízes produzem menor quantidade de ramas.

A mandioca-ë uma espëcie que-ë propagada vegetativamente para atender aos plantios comerciais. Nos trabathos de melhoramento, hä necessidade de se utilizar a reprodu ção sexuada. Assim sendo, torna-se recomendävel avaliar as correlações entre os comportamentos dos materiais propagados vegetativa e sexuadamente. Em 269 híbridos selecionados, FU. KUDA (1979) estimou valores de correlação fenotípica apenas 
intermediärios entre os dois processos reprodutivos, tanto pa ra produção de raízes como para índice de colheita.

KAWANO (1982) observou correlações altas e positivas entre parentais e descendentes, para os caracteres: Indice de colheita, conteūdo de matéria seca nas raízes e grau de deterioração das raízes pös-colheita. Este autor, tam bém mencionou que o indice de colheita $\ddot{e}$ mais importante que a produção de raízes, tanto nos experimentos com parcelas representadas por fileiras de cinco plantas $(1,4 \mathrm{~m}$ entre fileiras e 1,0 m entre plantas dentro de fileiras), como também nos experimentos com parcelas representadas por retângulos com 30 plantas ( 5 plantas no comprimento e 0 plantas na largu ra, espaçadas de $1,0 \mathrm{~m}$ ). Foram estimadas correlações entre resultados obtidos em experimentos com parcelas em fileiras e em retângulos, cujos valores foram: $r=0,07$ para peso fres co de raízes e $r=0,61$ para indice de colheita.

Para uma espécie como a mandioca, em que o pro duto comercial são as raízes, portanto, a parte subterrânea da planta, existe muita dificuldade em se avaliar o potencial produtivo e o grau de desenvolvimento do sistema radicular, nas diferentes fases do ciclo vitalda planta. Assim, existe grande interesse em se conhecer as associações entre produção de raízes é outros caracteres, principalmente os caracteres a parte aẻrea que podem ser avaliados com certa facilidade lo go nas fases iniciais de crescimento vegetativo. O coeficien te de regressão mültipla-ë um dos parâmetros que pode auxi- 
liar o reconhecimento da melhor combinação de caracteres que deve ser considerada na seleção, no sentido de maximizar a produção de raízes. Em mandioca, dentre cinco caracteres pes quisados, o peso da parte aérea foi a única variável do modelo que influenciou significativamente a produção de raizes (ESTEVAO et alii, 1972). Todavia, SILVA (1977) observou que altura e diâmetro da planta, foram os dois caracteres que mais influenciaram a produção de raízes. 


\section{MATERIAIS E METODOS}

\subsection{Localização, clima e solo}

Os experimentos deste trabalho foram conduzi dos na Estação Experimental de Anhembí, Piracicaba, Estado de São Paulo, pertencente ao Departamento de Genētica da Escola Superior de Agricultura "Luiz de Queiroz" (ESALQ), da Universidade de São Paulo, durante o ano agrícola 1981/82. A referida estação experimental localiza-se a $22^{\circ} 48^{\prime} 00^{\prime \prime}$ de latitude sul, 4807'00" de longitude oeste, e a uma altitude de aproxi madamente 469 metros (INSTITUTO BRASILEIRO DE GEOGRAFIA E ESTATISTICA, 1957).

O clima da região, de modo geral, se caracteri za pela existência de uma estação quente e úmida coutubro a abril) e outra fria e seca (maio a setembro). As mëdias mensais de temperatura e os totais de precipitação mensal da Estação Experimental durante o tempo em que foram conduzidos os 
experimentos (setembro de 1981 a julho de 1982), são apresentadas no Apêndice. 1.

o solo em que o experimento foi conduzido caracteriza-se por apresentar textura arenosa, com pH baixo e alta concentração de elementos töxicos, especialmente alumínio, semelhantemente aos solos encontrados nos cerrados. A anảlise química encontra-se no Apêndice 2 .

\subsection{Material utilizado}

Para a realização deste trabalho foram utiliza dos 17 tratamentos envolvendo: nove genótipos selecionados pela alta produção de raizes, pelo Programa de Melhoramento da Seção de Raízes e Tubérculos do Instituto Agronômico de Campi nas (IAC) aqui designados de progenitores; e, oito progênies policruzadas, obtidas a partir dos progenitores. A progênie policruzada proveniente do genötipo IAC 105-66 Caapora não foi incluida porque não produziu flores femininas e em consequência, não houve produção de sementes. Portanto, o progeni tor IAC 105-66 Caapora contribuiu somente com pólen durante a recombinação no lote de policruzamentos.

A relação dos tratamentos, designação, classificação relativa ao conteúdo de ácido cianídrico (HCN) na pol pa crua e procedência, $\vec{e}$ apresentada a seguir. 


\begin{tabular}{|c|c|c|c|}
\hline $\begin{array}{l}\text { No do } \\
\text { trata } \\
\text { mento }\end{array}$ & Designação 1/ & $\begin{array}{l}\text { Classi- } \\
\text { ficação } \\
(\mathrm{HN}) \underline{2}\end{array}$ & Procedência \\
\hline
\end{tabular}

\section{Progenitores}

1 SRT 1 -Vassourinha

2 SRT 59-Branca de Santa Catarina

3 IAC $12-829 \underline{3}$ /

4 IAC 105-66 Caapora 4 '

5 IAC $14-18$ 5I

6 SRT 1099-Taquari

7 SRT 1139-Aipim Bravo

8 SRT 1105-Mico

9 SRT 1198-Engana Ladrão

Mansa São Paulo

Brava Sta.Catarina

Interme

diäria

Brava

Mansa

Interme

diária

Brava

Brava

Brava
Campinas

Campinas

Campinas

R.G.do Sul

Bahia

Sta.Catarina

Brasília

Progênies Policruzadas

10 SRT 1-Vassourinha - PP

11 SRT 59-Branca de Santa Catarina - PP

12 IAC $12-829-\mathrm{PP}$

13 IAC 14-18-PP

14 SRT 1099 - Taquari - PP

15 SRT 1139-Aipim Bravo - PP

16 SRT 1105-Mico - PP

17 SRT 1198-Engana Ladrão - PP

1/: SRT significa material introduzido pela Seção de Raízes e Tubérculos do IAC; IAC representa material obtido pelo programa de Melhoramento do IAC; PP simboliza progênie po licruzada, cujas sementes foram colhidas no progenitor feminino mencionado.

2/: Mansa = menos que $100 \mathrm{ppm}$ de $\mathrm{HCN}$ na polpa crua; Intermediária $=$ entre 100 e $200 \mathrm{ppm}$ de $\mathrm{HCN}$ na polpa crua; Brava = mais que $200 \mathrm{ppm}$ de HCN ha polpa crua.

3/: IAC 12-829: obtido utilizando-se o genótipo Branca de San ta Catarina (SRT 59) como progenitor feminino;

4/: IAC 105-66 Caapora: obtido utilizando-se o genótipo Branca de Santa Catarina (SRT 59) como progenitor feminino;

5/: IAC 14-18: obtido utilizando-se o genötipo Guaxupe (SRT 454) como progenitor feminino. 
3.3. Obtenção das progênies policruzadas

Em setembro de 1979 , na Estação Experimental de Tietê, o IAC instalou um lote de policruzamentos, com estą cas dos nove genótipos parentais, ou progenitores. O lote de policruzamentos cobriu uma área de $2916 \mathrm{~m}^{2}$, com 1296 plantas espaçadas $1,5 \mathrm{~m}$ entre si, distribuidas em 16 repetições de no ve parcelas contendo nove plantas. Em cada parcela, existia uma planta central, representada por um dos progenitores, ci $\underline{r}$ cundada pelos outros oito progenitores. Através de polinização entomófila, promoveu-se a recombinação de cerca de 1300 plantas. As sementes foram colhidas somente na planta central de cada parcela, As progênies policruzadas foram obtidas através de mistura de sementes produzidas pelas plantas centrais das parcelas, tendo em comum o progenitor feminino; tomou-se igual quantidade de sementes de cada uma das 16 repetições. Maiores detalhes sobre o lote de policruzamentos podem ser obtidos em ACOSTA-ESPINOZA (1983).

\section{4, Obtenção das estacas dos 17 tratamentos}

Em dezembro de 1980 realizoumse o plantio dos 17 tratamentos na Estação Experimental de Anhembí.

As sementes das progênies policruzadas foram postas a germinar em sacos de polietileno de $18 \mathrm{~cm}$ de comprimento por $8 \mathrm{~cm}$ de largura, contendo uma mistura de terra, a- 
reia e esterco de curral em quantidades iguais e esterilizada com brometo de metila. A semeadura foi realizada em 17 de outubro de 1980. Para minimizar problemas de adaptação, as plantas colocadas nos sacos plásticos permaneceram em contato direto com o meio ambiente durante 60 dias, antes de serem le vadas para o campo experimental. As oito progênies policruza das foram plantadas através de mudas com 60 dias de idade.

Os nove progenitores foram multiplicados por estacas de $20 \mathrm{~cm}$ de comprimento, retiradas do terço mëdio e inferior das hastes lenhosas. No plantio, as estacas foram colocadas no solo a $10 \mathrm{~cm}$ de profundidade média, inclinadas de um ângulo de $45^{\circ}$, de forma tal que as gemas ficaram dirigi. das para cima.

Os 17 tratamentos foram organizados em blocos ao acaso com dez repetições, Cada parcela compreendeu três plantas. As parcelas foram colocadas em fileiras, com espaça mento de 1,5 m entre plantas dentro de fileiras e de 2,0 m en tre fileiras. Em agosto de 1981, com oito meses pös-plantio, procedeu-se à colheita das plantas para avaliações preliminares (ACOSTA-ESPINOZA, 1983) e obtenção das estacas dos 17 tra tamentos. As estacas com $20 \mathrm{~cm}$ de comprimento foram retiradas dos terços mêdios e inferiores das hastes lenhosas. De cada planta foram retiradas quatro estacas que foram identif $\underline{i}$ cada com o número da parcela e da planta dentro da parcela. 
3.5. Instalação dos experimentos

Em setembro de 1981 realizou-se o plantio de nove progenitores e oito progênies policruzadas na Estação Ex perimental de Anhembí. Os $17^{*}$ tratamentos foram propagados as sexuadamente, sendo as estacas colocadas no solo aproximadamente a $10 \mathrm{~cm}$ de profundidade, inclinadas segundo um ângulo de $45^{\circ}$, de modo que as gemas ficaram voltadas para cima.

As quatro estacas originadas de uma mesma plan ta da geração anterior foram separadas para a organização de quatro experimentos. Cada experimento foi delineado em blocos ao acaso, com dez repetiçōes dos 17 tratamentos.

Cada parcela compreendeu três plantas, representadas por uma estaca. Dessa forma, embora todas as plantas dos quatro experimentos tenham sido obtidos por propagação vegetativa, ainda existiră variação genética entre plantas dentro de parcelas das progênies policruzadas.

Nota-se, pois, que os quatro experimentos representam quatro réplicas vegetativas do plantio anterior. Es te procedimento foi adotado para viabilizar a utilização de progênies policruzadas na estimação de parâmetros genéticos e fenotípicos, em condições semelhantes àquelas dos plantios co merciais, onde a propagação é normalmente feita através de estacas.

O plantio foi realizado em fileiras espaçadas 
de $2 \mathrm{~m}$. As parcelas foram distribuídas dentro das fileiras com espaçamento de $1,5 \mathrm{~m}$ entre plantas. Cada planta ocupou, portanto, uma área de $3 \mathrm{~m}^{2}$. Cada experimento envolveu

plantas por tratamento, totalizando 510 plantas individuais e ärea de $1.530 \mathrm{~m}^{2}$. Os quatro experimentos envolveram 2.040 plantas individuais e ärea de $6.120 \mathrm{~m}^{2}$ correspondendo a uma densidade de 3.333 plantas/ha. Tal densidade de plantio, inferior àquela empregada em plantios comerciais (cerca de 12.500 plantas/ha), foi utilizada para facilitar a obtenção das observações experimentais. 0 uso de espaçamento maior en tre as plantas deve ter permitido expressão mais acentuada do potencial de rendimento de plantas individuais, em consequência da menor competição intergenotípica.

Os quatro experimentos foram instalados no me mo campo experimental, de forma contígua e na mesma data. A ārea abrangendo os quatro experimentos foi acrescida de uma bordadura formada por uma fileira de plantas individuais, em todo o seu perímetro.

0 período experimental estendeu-se por dez meses, desde o plantio no campo (23-25 de setembro de 1981) até a colheita de plantas individuais (26 de julho de 1982). 
3.6. Caracteres avaliados

Todos os caracteres foram avaliados a partir de plantas individuais, no final do período experimental correspondente ao ciclo vegetativo de dez meses.

a. Attura àa primeira ramificąão

A altura da primeira ramificação das plantas foi determinada medindo-se a distância entre o nível do solo e a primeira ramificação principal da planta, em metros.

b. Aztura das plantas

A altura das plantas foi calculada medindo-se a distância entre o nível do solo e a extremidade superior da planta, em metros.

c. Diâmetro da planta

Avaliourse o diâmetro da copa da planta atravês da distância, em metros, entre duas extremidades de uma suposta circunferência, dentro da qual a maioria da copa esta va incluída.

d. Peso da parte aérea

Para avaliação do peso da parte aérea foram separa das a parte aérea (haste principal e ramas) e a parte subter- 
rânea (raízes). Assim sendo, o peso da folhagem compreendeu o peso fresco de caule mais ramos e mais folhas em $\mathrm{kg} / \mathrm{planta.}$

\section{e. Indice de colheita}

0 indice de colheita foi estimado pelo quocien te entre o peso de raízes e o peso total da planta.

\section{f. Distribuifão de raizes}

Após ser retirada cuidadosamente do solo, para minimizar os danos ao sistema radicular, cada planta foi avaliada para distribuição de raízes. Utilizou-se escala subjetiva de notas visuais:

Nota 1: excelente distribuição de raízes, ou seja, o conjunto de raízes forma circunferência em torno da inserção da estaca original.

Nota 2: regular distribuição de raízes, ou seja, as diversas raízes não formam circunferência ao redor da inserção da estaca original.

Nota 3 : ruim distribuição de raízes, ou seja, a maioria das raizes se concentra em um determinado ponto.

As notas visuais ( $x$ ) foram transformadas em $\sqrt{x+0,5}$, com a finalidade de se conseguir aproximação à dis tribuição normal, necessāria aos testes de hipótese (STEEL e 
TORRIE, 1980).

g. Numero de raizes

O número de raízes foi avaliado através da con tagem do número total de raízes por planta. Os dados de contagem foram transformados em $\sqrt{x+0,5}$, com a mesma finalidade anteriormente descrita no item $3.6 \mathrm{f}$.

h. Producão de raizes

A produção de raízes foi calculada pelo peso total de raízes frescas, em $\mathrm{kg} / \mathrm{planta.}$

3.7. Procedimentos estatistico-genēticos

3.7.1. Anāitises de variância e de covariáncia

As observações experimentais foram submetidas à análise individual e conjunta de variância para cada carāter, separadamente: altura da primeira ramificação (AR), altú ra da planta (AP), diâmetro da planta (DP), peso da p. aêrea $(P A)$, Indice de colheita (IC), distribuição de raízes (DR), número de raízes (NR) e produção de raízes (PR).

A anâlise conjunta da variância foi feita de acordo com o seguinte modelo matemâtico: 


$$
y_{i j k \ell}=m+t_{i}+s_{\ell}+(t)_{i \ell}+b_{j(\ell)}+e_{i j \ell}+d_{i j k \ell}
$$

onde:

$$
\begin{aligned}
& y_{i j k \ell}=\text { valor fenotípico de um caräter referen } \\
& \text { te à planta } k \text { do tratamento } i \text {, na repe } \\
& \text { tição } j \text { do experimento \&; } \\
& \text { m = mëdia geral do caräter; } \\
& t_{i}=\text { efeito do tratamento } i \\
& s_{\ell} \quad=\text { efeito do experimento } \ell \\
& (t s)_{i \ell}=\text { efeito da interação tratamento } i \mathrm{x} \text { ex- } \\
& \text { perimento \&; } \\
& b_{j(\ell)}=\text { efeito da repetição } j \text { no experimento } \\
& \text { \&; } \\
& e_{i j l}=\text { erro experimental associado à parcela } \\
& \text { ij do experimento } \ell \text {; } \\
& d_{i j k \ell}=\text { desvio associado à planta } k \text { na parcela } \\
& i j \ell \text {. }
\end{aligned}
$$

Os graus de liberdade dos tratamentos foram desdobrados em progenitores (P), progênies policruzadas (PP) e o contraste entre os dois grupos P VS PP (G), permitindo, assim, compararo comportamento mëdio dos progenitores com aque le das progênies policruzadas. Tambëm foram feitos os desdobramentos da interação de experimentos por P, PP e G. Estes desdobramentos e interações foram efetuados de maneira a tornar as estimativas de parâmetros genẻticos e fenotípicos representativos de cada tipo de tratatamento. o esquema de anå 
lise conjunta da variância, juntamente com as esperanças mate máticas dos quadrados mëdios, encontra-se na Tabela 1 . 0 efeito de progenitores (P) e progenitores vs progênies policruzadas [P vs PP (G)] foram considerados fixos e o efeito de progênies(PP) aleatório.

As anảlises da covariância foram efetuadas para os caracteres combinados dois a dois, conforme metodologia tradicional (STEEL e TORRIE, 1980).

Para as análises de covariância foram utilizadas as médias das três plantas de cada parcela. Assim sendo, não foi medida a covariação entre plantas dentro de parcelas. o esquema das análises de covariância é o mesmo das análises de variância (Tabela. 1 ), excluindo-se a fonte de variação (covariação) dentro de parcelas.

3.7.2. Estimativas dos componentes de variância e covariāncia

Os componentes de variância e covariância foram estimados a partir do esquema geral de análise da Tabela 1:

a. Componente quadrático da variação genotípica entre progeni tores $\left(\mathrm{V}_{\mathrm{p}}\right)$ :

$$
Q_{p}=\frac{Q_{9}-Q_{6}}{R S}
$$


b. Variância genëtica entre progênies policruzadas $\left(\sigma_{p p}^{2}\right)$ :

$$
\hat{\sigma}_{p p}^{2}=\frac{Q_{8}-Q_{5}}{R S}
$$

c. Variância do erro experimental entre parcelas $\left(\sigma_{\mathrm{e}}^{2}\right)$ :

$$
\hat{\sigma}_{e}^{2}=Q_{2}-\frac{1}{k} Q_{1}
$$

d. Variância ambiental ( $\sigma_{d p}^{2}$ para progenitores) ou fenotípica $\left(\sigma_{\text {dpp }}^{2}\right.$ para progênies policruzadas) entre plantas dentro de parcelas:

$$
\hat{\sigma}_{\mathrm{dp}}^{2}=Q_{1 P} \quad \hat{\sigma}_{\mathrm{dpp}}^{2}=Q_{1 P P}
$$

e. Variância genëtica aditiva $\left(\sigma_{A}^{2}\right)$ :

$$
\hat{\sigma}_{A}^{2}=4 \sigma_{p p}^{2}
$$

Para obter a equação anterior, considerou-se que progênie policruzadas são progênies de meios irmãos. A va riância genëtica entre progênies de meios irmãos corresponde a $(1 / 4) \sigma_{\mathrm{A}}^{2}$ (FALCONER, 1981).

f. Variância dominante $\left(\sigma_{\mathrm{D}}^{2}\right)$ :

$$
\begin{aligned}
\sigma_{\mathrm{d} p}^{2}= & \text { variância fenotípica dentro de parcelas } \\
& \text { das progênies policruzadas; }
\end{aligned}
$$




$$
\begin{aligned}
\sigma_{d_{p}}^{2}= & \text { variância ambiental dentro de parcelas } \\
& \text { de progenitores; } \\
\sigma_{d_{g}}^{2}= & \text { variância genética dentro de parcelas } \\
& \text { de progênies policruzadas. }
\end{aligned}
$$

$$
\sigma_{d}^{2}=\sigma_{d_{p p}}^{2}-\sigma_{d p}^{2}=-\frac{3}{4} \sigma_{A}^{2}+\sigma_{D}^{2}
$$

mas :

$$
\sigma_{A}^{2}=4 \sigma_{p p}^{2}
$$

então:

$$
\sigma_{d}^{2}=3 \sigma_{p p}^{2}+\sigma_{D}^{2}
$$

e:

$$
\sigma_{D}^{2}=\sigma_{d}^{2}-3 \sigma_{p p}^{2}
$$

ou :

$$
\sigma_{\mathrm{D}}^{2}=\sigma_{\mathrm{d} p}^{2}-\sigma_{\mathrm{d}}^{2}-3 \sigma_{p p}^{2}
$$

em termos de quadrados médios:

$$
\sigma_{D}^{2}=Q_{1 p p}-Q_{1}-3 \frac{\left(Q_{8}-Q_{5}\right)}{R S}
$$


.38 .

g. Variância fenotípica ao nível de médias de progênies policruzadas:

$$
\hat{\partial}_{\mathrm{F}}^{2}=\partial_{\mathrm{pp}}^{2}+\frac{1}{\mathrm{~S}} \partial_{\mathrm{spp}}^{2}+\frac{1}{\mathrm{RS}} \partial_{\mathrm{e}}^{2}+\frac{1}{\mathrm{RSK}_{\mathrm{h}}} \hat{\theta}_{\mathrm{d}}^{2}=\frac{\mathrm{Q}_{8}}{\mathrm{RS}}
$$

Quando a anảlise de variância não inclui a va-. riação dentro de parcelas:

$$
\partial_{e^{\prime}}^{2}=\frac{1}{K_{h}} \partial_{d}^{2}+\partial_{e}^{2}=Q_{2}^{\prime}
$$

e :

$$
\partial_{\bar{F}}^{2}=\partial_{p p}^{2}+\frac{1}{S} \cdot \partial_{s p p}^{2}+\frac{1}{R S} \partial_{e^{\prime}}^{2}=\frac{Q_{8}^{\prime}}{R S}
$$

h. Covariância genética entre progênies policruzadas:

$$
\text { Côv } \mathrm{pp}_{(x y)}=\frac{\mathrm{P}_{8}-\mathrm{P}_{5}}{\mathrm{RS}}
$$

i. Covariância genética aditiva:

$$
\operatorname{Côv}_{(x y)}=4 \operatorname{Cov}_{\mathrm{pp}}(x y)
$$

j. Covariânicia fenotípica ao nível de médias de progênies policruzadas : 


$$
\begin{aligned}
& \operatorname{Côv}_{\bar{F}_{(x y)}}=\operatorname{Côv}_{p p(x y)}+\frac{1}{S} \operatorname{Côv}_{s p p}+\frac{\operatorname{Côv}_{\mathrm{e}^{\prime}(x y)}}{R S}=\frac{\mathrm{P}_{8}^{\prime}(x y)}{R S} . \\
& \operatorname{Côv}_{\mathrm{e}_{(\mathrm{x} y)}^{\prime}}=\text { covariância experimental }=\frac{1}{\mathrm{~K}_{\mathrm{h}}} \text { Côv }_{\mathrm{d}}+ \\
& + \text { Côve }
\end{aligned}
$$

3.7.3. Estimativas de parämetros genēticos e fenotīpi $\cos$

a. Coeficiente de determinação genotípica ao nível de plantas individuais, para os progenitores (b):

$$
\mathrm{b}=\frac{v_{\mathrm{p}}}{v_{p}+\sigma_{e}^{2}+\sigma_{d}^{2}}
$$

Maiores detalhes sobre o coeficiente b são apresentados na revisão de literatura.

b. Coeficiente de herdabilidade no sentido restrito, ao nível de plantas individuais $\left(\mathrm{H}^{2}\right)$ :

$$
H^{2}=\frac{4 \sigma_{p p}^{2}}{\sigma_{p p}^{2}+\sigma_{e}^{2}+\sigma_{d p p}^{2}}
$$

c. Grau mëdio de dominância (gmd)

$$
\text { gmd }=\sqrt{\frac{2 \sigma_{D}^{2}}{\sigma_{A}^{2}}}
$$


gmd $=0$, indica ação gênica aditiva

gmd $=1$, indica dominância completa

$0<$ gmd $<1$, indica dominância parcial

gmd > 1, indica sobredominância

d. Coeficiente de variação genética $\left(\mathrm{CV}_{\mathrm{g}}\right)$ :

$$
\mathrm{CV}_{\mathrm{g}}=\frac{\sqrt{\sigma^{2}}}{\overline{\mathrm{x} p}} \cdot 100
$$

onde:

$$
\bar{x}=\text { média do caráter. }
$$

e. Coeficientes de correlação genética $\left(\mathrm{r}_{\mathrm{A}}\right)$, fenotípica $\left(\mathrm{r}_{\overline{\mathrm{F}}}\right)$, e experimental $\left(r_{e}\right)$

A partir das estimativas dos componentes da va riância e covariância, foram calculadas as correlações entre os caracteres combinados dois a dois (xy), fazendo-se:

$$
\begin{aligned}
& r_{A(x y)}=\frac{\operatorname{Côv}_{A(x y)}}{\sqrt{\hat{\sigma}_{A(x)}^{2} \cdot \hat{\sigma}_{A(y)}^{2}}} \\
& r_{\bar{F}}(x y)=\frac{\operatorname{Cov}_{\bar{F}}(x y)}{\sqrt{\hat{\sigma}_{\bar{F} x}^{2} \cdot \hat{o}_{\frac{F}{2}}^{2}}}=\frac{P_{8(x y)}}{\sqrt{Q_{8}(x) \cdot Q_{8(y)}}} \\
& r_{e(x y)}=\frac{C_{\hat{o v}} e^{\prime}(x y)}{\sqrt{\hat{\partial}_{e^{\prime}(x)}^{2} \cdot \hat{\partial}_{e^{\prime}(y)}^{2}}}=\frac{P_{2}^{\prime}(x y)}{\sqrt{Q_{2}^{\prime}(x) \cdot Q_{2}^{\prime}(y)}}
\end{aligned}
$$




$$
\begin{aligned}
& \mathrm{r}_{\mathrm{A}(x y)}=\text { estimativa do coeficiente de correlação } \\
& \text { e y ao nivel de médias de parcelas. } \\
& r_{\bar{F}(x y)}=\text { estimativa do coeficiente de correla- } \\
& \text { ção fenotípica entre caracteres } x \text { e } \\
& y \text {, a.o nivel de médias de progênies po } \\
& \text { licruzadas; } \\
& \mathrm{r}_{\mathrm{e}(\mathrm{x} y)}=\text { estimativa do coeficiente de correla- } \\
& \text { ção experimental entre os caracteres } \\
& x \text { e } y \text {, ao nível de médias de parcelas. }
\end{aligned}
$$

A correlação experimental é calculada a partir dos resíduos das análises de variância e covariância. Portan to, a correlação experimental mede o grau de associação líqui da entre dois caracteres $x$ e y, ou seja, a associação que per manece entre os caracteres $x$ e y após a retirada de todos os efeitos associados às fontes de variação e covariação controladas pelos experimentos. Tal coeficiente é, pois, função do tipo de experimento e da natureza dos tratamentos utilizados nos experimentos. Na presente pesquisa, as plantas das parce las dos progenitores possuem somente diferenças ambientais ; no entanto, as plantas das parcelas das progênies policruzadas possuem diferenças ambientais e genéticas. Pelas duas razões consideradas, decidiu-se pela introdução do termo correlação experimental, como uma alternativa mais representativa do que o termo correlação ambiental. 
f. Regressão linear múltipla

As associações múltiplas dos caracteres avalia dos com produção de raízes, foram pesquisadas através da regressão linear mưltipla, utilizando-se o modelo:

$$
Y_{j}=b_{0}+b_{1} x_{1 j}+b_{2} x_{2 j}+\ldots+b_{m} x_{m j}+e_{j}
$$

onde :

$$
\begin{aligned}
\mathrm{Y}_{j}= & \text { variāvel dependente (produção de raízes) } \\
\mathrm{b}_{0}= & \text { termo constante } \\
\mathrm{b}_{1}= & \text { coeficiente de regressão parcial para o } \\
& \text { caráter } 1 ; \\
\mathrm{b}_{\mathrm{m}}= & \text { coeficiente de regressão parcial para o } \\
& \text { caräter } m .
\end{aligned}
$$

Considerando que o modelo utilizado baseia-se nos coeficientes de regressão parcial, todas as inter-relações entre os caracteres (variáveis independentes) estão incluidas. Dessa forma, a magnitude do coeficiente de regressão linear indica diretamente o grau de associação do caráter envolvido e a produção de raízes.

Também, utilizou-se a técnica de adição unitária de variảveis (passo a passo) relatada por DRAPER e SMITH (1966) para estimar a contribuição relativa de cada caráter na explicação da variação observada na produção de raízes. As sim, um determinado caráter terá importância para explicar 
parte da variação observada na produção de raízes quando a adição deste caráter à equação de regressão múltipla provocar alteração pronunciada no valor do coeficiente de determinação $\left(R^{2}\right)$ da equação.

Foram estimados os erros associados às estimativas de parâmetros genéticos. As expressões necessārias para estimação de tais erros foram obtidos pela utilização da metodologia de VELLO e VLNCOVSKY (1974). 


\section{RESULTADOS E DISCUSSÃO}

Os quatro experimentos considerados envolveram, inicialmente, um total de 17 tratamentos. Todavia, as análises estatístico-genéticas compreenderam 16 dos tratamentos, excluindo-se o progenitor SRT 1139-Aipim Bravo, devido à sua alta susceptibilidade à bacteriose, causada por Xanthomonas manihotis, o que implicou em falhas de quase $100 \%$ nas par celas com este progenitor.

A sobrevivência de plantas por parcela foi relativamente alta, pois para um total de 1920 plantas ocorreram 239 falhas (12\%), durante o período experimental de dez meses. Esta porcentagem de falhas encontra-se dentro dos padrões normais de experimentação, de maneira a assegurar precí são experimental satisfatória. O espaçamento relativamente amplo utilizado $(1,5 \times 2,0 \mathrm{~m})$ alẻm de permitir que cada genó- 
tipo tivesse condições ambientais adequadas para expressão de seu potencial produtivo, também contribuiu para reduzir a com petição intergenotípica e, consequentemente, deve ter minimizado o efeito compensatório esperado de uma falha sobre plantas sobreviventes vizinhas, com reflexos positivos na pre cisão experimental. Outro fator que deve ter favorecido uma melhor precisão experimental foi a utilização de propagação vegetativa tanto para os progenitores quanto para as progênies policruzadas; este cuidado experimental deve ter possibi litado comparação realística entre os progenitores e suas res pectivas progênies.

A distribuição de raizes e o indice de colheita apresentaram os mais baixos coeficientes de variação experimental nas análises conjuntas $(8,2$ e $11,5 \%$, respectivamen te), enquanto que a produção de raízes $(32,3 \%)$ e o peso da fo lhagem $(36,2 \%)$ apresentaram os mais altos valores de coeficientes de variação (Tabela 2 ). O coeficiente de variação ex perimental relativamente baixo observado para o índice de colheita parece ser uma tendência generalizada em mandioca,pois outros autores (ACOSTA-ESPINOZA, 1983; FUKUDA et alii, 1983; SILVA et alii, 1983; DANTAS, 1984) também obtiveram valores ao redor de $10 \%$ para este caráter.

Os valores relativamente altos de coeficiente de variação observados para produção de raízes ( CV $=32,8 \%$ ) e peso da folhagem $(36,2 \%)$ também parece ser uma tendência ge 
ral, pois os resultados foram corroborados por outros autores (PAULA, 1976; BARKIGA, 1980; FUKUDA et a $i i i, 1983$; DANTAS, 1984). Uma possível explicação para os elevados coeficientes de variação observados seria o grande número de genes provavelmente relacionados às heranças dos caracteres produção de raízes e peso da parte aérea, associado com o longo período necessärio para a planta atingir o ponto de colheita, de maneira a intensificar a influência ambiental.

4.1. Comportamento dos genötipos nos quatro experimentos

A Tabela 2 relata um resumo das anälises conjuntas de variância para todos os oito caracteres pesquisados. Embora tenham sido detectadas diferenças significativas entre experimentos para sete dos oito caracteres considerados, as interações experimentos $x$ progenitores, experimentos $x$ pro gênies policruzadas e experimentos $x$ grupos foram sempre não-significativas, Este fato, associado com a semelhança (critério de BOX, 1954: quociente entre o maior e o menor quadrados médios no máximo igual a 4) entre os valores dos quadrados médios residuais de cada caráter, obtidos nas análises in dividuais dos experimentos, permitem que os resultados sejam apresentados e discutidos em termos médios representativos do conjunto dos quatro experimentos, Com isto, a estimação de parâmetros torna-se mais representativa, pois o comportamento de cada genótipo poderá ser baseado em até 120 plantas estratificadas em 40 parcelas (10 repetições $x 4$ experimentos). 
Dé acordo com a Tabela 2, existem diferenças significativas tanto entre progenitores como também entre pro gênies policruzadas, para todos os oito caracteres. Dois fatos são relevantes na Tabela 2: o primeiro fato compreende a superioridade constante para todos os caracteres da magnitude dos quadrados mẻdios dos progenitores em relação às progênies policruzadas; o segundo fato relaciona-se à inferioridade constante para todos os caracteres da magnitude dos quadra dos médios estimados dentro de progenitores em relação aos quadrados médios dentro de progênies policruzadas.

$\mathrm{Na}$ Tabela 3 encontram-se as médias observadas, e nas Tabelas 4 e 5 são apresentados os limites inferior, superior e a amplitude de variação dos oito caracteres, para progenitores e progênies policruzadas. O comportamento dos genótipos para cada carāter é a seguir apresentado, estando baseado nas Tabelas 3,4 e 5 .

a. Altura da primeira ramificacão

Entre os progenitores, a altura da primeira ra mificação variou de 0,20 a $0,95 \mathrm{~m}$, com média igual a 0,43 m. As progênies mostraram plantas com altura da primeira ramificação de 0,20 a $2,60 \mathrm{~m}$ e média de $0,54 \mathrm{~m}$. Os genótipos SRT 1105-Mico, IAC 14-18, SRT 1-Vassourinha e IAC 12-829 apresentaram menor altura de ramificação, tanto para progenitores como para suas respectivas progênies policruzadas. A progênie po- 
licruzada SRT 1139-Aipim Bravo também apresentou baixa altura de ramificação. Os genótipos IAC 105-66. Caapora, SRT 1099-Taquari, SRT 59-Branca de Santa Catarina e SRT 1198-Engana Ladrão apresentaram a mior altura da primeira ramificação da planta entre os progenitores, enquanto que SRT 1198-Engana La drão, SRT 1099-Taquari e SRT 59-Branca de Santa Catarina foram os de maior altura de ramificação entre as progênies polí cruzadas; pode-se observar, claramente, que as médias de amplitude foram maiores entre progênies policruzadas $(1,03 \mathrm{~m})$ do que entre progenitores $(0,28 \mathrm{~m})$.

Segundo COCK (1982) as causas que influenciam as ramificações em mandioca não são conhecidas. $0 \ldots$ nümero mais comum de ramos é de 2 ou 3 em cada ponto de ramificação; CIAT (1978) menciona que ótimos níveis de rendimento em raízes foram observados em genótipos que ramificam entre 8 e 10 meses após o plantio. Genótipos com maior altura da primeira ramificação têm a vantagem de permitir melhor aproveitamento de propágulos para as semeaduras posteriores, além de facilitarem o estabelecimento de culturas consorciadas. Os limites superiores observados nas progênies policruzadas (Tabela permitem antever a possibilidade da altura da primeira ramifi cação poder ser alterada por seleção.

b. Artura da pranta

A altura da planta variou de 1,30 a $3,03 \mathrm{~m}$, com média de $2,05 \mathrm{~m}$ entre os progenitores. No que se refere 
às progênies policruzadas, a altura variou de 1,02 a $2,88 \mathrm{~m}$, sendo a mëdia igual a $1,92 \mathrm{~m}$. Os genótipos SRT 1 -Vassourinha e SRT 1105-Mico foram os que apresentaram as menores alturas da planta entre os progenitores e entre suas respectivas progênies policruzadas, Os genótipos IAC 105-66-Caapora, SRT-1198 -Engana Ladrão, SRT 1099-Taquari e SRT 59-Branca de Santa Catarina apresentaram maior altura entre os progenitores, enquanto que as progênies policruzadas SRT 1198-Engana Ladrão, SRT 1099-Taquari e SRT 1199-Aipim Bravo foram as de maior altura. A amplitude média foi maior nas progênies policruzadas $(1,29 \mathrm{~m})$ que nos progenitores $(0,74 \mathrm{~m})$.

A seleção de genótipos de porte reduzido é importante em regiões sujeitas a ventos fortes, visando, com is so, minimizar a ocorrência de acamamento, Tal situação seria mais evidente caso tais äreas apresentassem, tambẻm, solos férteis. Nessas circunstâncias, genótipos de porte baixo apresentariam altura mínima necessária para o desenvolvimento de reações fisiológicas em intensidades normais. Por outro lado, genótipos com porte alto seriam recomendáveis para regiões com baixa fertilidade de solo. A segregação transgressiva observada tanto para altura superior como para altura in ferior (Tabela 4) indica a possibilidade de se selecionar plan tas com maior ou menor altura, dependendo das circunstâncias envolvidas. Para este tipo de seleção, seria importante considerar conjuntamente altura da planta e altura da primeira ramificação, no sentido de se obter ideotipo fisiologicamente 
mais eficiente.

c. Diâmetro da planta

Entre os progenitores, o diâmetro da planta va riou de 1,13 a 2,63 m, com média de 1,96 m. As progênies policruzadas mostraram plantas de 0,95 a 2,65 m e média de 1,71 m. Os genótipos com menor desenvolvimento em diâmetro foram SRT 1-Vassourinha, SRT 1105-Mico e IAC 14-18, tanto entre pro genitores como entre suas progênies policruzadas. Os genótipos SRT 59-Branca de Santa Catarina, SRT 1198-Engana Ladrão e SRT 1099-Taquari foram os progenitores mais desenvolvidos em diâmetro da planta. Dentre as progênies policruzadas mais de senvolvidas destacam-se SRT 1139-Aipim Bravo, SRT 1198-Engana Ladrão e SRT 1099-Taquari. A média de amplitude foi menor nos progenitores $(0,80 \mathrm{~m})$ que nas progênies policruzadas $(1,31 \mathrm{~m})$.

Existem evidências de que o diâmetro da planta está relacionado ao número de ramificações da parte aérea da planta; as causas de ramificação em mandioca, todavia, não são ainda conhecidas (COCK, 1982).

O diâmetro da planta é um caráter de muito interesse, uma vez que aumentos na densidade populacional reque rem o emprego de genótipos com menor diâmetro, tendo-se em vista a obtenção de níveis de produtividade mais elevados por unidade de área. Atualmente, em plantios comerciais são uti- 
zadas populações em torno de 12.500 plantas/ha. Aumentos na população de plantas, com base em genótipos adequados a essa finalidade, elevariam, como consequência, a produção de raízes por ärea, determinando, também, diminuições no tamanho mé dio das raízes, o que facilitaria os trabalhos de colheita em plantios comerciais destinados à indústria. Genótipos com me nor diâmetro da planta poderão ser selecionados nas progênies policruzadas (Tabela 4).

d. Peso da parte aérea

Entre os progenitores o peso da p. aérea variou de 1,120 a $12,678 \mathrm{~kg} / \mathrm{planta,} \mathrm{com} \mathrm{média} \mathrm{igual} \mathrm{a} 5,405 \mathrm{~kg} /$ planta. Entre as progênies policruzadas foi verificada uma variação de 0,990 a $12,985 \mathrm{~kg} / \mathrm{planta,} \mathrm{com} \mathrm{média} \mathrm{de} \mathrm{4,176} \mathrm{kg/}$ planta. Os genötipos com menor peso da p. aërea foram SRT 1-Vassourinha, SRT 1105-Mico e IAC 12-829, tanto para os proge nitores como para suas progênies policruzadas. Os genótipos SRT 1198-Engana Ladrão, IAC 105-66-Caapora e SRT 1099-Taquari apresentaram maior peso da. p.aérea. entre os progenitores. En tre as progênies policruzadas destacaram-se os genótipos SRT 1139-Aipim Bravo, SRT 1198 -Engana Ladrão e SRT 1099-Taquari. De acordo com a Tabela 4, a amplitude média foi inferior nos progenitores $(6,205 \mathrm{~kg} / \mathrm{planta})$ e maior nas progênies poli cruzadas $(8,182 \mathrm{~kg} / \mathrm{planta})$.

Basicamente, não existem estudos de seleção de 
genótipos visando o peso da p. aérea. CONCEIÇAO (1979) destạ ca a importância da utilização da parte aérea da planta. o pe so da p. aérea pode ter interesse no sentido de se identificar a existência de possiveis associações deste com outros ca racteres agronômicos.

e. Indice de colheita

Entre os progenitores, o indice de colheita va riou de 0,32 a 0,71 , sendo a média igual a 0,56 ; entre as pro gênies policruzadas observou-se variação de 0,33 a 0,72 , com média de 0,56. Portanto, para índice de colheita, progenitores e progênies policruzadas tiveram comportamento médio muito semelhante. Os genótipos SRT 1-Vassourinha e SKT 1105-Mico foram os que apresentaram indices de colheita superiores entre progenitores, assim como com relação a suas respectivas progê nies policruzadas. O genótipo SRT 1198-Engana Ladrão foi o progenitor que manifestou o menor índice de colheita. Entre as progênies policruzadas os menores indices de colheita foram registrados para SRT 1139-Aipim Bravo e SRT 1198-Engana La drão, enquanto que os demais genótipos apresentaram valores intermediärios. A amplitude média foi de ordem de 0,20 e 0,27 para progenitores e progênies policruzadas, respectiva mente.

Os genótipos com crescimento da parte aẻrea de masiadamente vigoroso geralmente têm indices de colheita mui- 
to baixos (CIAT, 1975). Resultados obtidos por ACOSTA-ESPINO ZA (1983) mostraram algumas exceções à essa tendência, à seme Ihança do que foi encontrado na presente pesquisa. Assim sen do, genótipos de crescimento vegetativo (altura e diâmetro) vigoroso, como SRT 59-Branca de Santa Catarina e SRT 1099-Taquari, podem relacionar-se a-indices de colheita $(0,56$ e 0,58 respectivamente) não muito diferentes daqueles apresentados por genótipos de crescimento mais reduzido, a exemplo de SRT 1-Vassourinha e SRT $1105 \mathrm{mico}$ (Índice de colheita igual a 0,63). Realmente, as médias de índice de colheita apresentadas pelos genótipos SRT 59-Branca de Santa Catarina e SRT 1105-Mico, contrastando em vigor, estão muito próximas de 0,60, valor considerado como ideal em mandioca (KAWANO, 1982). E importante mencionar que entre as progênies policruzadas ob servou-se plantas com indices de colheita iguais a 0,67, conforme constatado para SRT 59-Branca de Santa Catarina e SRT 1099-Taquari (Tabela 5). Um genótipo ideal caracteriza-se por apresentar elevada produção de raízes associada ao índice de colheita em torno de 0,60. Desse modo, uma elevada produção de raízes, deveria representar pelo menos $60 \%$ do peso total da planta, situação esta que definiria um genótipo ideal entre as progênies policruzadas.

f. Distribuisão de raizes

Entre os progenitores a distribuição de raízes variou de um nível adequado $(1,323)$ para um nível inadequado 
(1,768), sendo a média igual a 1,54. Entre progênies policru zadas a variação registrada foi de 1,225 a 1,871 , com média igual a 1,57. Os genótipos que apresentaram os menores valores, ou seja, a melhor distribuição de raízes, foram IAC 12-829, IAC 14-18 e SRT 1099-Taquari. Os progenitores SRT 1 Vassourinha e SRT 1105-Mico, mostraram distribuição de raízes ruim. Entre as progé es policruzadas, os genótipos que apre sentaram valores altos indesejảveis de distribuição de raízes foram SRT 1-Vassourinha e IAC 12-829; valores baixos desejáveis ocorreram para SRT 1099-Taquari, SRT 1105-Mico e IAC 14-18. A amplitude mëdia foi igual a 0,303 para progenitores e 0,513 para progênies policruzadas.

A distribuição de raízes é um fator de muita importância, tanto no que diz respeito aos aspectos relaciona dos a maior ou menor facilidade de colheita, como no que concerne ao nümero de raízes e, consequentemente, à produção.Não foi encontrado na literatura nenhum trabalho voltado para seleção neste caráter. De acordo com a Tabela 5, algumas progệ nies policruzadas mostraram valores mais baixos, portanto, mais desejáveis do que os valores de seus progenitores, evidenciando a possibilidade de se praticar seleção para melhor distribuição de raizes.

g. Wumero de raizes

o nưmero de raizes entre os progenitores va- 
riou de 3,8 (ou 2,074 após transformações) a 20,3 (ou 4,561 transformado), com mëdia igual a 10,5 raízes (ou 3,31 transformado); entre as progênies policruzadas a variação foi de 3,7 a 24,3 raízes (ou 2,049 a 4,980 transformado), com média igual a 10,3 raízes (ou 3,280transformado). Os genótipos SRT 1099-Taquari e IAC 14-18 foram aqueles que apresentaram maior número de raízes, tanto entre os progenitores como entre suas progênies policruzadas. As progênies policruzadas IAC 12-829 e SRT 1-Vassourinha foram as que apresentaram menor núme ro de raízes. A amplitude mëdia foi 1,3 raízes (ou : 1,352 transformado) entre progenitores e 4,2 raizes (ou 2,160 trans formado) entre progênies policruzadas.

De acordo com a Tabela 5, um mesmo genótipo po derá apresentar diferentes números de raízes, mesmo dentro de uma ärea experimental restrita, como aquela utilizada no presente trabalho. Genótipos com alta produção normalmente apre sentam um nümero de nove raízes bem desenvolvidas (CIAT, 1974). Conforme mencionado anteriormente, o número de raízes poderia ser alterado também em função da população de plantas por ärea. Os limites de variação apresentados na Tabela 4 in dicam amplas possibilidades de sucesso com seleção para maior número de raízes por planta.

h. Produsão de raizes

A produção de raízes entre os progenitores va- 
riou de 1,907 a $12,167 \mathrm{~kg} / \mathrm{planta}$, com média igual a 6,559 kg/ planta; entre as progênies policruzadas esta variação foi de 1,135 a $12,984 \mathrm{~kg} / \mathrm{planta}$, com média igual a $5,289 \mathrm{~kg} / \mathrm{planta}$. Entre os progenitores podem ser distinguidos três grupos: no primeiro seriam incluídos os genôtipos com maior produção de raizes, quais sejam, SRT 1099-Taquari, SRT 59-Branca de Santa Catarina e IAC 12-829; no segundo grupo estariam os genötipos com produção intermediäria, IAC $-14=18$, SRT 1198-Engana Ladrão e IAC 105-66-Caapora; o terceiro grupo compreenderia os genótipos com produções inferiores, ou seja, SRT 1-Vassourinha e SRT 1105-Mico. Entre as progênies policruzadas os genótipos que manifestaram menor produção de raízes foram IAC 12-829 e SRT 1-Vassourinha; as progênies com produções superiores foram os genótipos SRT 1099-Taquari e SRT 1105-Mico; as progênies dos demais genötipos mostraram valores intermediários de produção. A amplitude média para produção de raízes foi $7,218 \mathrm{~kg} / \mathrm{planta}$ entre progenitores e $9,620 \mathrm{~kg} / \mathrm{planta}$ entre progênies policruzadas.

Estes resultados comprovam a excelente adaptação desta cultura a solos ácidos e de baixa fertilidade, conforme se verifica pelas elevadas produções mëdias de raízes observadas para progenitores $(6,559 \mathrm{~kg} / \mathrm{planta}$ ou $21,863 \mathrm{t} / \mathrm{ha})$ e para progênies policruzadas $(5,289 \mathrm{~kg} / \mathrm{planta}$ ou $17,630 \mathrm{t} /$ ha), obtidas durante um pexíodo experimental de dez meses.Tam bém existe a possibilidade de se praticar seleção dentro das progênies policruzadas. De acordo com a Tabela 5, foram ob- 
servados genôtipos produzindo até $12,983 \mathrm{~kg} / \mathrm{planta}$ ou $43,3 \mathrm{t} /$ ha. Tal nivel de produtividade-ê bastante significativo, superando en $50 \%$ o progenitor mais produtivo (SRT 1099 - Taquari $8,660 \mathrm{~kg} / \mathrm{planta}$ ou $28,9 \mathrm{t} / \mathrm{ha}$, Tabela 3). Este fato, indica o grande potencial da população formada pelas progênies policru zadas para o meihoramento da mandioca.

E importante salientar que esta pesquisa não utilizou nenhuma adubação, tendo a mesma sido conduzida em so 10 ácido e pobre em fósforo (Apêndice 2). Níveis de produção tão elevados como os observados neste estudo só ocorrem em plantios comerciais, na região, quando o ciclo vegetativo é estendido para 16 a 24 meses. Tal fato indica o excelente po tencial produtivo aliado à desejável precocidade dos genótipos utilizados. As altas produções de raízes observadas também são consequência das condições ambientais (temperatura e precipitação) plenamente favoráveis que ocorreram durante o período experimental (Apêndice 2).

Observando a ampla variação da produção de raí zes pode entever-se o sucesso da seleção para aumentar a pro. dução de raízes em mandioca, por unidade de área. Salientou -se, nesse contexto, o genótipo SRT 1099-Taquari, por ter apresentado o maior nîvel de proảução de raízes e transmitido esta alta capacidade produtiva para suas progênies policruzadas $(8,660 \mathrm{~kg} / \mathrm{planta}$ ou $28,867 \mathrm{t} / \mathrm{ha}$ e $6,113 \mathrm{~kg} /$ parcela ou $20,377 \mathrm{t} / \mathrm{ha}$, respectivamente). 
.58 .

i. Caracteres em conjunto

Com base nas Tabelas 4 e 5 constatou-se a exis tência de maiox amplitude de variação nas progênies policruza das que entre os progenitores, para todos os caracteres em es tudo. De acoráo com a Tabela 3, as médias dos progenitores foram superiores para altura da planta, diâmetro da planta, peso da p. aérea e produção de raízes, e, inferior para altura da primeira ramificação. No que concerce ao indice de colheita, distribuição de raízes e número de raízes, foram observados valores semelhantes para progenitores e progênies policruzadas.

Ainda na Tabela 3 , observou-se que o progenitor IAC 105-66-Caapora apresentou valores classificados como altos para os caracteres altura da primeira ramificação, altura da planta, diâmetro da planta e peso da p. aérea e, consequentemente, um indice de colheita relativamente baixo. 0 referido genótipo classificou-se como intermediário para os caracteres distribuição de raízes, número de raízes e produção de raízes.

Os genótipos SRT 1-Vassourinha e SRT 1105-Mico, em termos gerais, manifestaram menor altura da primeira ramificação, altura da planta, diâmetro da planta, peso da p. aérea e, consequentemente, maior indice de colheita; não apresentaram, porém, comportamento adequado à distribuição de raí zes, além de possuírem número de raízes relativamente baixo e, consequentemente, os mais baixos valores de produção.

O progenitor SRT 1099-Taquari e respectivas 
progênies policruzadas apresentaram, no geral, valores relat vamente altos para a altura da primeira ramificação, altura da planta, diâmetro da planta e peso dá p. aérea, assim como valores intermediărios para o indice de colheita, melhor distribuição de raízes, maior nümero de raízes e, consequentemen te, maior produção de raízes.

Resultados semelhantes foram observados por ACOSTA-ESPINOZA (1983) utilizando progenitores multiplicados por estaca e progênies policruzadas multiplicadas pór sementes.

Com base no comportamento dos genótipos mencio nados, verificou-se a tendência de existir associações entre os caracteres, as quais serão posteriormente discutidas.

4.2. Eficiencia dos policruzamentos e propagação vegetativa

A eficiência de um esquema de policruzamentos depende diretamente da probabilidade igual de participação de todos os genótipos na formação de gametas e na recombinação gênica. Dois eventos podem evidenciā-1a (VELLO, 1977; ACOSTA -ESPINOZA, .1983), a saber: menor variação entre progênies policruzadas e maior variação dentro das mesmas, em comparação com o que se verificou em relação à variação entre e dentro de progenitores. 
$\mathrm{Na}$ presente pesquisa evidenciou-se, de maneira sistemätica para os oito caracteres avaliados, que a menor va riação relativa entre progênies policruzadas pode ser distinguida pela menor magnitude dos quadrados médios entre progênies policruzadas, quando comparados com os quadrados médios entre progenitores, conforme verificado na Tabela 2. Quanto à maior variação relativa dentro de progênies policruzadas, esta pode ser visualizada pelas diferenças quanto às amplitudes de variação constatadas entre progênies policruzadas e entre progenitores, para os oito caracteres considerados (Tabela 2, 4 e 5); as tabelas 6 e 11 tambëm ilustram este fato.

o esquema de policruzamentos ora empregado baseou-se em parcelas de nove plantas individuais e colheita de sementes da planta central. Esta última tinha por função con tribuir com ôvulos (gametas femininos) enquanto que os grãos de pölen (gametas masculinos) seriam provenientes predominantemente das oito plantas circunvizinhas restantes. Cabe destacar, que a ocorrência de protoginia em mandioca (amadurecimento das flores femininas se dả uma a duas semanas antes das masculinas) minimiza a ocorrência de autofecundações assegu rando a eficiência dos intercruzamentos e proporcionando uma recombinação equilibrada.

$$
\text { Supõe-se que o esquema de parcelas com nove }
$$
plantas, realizando-se a colheita de sementes na planta central, tenha oferecido condições favorảveis aos intercruzamen- 
tos, visto que cada progenitor teve como vizinhos todos os ou tros oito progenitores restantes, constituindo-se exceções al gumas poucas falhas observadas nas 16 repetições. 0 referido esquena deve ser ainda mais eficiente no que concerne à recom binação gênica, em comparação com os esquemas parcialmente ba lanceados (WRIGHT, 1965; OLESEN e OLESEN, 1973) e completamen te balanceado (OLESEN, 1976), nos quais cada parcela é consti tuída, normalmente, por uma-ünica planta. Na presença de fathas de planta e de floxescimento não coincidente entre dife rentes genötipos esta vantagem seria ainda mais significativa. Embora com menor intensidade, tal vantagem também seria identificada em relação ao esquema de policruzamentos acompanham do de seleção (VELLO, 1977), onde uma só planta por parcela participa das recombinações, dado que a seleção elimina todas as demais plantas de cada progênie antes do florescimento. Em se tratando de caracteres passiveis de serem selecionados somente após o florescimento, porém, värias plantas, na parcela, participariam da recombinação. O esquema de policruzamentos presentemente utilizado, entretanto, possui o inconveniente de exigir ärea maior de terreno para a produção de determinada quantidade de sementes.

No lote de policruzamentos foi constatada a presença de insetos polinizadores (abelhas e vespas) em quántidades satisfatörias para o estabelecimento normal de intercruzamentos. Convëm ressaltar que o vento pode, igualmente, representar um agente de contribuição para a polinização em 
mandioca (ALBUQUERQUE, 1969; CONCEICAO, 1979). A existência de plantas prolíficas (com muitas flores), além disso, assegu ra, de certo modo, a sincronização do florescimento entre os diferentes genótipos, favorecendo os cruzamentos e a recombinação ao mesmo tempo em que desfavorece a autofecundação e os cruzamentos preferenciais, que poderiam levar à endogamia. Em bora os insetos, particularmente as abelhas, visitem flores concentradas numa pequena ärea, com 1,5 m de diâmetro máximo, a ocorrência indesejävel de autofecundação é evitada, em gran de parte, devido a preferência das plantas por pölen estranho durante a fecundação (FREE, 1970).

Nesta pesquisa, o progenitor IAC 105-66 Caapora não produziu flores femininas, tendo contribuido apenas com pölen para os intercruzamentos. Isto poderia ter prejudi cado os policruzamentos e aumentado a endogamia da população formada pelas progênies policruzadas. E um fato já conhecido que determinados genōtipos de mandioca não tem florescimento normal sob determinadas condições ambientais. A explicação mais simples envolveria a ação de certos genes para esterilidade masculina e/ou feminina, o emprego constante da reprodução assexuada favoreceria a sobrevivência de genes para esterilidade na população, dado que os alelos para florescimento normal não possuiriam nenhuma vantagem seletiva. Genötipos carregando genes para esterilidade poderiam ser mais vigorosos vegetativamente, de maneira tal que a presença de genes para esterilidade poderia atê representar vantagem seletiva 
durante o processo de reprodução vegetativa continuada. Fato res ambientais como luminosidade, fotopexiodo, temperatura, umidade relativa do ar, fertilidade do solo, tamberm poderiam influenciar de alguma maneira o florescimento. Cuidados espe ciais com florescimento poderão vir a ser necessärios em determinados programas de melhoramento.

A magnitude inferior de variação entre progênies e superior dentro de progênies, relativamente aos valores observados para os progenitores, são indicativos de que a técnica de policruzamentos foi eficiente em promover a recombinação gênica entre os progenitores. Evidência no mesmo sen tido, mas em menor intensidade dentro de parcelas, foi obser vado por ACOSTA-ESPINOZA (1983) comparando progenitores propa gados por estacas com progênies policruzadas propagadas por sementes.

Nos quatro experimentos desta pesquisa, tanto progenitores quanto progênies policruzadas foram multiplicados vegetativamente, através de estacas. Este procedimento teria as vantagens de: possibilitar a obtenção de erros experimentais semelhantes entre parcelas para progenitores e para 
progênies policruzadas; tornar mais realística a comparação entre progenitores e progênies policruzadas, uma vez que ambos foram multiplicados através da mesma via reprodutiva, ou seja, vegetativamente por estacas. O uso de propagação vegetativa, em particular, teria a vantagem de permitir a utiliza ção de réplicas perfeitas dos experimentos, favorecendo o con trole das influências ambientais e melhorando a representatividade dos parâmetros estimados. O procedimento em discussão teria a desvantagem de exigir um plantio adicional para, partir de sementes, obterem-se plantas adultas fornecedoras das estacas das progênies policruzadas. Esta desvantagem tor na-se importante quando se considera que um plantio adicional de mandioca representa período mínimo de dez meses.

Quando se comparam os resultados desta pesquisa com aqueles obtidos por ACOSTA-ESPINOZA (1983), verifica- se que a utilização da propagação vegetativa melhorou acen tuadamente a discriminação entre progenitores e progênies policruzadas no que se refere à variação dentro de parcelas, pa ra três (diâmetro da planta, nümero de raízes e produção de raízes) dos cinco caracteres comuns aos dois estudos. A utilização de propagação vegetativa também deverả tornar mais eficiente a seleção baseada nas médias de produção de raízes das progênịes policruzadas, em função da melhor discriminação entre médias e das alterações na ordem de classificação das médias, quando comparada com os resultados baseados na multiplicação por sementes (ACOSTA-ESPINOZA, 1983). 
4.3. Variabilidade dos caracteres

As estimativas de parâmetros genéticos obtidas no presente trabalho foram calculadas a partir de quatro expe rimentos conduzidos num único local e ano agrícola, durante um ciclo vegetativo de dez meses. Assim, existe a possibilidade de tais estimativas terem sido superestimadas, em consequência da inclusão do componente de variação relativa à inte ração genôtipos $x$ ambiente, Os resultados ora alcançados res tringem-se às condições específicas de cultivo de mandioca na região Centro Sul do Brasil. E muito provável, contudo, que algumas das progênies policruzadas identificadas pela manife tação de caracteristicas agronômicas superiores possam apresentar adaptações similares a outros ambientes.

As estimativas de variabilidade obtidas para os diferentes parâmetros genéticos e fenotípicos encontram-se nas Tabelas 6 e 7. Na Tabela 6 são apresentadas as estimativas e erros associados aos seguintes parâmetros: variância am biental dentro de progenitores, variância fenotípica dentro de progênies policruzadas, variância do erro experimental,com ponente quadrático de variação genotípica entre progenitores, variância genética entre progênies policruzadas, variância ge nética aditiva e dominante para os oito caracteres em estudo. $\mathrm{Na}$ Tabela $\dot{7}$ são apresentadas as estimativas dos parâmetros coeficiente de determinação genotípica, coeficiente de herdabilidade, grau médio de dominância e coeficiente genético de 
variação para os oito caracteres estudados. Considerando-se que os policruzamentos foram eficientes em promover a recomb $\underline{i}$ nação gênica, favorecendo a homogeneização das progênies, seria possível admitir que a população formada pelas progênies policruzadas estivesse em equilíbrio de Castle - Hardy - Wein berg, de maneira que as estimativas seriam não-tendenciosas.. $\mathrm{Na}$ realidade, um ünico ciclo de policruzamentos parece não ter sido suficiente para homogenização completa das progênies, uma vez que ainda existem diferenças significativas entre progênies para os oito caracteres (Tabela 2).

Também, convém discutir o tamanho efetivo da população constituida pelas progênies policruzadas. Considerando que as progênies foram obtidas a partir de nove progeni tores de procedências diferentes e que, na melhor das hipóteses cada um desses progenitores é proveniente do cruzamento de duas plantas geneticamente diferentes, o tamanho efetivo da população seria no máximo igual a 18 ( $9 \times 2$ ( 2). Tal tamanho efetivo seria classificado como pequeno, quando comparado com o tamanho mínimo de 32 genótipos, estimados por BAKER e CURNOW (1969). Um tamanho efetivo reduzido a 18 genótipos, restringiria a variabilidade genética da população original e, possivelmente, levaria à fixação muito rápida de alelos favoráveis e desfavorảveis, limitando o progresso genético com se leção a longo prazo.

Pode--se observar nas Tạbelas 6 e 11, a existência de 
.67 .

variação ambiental dentro de parcelas de progenitores com respeito aos oito caracteres em estudo, para os quais as estimativas dos parâmetros sobrepujaram em mais de 15 vezes os respectivos erros associados. As estimativas da variação fenotípica entre plantas dentro de parcelas para progênies po licruzadas obedeceram à mesma tendência para todos os caracte res; comparando-se as estimativas obtidas dentro de parcelas para progenitores e progênies policruzadas, concluiu-se pela superioridade destas-ültimas; esta superioridade $\vec{e}$ explicada pela existência de um componente genético e de um componente ambiental na variação existente dentro de progênies policruzadas, enquanto que toda a variação existente dentro de progenitores. $\vec{e}$ de natureza ambiental. A existência de variação genética dentro de progênies possibilita a prätica de seleção entre plantas das progênies policruzadas, à semelhan ça do que foi relatado por VELLO (1977), VELLO e VENCOVSKY (1982).

As estimativas de variância ambiental dentro de parcelas $\left(\sigma_{\mathrm{d}}^{2}\right)$ foram superiores às estimativas de variância do erro experimental entre parcelas $\left(\sigma_{e}^{2}\right)$. A partir das informações de Tabela 6, foram calculados os quocientes $\sigma_{\mathrm{d}_{\mathrm{p}}}^{2} /$ $\sigma_{e}^{2}$ para os oito caracteres, os quais são relacionados no quadro a seguir apresentado. 


\section{caracteres}

$\theta_{d}^{2} / \theta_{e}^{2}$

altura da primeira ramificação

9,1

altura da planta

3,0

diâmetro da planta

2,8

peso da parte aērea

3,9

indice de colheita

3,6

distribuição de raízes

4,4

nümero de raízes

4,9

produção de raỉzes

4,7

Os quocientes apresentados no quadro anterior poderão ser de utilidade para outras pesquisas, principalmente naquelas que não diṣpõem da estimativa ambiental dentro de parcelas.

Quanto à variação genotípica entre progenitores, verificou-se que as estimativas dos parâmetros sobrepuja ram em aproximadamente duas vezes os respectivos erros associados, para todos os caracteres em estudo; a mesma tendência foi identificada para as progênies policruzadas, para sete dos oito caracteres considerados. Com base no valor do erro associado, a distribuição de raízes seria um caráter com varia ção nula entre progênies. Confirmando o que foi anteriormente discutido (Tabela 2), as estimativas de variância genotípi ca entre progenitores foram superiores às estimativas de va- 
riância genêtica entre progênies policruzadas, sistematicamen te para os oito caracteres (Tabela 6). A recombinação gênica provocada pelos policruzamentos deve ter deslocado parte da variabilidade existente entre progenitores para dentro das progênies policruzadas.

Pela observação da variância aditiva (Tabela 6) pode-se reconhecer a existência de variação genética para sete dos caracteres avaliados, excetuando-se o caráter distri buição de raízes.

As estimativas de variância dominante podem ser consideradas como nulas para três caracteres: altura da planta, peso da p. aërea e índice de colheita. Para os demais cinco caracteres, a variância dominante está presente, chegando atề a superar a variância genêtica aditiva, no caso dos caracteres altura da primeira ramificação, diâmetro da planta, distribuição de raízes e produção de raízes (Tabelá 6). Com base nas magnitudes das estimativas e na relação entre estimativas e erros associados, verifica-se que os resultados apresentados são mais realísticos do que aqueles obti dos por ACOSTA-ESPINOZA (1983). A melhor representatividade das estimativas seria consequência de dois fatos: utilização de propagação vegetativa para multiplicação das progênịes; maior númeiro de plantas envolvidas, em função do grande núme ro de parcelas $(40=10$ repetições $\times 4$ experimentos $)$ e da casualização dessas parcelas por toda a ärea experimental. 
As estimativas dos coeficientes de determinação genotípica (Tabela 7), b, representam medidas da quantida de de variação existente entre os genótipos dos progenitores, ao nivel de plantas individuais, nos diferentes caracteres. A sua validade se restringe ao conjunto de progenitores utiliza dos nesta pesquisa, pois este parâmetro é de natureza fixa. Uma primeira utilidade para o bé a possibilidade que ele ofe rece de comparar a magnitude da variação genotípica existente em diferentes grupos fixos de genótipos, uma vez que ele foi estimado ao nível de plantas individuais, estando portanto livre de efeitos experimentais. Uma segunda utilidade do b é a possibilidade que ele oferece de comparar os niveis de variação existentes em caracteres diferentes, no sentido de se predizer o grau relativo de dificuldade para alterar cada carăter através de seleção. Conforme relatado na revisão de literatura, o b corresponde ao coeficiente de herdabilidade no sentido amplo para um conjunto fixo de genótipos. MARTINS e VELLO (1981) e ACOSTA-ESPINOZA (1983) mencionam que os valores de b podem variar de 0 a 1 , de maneira que conjuntos de genótipos e/ou caracteres possuindo valores de bröximos de 1 são esperados serem mais facilmente alterados por seleção. Este tipo de predição deve ser acompanhado de certo cuidado, pois tanto o b como o coeficiente de herdabilidade no sentido amplo medem a variação genotípica total, incluindo-se as variâncias aditiva, dominante e espistáticas, e nem todas elas são aproveitáveis na seleção. 
De acordo com a Tabela 7 , tendo os valores de b sido superiores aos erros a eles associados, existiria variação genotípica em todos os caracteres. Caracteres como a 1 tura da planta e diâmetro da planta, possuindo valores superiores parab, seriam mais facilmente alterados por seleção; peso da $\stackrel{p}{ }$. aerea, indice de colheita e altura da primeira ramificação, apresentariam grau intermediário de dificuldade à seleção; distribuição, número e produção de raízes seriam caracteres com maiores dificuldades de serem alterados por sele ção.

Resultados contrastantes com os obtidos nesta pesquisa e com aqueles observados por ACOSTA-ESPINOZA (1983) foram encontrados por: BARRIGA (1980) que obteve valores altos de b para produção de raízes $(b=0,52$ a 0,91$)$ e peso da folhagem ( $b=0,91$ e 0,94); DANTAS (1984), para produção de raizes $(b=0,74)$ e. Indice de colheita $(b=0,878)$. Tais diferenças de resultados seriam explicadas, em primeiro lugar, : pelo fato das estimativas de BARRIGA (1980) e DANTAS terem sido obtidas ao nível de médias de repetições, de tal forma que o erro experimental foi reduzido e, em consequência, as estimativas de $\underline{b}$ tornaram-se superiores; o coeficiente de determinação calculado com base em médias de : repetições, tem a desvantagem de ficar restrito ao tipo de experimento que levou à sua obtenção, não podendo ser comparado com estimativas obtidas em experimentos com delineamento ou estru tura diferente. A diferença entre os resultados, deveu-se, 
também, à própria natureza fixa do coeficiente de determinação, limitando a sua validade ao conjunto de genótipos analisados. Além disso, diferenças no ciclo vegetativo e diferenças ambientais entre os locais, anos e práticas culturais tam bẻm poderiam levar à obtenção de valores diferentes para b. De fato, Cock (1982) salientou que as influências de ambiente podem alterar o ciclo vegetativo da mandioca, o qual pode variar de nove a doze meses em regiões quentes, alcançando até 24 meses em regiões mais frias.

A Tabela 7 também relaciona os valores das estimativas dos coeficientes de herdabilidade $\left(\mathrm{H}^{2}\right)$ no sentido restrito e ao nivel de plantas individuais. Estes coeficientes tem natureza aleatória e refletem a magnitude da variância genética aditiva, podendo ser utilizados na predição da resposta.a ser alcançada com a prática de seleção para qualquer carăter da população formada pelas progênies policruzadas. Os valores de $\mathrm{H}^{2}$ tambëm podem ser comparados com aqueles obtidos em outros experimentos, pois estão livres dos efeitos experimentais, uma vez que foram calculados ao nível de plantas individuais.

As estimativas de $\mathrm{H}^{2}$ tendo sido superiores aos erros a elas associadas (Tabela 7 ) indicam a existência de va riação genética passível de ser explorada por seleção nos oito caracteres, Indice de coḷheita foi o caráter com maior $\mathrm{H}^{2}$ e, com maior grau de variação genética. Distribuição e produ 
ção de raizes possuem os menores valores de $\mathrm{H}^{2}$ e, portanto, os menores graus de variação genética. Observa-se na Tabela 7 que os caracteres são ordenados diferentemente em relação aos coeficientes b e $\mathrm{H}^{2}$. Esta diferença de classificação é explí cada pela presença de variância dominante e das epistasias a ela associadas no numerador do b, e à ausência das mesmas no numerador de $\mathrm{H}^{2}$.

Embora com magnitudes diferentes, as estimativas de $\mathrm{H}^{2}$ tem a mesma ordem de classificação nesta pesquisa e naquela conduzida por ACOSTA-ESPINOZA (1983), para os cinco caracteres comuns aos dois estudos. Os valores de $\mathrm{H}^{2}$ da presente pesquisa devem ser mais realísticos, pelas razões jä discutidas, envolvendo propagação vegetativa, maior nưmero de plantas $(120=4$ experimentos $\times 10$ repetições $\times 3$ plantas $/$ par cela) e maior período experimental (dez contra oito meses).RA MALHO e PEREIRA (1979) mencionam valor de $\mathrm{H}^{2}=0,475$ para pro dução de raízes de mandioca; como esta herdabilidade foi esti mada com base em médias, ela não deve ser comparada com valores obtidos em outros experimentos.

Com base nos valores de grau médio de dominância (gmd) apresentados na Tabela 7, os oito caracteres seriam assim caracterizados, quanto ao tipo de ação gênica predominante na hèrança:

- ação gênica aditiva: Indice de colheita; 
- dominância parcial: número de raízes, peso da parte aérea e altura cia planta;

- sobredominância: diâmetro da planta, produção de raízes, altura da primeira ramifica ção, distribuição de raízes.

ACOSTA-ESPINOZA (1983) obteve resultados semelhantes de gmd para três caracteres: altura da planta, diâmetro da planta e indice de colheita; mas, obteve resultados contrastantes para dois caracteres: número de raízes e produção de raízes. Novamente, convém salientar a melhor represen tatividade das estimativas obtidas na presente pesquisa, em função do uso de propagação vegetativa, maior número de plantas e maior periodo experimental.

As estimativas de coeficiente genético de variação $\left(\mathrm{CV}_{\mathrm{g}}\right)$ também foram relatados na Tabela 7 . Sendo o $\mathrm{CV}_{\mathrm{g}}$ o quociente entre o desvio padrão genético e a mêdia do caráter, ele indicaria a amplitude das diferenças genéticas obser vadas no caräter, independentemente da unidade de avaliação do caráter. Valores altos de $\mathrm{CV}_{\mathrm{g}}$ indicariam existência de ge nótipos mais extremos (trangressivos); valores de $\mathrm{CV}_{\mathrm{g}}$ próximos de zero indicariam falta de variabilidade genética, ou, concentração de genötipos em torno da média do caráter. Com base nos vaiores de $\mathrm{CV}_{\mathrm{g}}$ da Tabela 7 , haveria maiores possibilidades de selecionar genótipos transgressivos para os caracteres peso da p. aérea, altura da primeira ramificação e pro- 
dução de raízes; mudanças relativamente intermediärias poderão ocorrer nos caracteres: Indice de colheita, altura da planta, diâmetro da planta e nümero de raízes; finalmente, o caráter distribuição de raízes dificilmente será alterado por seleção.

Com base no conjunto de parâmetros relatados, os seguintes procedimentos seriam mais indicados para melhora mento dos oito caracteres:

a altura da primeira ramificação: hibridação a curto prazo e seleção a longo prazo;

b. altura da planta: seleção ou hibridação;

c. diâmetro da planta: hibridação a curto prazo e seleção a longo prazo;

d. peso da p. aêrea: seleção recorrente e hibridação;

e. Indice de colheita: seleção;

f. distribuição de raízes: alteração muito difícil, com chances em programas de hibridação;

g. nümero de raízes: seleção recorrente;

h. produçãa de raĩzes: hibxidação a curto prazo e seleção recorrente a longo prazo.

Do resumo anterior, dois fatos são relevantes: 
o primeiro compreende a importância de se utilizar o índice de colheita nos programas de seleção para maior produtivida de; o segundo fato, compreende a possibilidade de se conseguir sucesso para os caracteres de valor econômico, como produção de raízes, altura da primeira ramificação e diâmetro da planta, em programas de hibridação. Esta possibilidade é enriquecida pela relativa facilidade com que a heterose pode ser fixada e multiplicada através da reprodução vegetativa, via normal de multiplicação comercial da mandioca.

As estimativas de variância dominante e grau médio de dominância estão concordantes com a mencionada (ALLARD, 1971) existência de grande quantidade de heterozigosida de nas espécies que utilizam propagação vegetativa para multí plicação comercial.

De acordo com o que foi relatado na revisão de literatura, a condição de espécie monóica, altamente prolífica, com flores de tamanho adequado para fäcil manipulação,tan to em autofecundações, como em cruzamentos, e a possibilidade de se empregar propagação vegetativa e macho-esterilidade, tor nam viảvel a aplicação de praticamente todos os métodos exis tentes, em programas de melhoramento da mandioca.

Em função do ciclo vital longo, com um mínimo de dez meses para colheita das raízes comerciais, e da dificuldade de avaliação da produção de raízes, torna-se importan te conhecer as associações entre os diferentes caracteres, 
principalmente entre os caracteres da parte aérea e a produção de raízes. Talvez, existam caracteres da parte aêrea que possam ser üteis para avaliação indireta da produção de raízes.

4.4. Associacões entre os caracteres

As associações entre os caracteres foram pesquisadas utilizando-se as observações experimentais das progê nies policruzadas, através das estimativas de correlações entre os caracteres combinados dois a dois (Tabela 8) e das equações lineares mültiplas envolvendo produção de raízes e os demais caracteres (Tabela 9). Estimativas de soma de produtos, produtos médios e covariâncias entre os caracteres estão na Tabela 10 .

Na Tabela 8 são apresentados os coeficientes de correlação fenotípica, genética e experimental, dos caracteres combinados dois a dois, O termo coeficiente de correla ção experimental foi preferido em substituição ao termo corre lação ambiental, pelas razões expostas em materiais e métodos.

Em geral, os valores de correlações fenotípicas e genéticas foram muito semelhantes entre si; isto é explicado pelo fato das correlações fenotípicas terem sido esti madas ao nível de mèdias de progênies, minimizando a influên- 
cia ambiental e tornando os dois tipos de correlação muito se melhantes em valor. Tendência semelhante é relatada por RAMA LHO e PEREIRA (1979).

Com algumas excessões, a correlação experimental mostrou-se inferior às correlações fenotípicas e genéti cas.

Os maiores valores (próximos da unidade) de correlação fenotípica e genética foram observados entre os ca racteres distribuição, número e produção de raízes, indicando que sistema radicular com grande número de raízes, distribuídos em circunferência ao redor da inserção da estaca original, devem maximizar a produção de raízes.

Diâmetro da planta foi o caráter da parte aêrea que mais fortemente se correlacionou com produção de raízes, exibindo valores acima de 0,5 para os três tipos de correlação considerados. Este equilíbrio entre os tipos de correlação está indicando que diâmetro da planta e produção de raízes são dois caracteres correlacionados geneticamente (pleiotropia e/ou ligação gênica) e, tambẻm, ambientalmente , ou seja, mudanças ambientais tem reflexos comuns nos dois caracteres.

As correlações dos caracteres altura da planta e Indice de colheita com produção de raízes representam situa ção desfavorável ao melhoramento, pois, as correlações fenotí pica e genética são baixas, mas a correlação experimental è 
intermediária. Portanto, qualquer indício de associação de altura da planta e indice de colheita com produção de raízes teria razões muito mais ambientais do que genéticas.

Embora peso da p. aërea e índice de colheita. tenham altos valores de correlação fenotípica e genética entre si $(r>-0,85)$, as correlações de ambos com produção de raízes são bem inferiores $(r<0,40)$. Tal fato tem aspecto positivo, pois indica a possibilidade de se obterem genótipos com alta produção de raízes e limitado crescimento vegetativo. Estes genōtipos teriam eficiência fotossintētica superior e permitiriam a redução dos espaçamentos utilizados nos plantios comerciais.

Mais importante que o estudo das correlações entre os caracteres combinados dois a dois, seriam os estudos relativos às associações mủltiplas entre caracteres.

Na Tabela 9 são apresentadas as equações de re gressão linear mủltipla entre o carăter produção de raízes ( $Y$ = variável dependente) e os demais sete caracteres pesquisan dos, como variáveis independentes $\left(x_{1} a x_{7}\right)$. Nestas equações, os valores de $b_{1} a b_{7}$ representam coeficientes de regressão parcial, de maneira que eles medem a associação entre um determinado caráter e produção de raízes, ajustadas pa ra os demais caracteres. O coeficiente de determinação $\left(R^{2} \frac{q}{o}\right)$ que acompanha cada equação indica a porcentagem da variação observada na produção de raízes, que é explicada pela equação 
de regressão linear múltipla.

A equação no 127 da Tabela 8, que incluiu todas as sete variâveis independentes, explicou $86^{\circ}$ da variação observada na produção de raízes. Outros caracteres, não incluidos nesta pesquisa, devem ser responsáveis pelos restantes $14 \%$ não-explicados por esta equação.

Do total de 127 equações apresentadas na Tabela 9 , existem 31 equações com $\mathrm{R}^{2}>80 \%$. A mais simples dessas equações é aquela de $n \circ 23\left(R^{2}=83 \%\right)$ na qual são incluidos apenas dois caracteres: peso da p.aérea e índice de co1heita. A adição de mais caracteres só melhorou a representa tividade da equação em $3 \%$ (equação $n \circ 127, \mathrm{R}^{2}=86 \%$ ). Portan to, peso de p. aérea e indice de colheita em conjunto são os caracteres mais importantes para estimação da produção de raí zes.

Considerando-se os quatro caracteres da parte aérea, $x_{1}=$ altura da primeira ramificação, $x_{2}=$ altura da planta, $x_{3}=$ diâmetro da planta e $x_{4}=$ peso de p.aérea, obte ve-se a equação n! 64 com $R^{2}=58 \%$. Portanto, os caracteres da parte aérea em conjunto explicam no máximo $58 \%$ da variação observada na produção de raízes, A equação no $44\left(R^{2}=58 \%\right)$ é função de três caracteres da parte aérea: altura da planta, diâmetro da planta e peso da p. aérea. Comparando-se as equa ções nọs 44 e 64, observa-se que a retirada do caráter altura da primeira ramificação não trouxe nenhum prejuízo à equação. 
Comparando-se as equações nọ 64 e nọ 34, verifica-se que a re tirada da altura da planta provocou um prejuizo de apenas $1 \%$ à equação. A retirada simultânea dos dois caracteres altura da primeira ramificação e altura da planta, prejudicou a equa ção em apenas 1\% (comparar equações nọs 64 e 19). Finalizando, os caracteres diâmetro da planta e peso da parte aérea são os caracteres da parte aérea mais importantes para a predição da produção de raízes. Individualmente, diâmetro da planta contribui com 44\% (equação no 3), peso da parte aérea com $49 \%$ (equação no 4); em conjunto, esses dois caracteres contribuem com 57\% (equação nọ 19) para explicar a variação observada na produção de raízes.

Estudos realizados por ESTEVÃO et alii (1972) mostraram que o peso da ṕ. aérea foi o único carāter que contribuiu significativamente para a produção de raízes. Já SIL VA (1977) observou que altura da planta, diâmetro da planta e peso da p. aérea. foram os caracteres que mais contribuiram pa ra a produção de raízes.

Com as informações disponíveis, värias alterna tivas podem ser esquematizadas para um processo de predição da produção de raízes (y em $\mathrm{kg} / \mathrm{planta}$ ). A alternativa mais simples estaria baseada em um ünico caräter, o diâmetro da planta $\left(X_{3}\right.$ em metros), Para esta alternativa, a equação 3 forneceria :

$$
y=-2,992+4,843 x_{3} \quad\left(R^{2}=44 \%\right)
$$


Uma segunda alternativa envolveria os caracteres diâmetro da planta e peso da r. área. Neste caso, haveria necessidade de se cortar o caule e anotar o peso fresco da parte ĭërea em kg/planta. A equação nọ 19 explicaria:

$$
y=1,427+2,659 x_{3}+0,520 x_{4} \quad\left(R^{2}=57 \%\right)
$$

Observandonse a Tabela 9 verificasse que para aumentar significativamente o $R^{2}$ hä necessidade de se incluir o Indice de colheita. Neste caso, seria preciso colher a planta, separar a parte aérea e subterrânea para obtenção do índice. Assim sendo, não haveria interesse prático em se pre dizer a produção de raízes, pois o seu valor já estaria deter minado.

Maior valor de índice de colheita implicaria em parte aérea menos vigorosa e, consequentemente, em menor número de estacas por planta. O valor do índice de colheita não poderia ser muito alto, para não comprometer a multiplicação vegetativa necessária para atender aos novos plantios comerciais. A utilidade do índice de colheita estaria mais limitada aos programas que tivessem por objetivo a obten ção de genötipos com arquitetura apropriada para plantios com alta densidade populacional de plantas, na procura de maior rendimento de raízes por unidade de ärea. Sob alta densidade populacional, o nưmero maior de plantas por unidade de ärea compensaria o menor crescimento da parte aẻrea, de maneira 
que a produção de estacas seria normal. Em tal situação, os dois objetivos principais estariam atendidos: maior produção de raízes por unidade de área e produção de estacas em quantí dade satisfatöria para atender novos plantios comerciais.

Algumas sugestōes podem ser oferecidas para me lhorar a predição da produção de raízes, a saber:

a. Estabelecer critério apropriado para avaliação do peso da p. á́rea através de um sistema de notas visuais, no sentido de se evitar o corte da planta e a pesagem da parte aérea; tais notas visuais poderiam, inclusive, substituir o peso da parte aérea para o cảlculo mais simples do ínàice de colheita;

b. Incluir outros caracteres da parte aérea, não pesquisados neste estudo, e que também possam contribuir para explicar parte da produção de raízes; poderiam ser mencionados: número de ramos, nümero de ramificações, altura da planta em idades diferentes de desenvolvimento, diâmetro do caule; data de florescimento; número de flores; data da primeira ramificação;

c. Estabelecer diferentes pesos relativos para os caracteres, na tentativa de se encontrar um indice global que estime melhor a produção de raízes por unidade de ảrea, ou seja, o rendimento. 
.84.

\section{CONCLUSOES}

Os resultados discutidos permitem as seguintes concluções relativas aos genótipos de mandioca estudados:

a. Distribuição de raízes mostrou variabilidade quase nula e dificilmente pode ser alterada por seleção.

b. Indice de colheita, altura da planta, peso da parte aérea e nümero de raízes exibiram níveis de variabilidade suficien tes para a obtenção de progressos por seleção.

c. Altura da primeira ramificação, diâmetro da planta e produ ção de raízes mostraram-se mais promissores para programas de hibridação visando-se exploração do vigor de híbrido.

d. Distribuição, nümero e produção de raízes foram os caracte res com os maiores valores de correlações fenotípicas e ge nëticas entre si. 
e. Produção de raízes foi melhor explicada pela combinação de peso da p. aérea e índice de colheita.

f. Peso da p.á̉rca e diâmetro foram os caracteres da parte aérea mais correlacionados com produção de raízes.

g. Altura da primeira ramificação foi o único carảter que apresentou tendência de correlação negativa com produção de raízes.

h. Magnitude da variabilidade e grau de associação com outros caracteres indicaram ser o indice de colheita de muita uti lidade nos programas de melhoramento para maior produtividade de raízes.

1. O genótipo SRT 1099-Taquari destacousse pela elevada produ ção de raízes e por ter transmitido alta capacidade produtiva à sua progênie policruzada, fatos indicadores deste genötipo possuir alta frequência de alelos favorảveis à produção de raízes.

j. A existência de genótipos com produção de raízes ao nível de $43,3 \mathrm{t} / \mathrm{ha}$ ( $50 \%$ superior ao melhor progenitor) indicou a potencialidade da população formada pelas progênies policruzadas, como fonte de material melhorado.

k, o emprego combinado de policruzamentos e propagação vegetativa constituiu-se em procedimento apropriado para estimação de parâmetros que avaliam variabilidade e associam 
.86.

ções genëticas e fenotípicas entre caracteres durante síntese de uma população melhorada de mandioca. 


\section{LITERATURA CITADA}

ACOSTA, J.E., 1978. Estudios preliminares sobre el cultivo de la yuca (Manihot esculenta Crantz) en el Estado de Yuca tān. Satillo Coahuila, México, UAAAN. 143 p. (Tese. de Graduación).

ACOSTA, J.E., 1978a, Yuca. In: CERVANTES SANTANA, T. ed. Recursos genéticos disponibles a Mexico. Chapingo, Socie dad Mexicana de Fitogenetica A.C. - p. 139-143.

ACOSTA, J.E., 1979. Informe de labores. Huimanguillo, Tabas CO, INIA/CÍAGOC/CAEHUI .

ACOSTA-ESPINOZA, J., 1983. Eficiência de policruzamentos para recombinação gênica e estimação de parametros genéticos em mandioca (Manihot esculenta Crantz). Piracicaba, ESALQ/ USP, 79 p. (Dissertação de Mestrado). 
ACOSTA-ESPINOZA, J., N.A. VELLO, P.S. MARTINS, J.O. LORENZI e E.S. NORMANHA, 1982. Síntese de uma população melhorada de mandioca (Manihot esculenta Crantz). Relatório Cientifico do Departamento de Genética, ESALQ/USP. Piracicaba, n! 16 .

AJUDARTE NETO, F. , 1979. Seleção dentro de progênies de couve-brócolos ramosa de inverno (Brassica oleracea L. var, italica Plenck). Piracicaba, ESALQ/USP, 108 p. (Tese de Doutoramento).

AlBUQUERQUE, M., 1969. A mandioca na Amazōnia, Belém, Pará. SUDAM, $277 \mathrm{p}$.

ALLARD, R.W., 1971. Principios de melhoramento genético das plantas. São Paulo, Edgard Blücher. 381 p.

ALMEIDA, F.C.G., R. de P. NUNES e F.E.C. NUNES, 1976. Produção de raízes de mandioca (Manihot utilissima Poh1.) em re gime de suplementação hídrica e suas relações com produção de ramas. Ciência Agronōmica. Fortaleza, 6: 31-34.

ANSTEY, T.H., 1954. Self-incompatibility in green sprouting brocoli (Brassica oleracea L. var. italica Plenck). I. Its ocorrence and possible use in a breeding program. Canadian Journal of Agriculture Science. Ottawa, 34: 59$-64$. 
BAKER, L.H. e R.N. CURNOW, 1969. Choice populations size and use of variation between replicate populations in plant breeding selection programs. Crop Science. Madison, 9: 555-560.

BARRIGA, R.H.M.P., 1980. Caracterização de cultivares de man dioca (Manihot esculenta Crantz) com relação à produção e estabilidade. Piracicaba, ESALQ/USP, 129 p. (Dissertação de Mestrado).

BELLOTI, A.C., J.A. REYES, B. ARIAS e O. VARGAS, 1982. Insec tos y acaros de la yuca y su control. In: DOMINGUES, C.E. Yuca investigación, producción y utilización. Cali, PNUD/ CIAT. Cap. IV, p. 367-392,

BIRADAR, R.S., P.G. RAGENDRAN e N. HRISNI, 1978. Genetic variability and correlation studies in cassava (Manihot esculenta Crantz). Journal of Root Crops, New York, 4: 7-10. Apud, Resumenes Analiticos sobre yuca (Manihot esculenta, Crantz) CIAT 1980 , V. VI, p. 123.

BOX, G.E.P., 1954. Some theorens on Quadratic Forms Applied in the Study of Analysis of Variance Problems, I. Annals Mathematical Statistics, Ann Arbor, 25: 209-302.

CARLSON, I.T., 1971. Randomness of mating in a polycross of orchardgrass, Dactylis glomerata. Crop Science. Madison, 11: 499,502 . 
CENTRO INTERNACIONAL DE AGRICULTURA TROPICAL, 1974. Informe Anual, Cali, p. 58-118.

CENTRO INTERNACIONAL DE AGRICULTURA TROPICAL, 1975. Informe Anual, Cali, p. B-1-B-63.

CENTRO INTERNACIONAL DE AGRICULTURA TROPICAL, 1978. Informe Anual, Cali, p. A-1-A-110.

CESNIK, R., 1972. Estudo da herdabilidade de alguns caracteres em cana-de-açúcar. Piracicaba, ESALQ/USP, 78 p. (tese de Doutoramento).

CHANDRARATNA, M.F. e K.D.S.S. NANAYAKKARA, 1948, Studies in cassava. II. The production of hybrids. Tropical Agriculturist, Peradenyra, 104: 59-74.

COCK, J.H., 1978. Potencial agronomico para la producción de yuca. In: CENTRO INTERNACIONAL DE AGRICULTURA TROPICAL. Curso de producción de yuca, Cali, Colombia, CIAT, v. 1. p. $31=39$.

COCK, J.H,, 1982, Aspectos fisiologicos del crescimiento y desarrollo da planta de yuca, In: DOMINGUEZ, C.E. Yuca investigación produceiōn y utizización. Cali, PNUD/CIAT. Cap. I, p. $51-74$.

CONCEIÇÃO, A.J. da, 1979. A mandioca. Cruz das Almas, UFBA/ EMBRAPA/BNB/BRASCAN/NORDESTE, $382 \mathrm{p}$. 
DANTÁS, J.L.L., 1984. Potencialidade de genotipos de mandioca (Manihot esculenta Crantz) para programas de seleção no reconcavo Baiano. Piracicaba, ESALQ/USP, 105 p. (Dissertação de Mestrado).

DAYAL, T.R., M.D. UPADHYA, V.P. MALHOTRA e K.L. MEHRA, 1972. Heritability and correlation in yield and other quantitative characters in potato (Solanum tuberosum L.). Indian Journal Agricultural Science, Dehhi 42(6): 464-466.

DOMINGUEZ, C.E., L.F. CEBALlOS e C. FUENTES, 1982, Morfologia da planta de yuca, In: DOMINGUEz, C.E. Yuca investigación produción e utilización. Cali, PNUD/CIAT, Cap. I p. $27-49$.

DRAPER, N. e H. SMITH, 1966. Applied regression analysis. New York. John Wiley e Sons Inc, p. 163-262.

ESTEVAO, E, de M., J.C.E.O. BEGAZO, S.S. BRANDÃO e L.M. OLIVEIRA, 1972. Produção de raízes e ramas é relação entre caracteres da parte aérea e produção de raízes em variedades de mandioca. Revista Ceres, Viçosa, 19: 311-327.

FALCONER, D.S., 1981. Introduction Quantitative Genetics. 2 a ed. New York, Logman Am. 340 p.

FAO PRODUCTION YEARBOOK, 1982. Rome v. 36 p. 127-128. (FAO statistics series, no 49). 
FONSECA, T.C., 1978, Estimação de parametros visando a seleção de híbridos artificiais da amoreira (Monusalba L.). ESALQ/USP. 51 p. (Dissertação de Mestrado).

FREE, J.B., 1970. Insect pollination of crops. London, Academic Press. 544 p.

FREEMAN, G.H., 1967. The use of cyclic balanced incomplete block designs for directional seed orchards. Biometrics, Raleigh, 23: $761-778$.

FUKUDA, W.M.G., 1979, Produção e seleção preliminar de novos híbridos de mandioca (Manihot esculenta Crantz). Congresso Brasizeiro de Mandioca. Cruz das Almas, BA, Barsil, 1: $535-545$,

FUKUDA, W.W.G., H.W.L. de CARVAlHO, S, de O. e SILVA e R.C. CALDAS, 1983. Avaliação de clones de mandioca no Centro Nacional de Pesquisa de Mandioca e Fruticultura, Revista Brasileira de Mandioca. Cruz das Almas, 2: 1-7.

GAUR, P.C., KISHORE e P.K. GUPTA, 1978. Studies on character association in potatoes. The Journal of Agricultural Science, London, 90 (part 1): 215-219..,

GOMES, G., J. SANTOA e M. VALDIVIESO, 1982. Utilización de raízes y productos de yuca en alimentación animal. In: DOMINGUES, C.E. Yuca investigación producción y utilización. Cali Colombia PNUD/C/AT. Cap. V, p. 539-566. 
GOWERS, S., 1974. The production of $\mathrm{F}_{1}$ hibrid sweeds (Brassi ca napus spp rapiferal by the utilization of self-incompa bility. Euphytica. Wageningen, 23: 205-276.

GRANER, E.A., 1942. Genëtica de Manihot. I, Hereditariedade da forma da folha e da coloração da película externa das raizes em Manihot utilissima Pohl. Bragantia. Campi nas, $2(1): 13-22$.

GRANER, E.A., 1942a. Notas sobre florescimento e frutificação da mandioca. Bragantia, Campinas, 2(1): 1-12.

GRANER, E.A., 1942b, Tratamento de mandioca pela colq̨uicina. Bragantia, Campinas 2(2): $23-54$.

GRANER, E.A., 1946. Tratamento de mandioca pela colquicina. Anälise comparativa entre clones diplöides e tetraplöides. Anais da Escola Superior de Agricultura "Luiz de Queiroz", Piracicaba, v. 3, p. 99-140.

GULICK, P., C. HERSHEY e J, ESQUINAS ALCAZAR, 1983. Genetic Resources of Cassava ana Wild Relatives, Rome, International Bornd for Plant Genetic Resources, $50 \mathrm{p}$.

GUTIERREZ, M.G. e G.F. SPRAGUE, 1959. Randomness of mating in isolated polycross plantings of maize, Geneties. Austin, 44: $1075-1082$. 
HAHN, S.K. e E. TERRY, 1973. Cassava breeding at IITA. In: DOMINGUES, C.E. Yuca: investigación, producción y utizización. Cali, PNUD/CIAT, 1982. Apud Hershey, C. e AMAYA, A. Genetica, citogenetica, estructura floral y tecnicas de hidridacion de 1a yuca. Cap. II, p. 113-126.

HAHN, Ka, K. HOWLAND e R. TERRY, 1980. Correlated resistance of cassava to mosaic and bacterial blight diseases Nigeria. Euphytica. Wageningen, 29: 305-311.

HANSON, W.D., 1963. Heritability. In: HANSON, W.D. e H.F. ROBINSON, Ed., statistical Geneties and Plant Breeding. Washington, National Academic Science - National Research Council, p. $125-139$.

HEEMSTRA, S., 1955. The use of vegetative reproduction in the breeding of cross fertilizing plants. Euphytica. Wageningen, 4 : $227-229$.

HERSHEY, C. e A. AMAYA, 1982. Genética, citogenëtica, estrutura e técnica de hibridação de la yuca. In: DOMINGUEz, C.E. Yuca investigación producción y utilización. CaIi PNUD/CIAT. Cap. II, p. $113=126$.

HOLGUIN, F.M., M.A.L. URIAS, J.E. ACOSTA, V.W.L. GONZALEZ, F. A.L. IBARRA, A.R. MENDEZ, F.C. OCHOA, L.A. PASTRANA, P.B. RUIZ e J.P. VILALOBOS, 1981. Sabanera y costeña dos nuevas variedades de yuca para el tropica humedo de México. Huinanguillo, Tabasco, INIA/C IAGOC/CAEHUI. 9 p. (Folheto técnico, 1). 
INSTITUTO BRASILEIRO DE GEOGRAFIA E ESTATISTICA, 1957. Enciclopédia dos municipios brasizeiros. Rio de Janeiro, v. $28, \mathrm{p}, \quad 57-58$

JENNINGS, D.J., 1970. Cassava in Africa Apud Field crops abstracts, Famkam Royal 23(3): 271-278.

JOS, J.S, e N. HRISHI, 1976. Inheritance of leaf shape in cassava. Journal Foot crops, Truvandrum, 2: 10-12.

KAWANO, K., 1980. Cassava. In: Hybriaization of Crop Plants. Madison, American Society of Agronomy. Cap. 13, p. 225$-233$

KAWANO, K., 1982. Mejoramiento genëtico de yuca para productividad. In: DOMINGUEZ, C.E. Yuca investigatión producción y utizización. Cali, PNUD/CIAT. Cap. II, p. 91-112.

KAWANO, K, A. AMAYA, P. DAZA e M, RIOS, 1978. Factors afeecting efficiency of hybrization and seleciton in cassava, Crop Science, Madison, 18: 373-376.

KNOWLES, R.P., 1969. Nonrandom pollination in polycrosses of smooth bromegrass, Bromus inermis Leyss. Crop Science. Madison, 9: $58-61$.

LOZANO, J,C: e R.H. BOOTH, 1982, Enfermedades de Ia Yuca. In: DOMINGUEZ, C.E., yuca investigation producción y utilizaeción. Cali, PNUD/CIAT. Cap. IV. p. 421-461. 
MAITY, S. e B.N. CHATTERJEE, 1977. Growth attibrutes of potato and their interrelationship with yield. Potato Research Wageningen, 20: 337-41.

MARIS, B., 1969. Studies on maturity, yield, under water weight and sonse other characters of potato progenies. Euphytica Wageningen, 18: 297-319.

MARTINS, P.S. e N.A. VELLO, 1981. Performance and variability of agronomic characters in population of stylosantes guaíanensis (Aubl.) Sw. In: SMITH, J.A. e V.W. HAYS. INTERNATIONAL GRASSLAND CONGRESS, 14, Kentucky, 1981. Proceedings. p. $15-24$.

MATTOS, P.L.P. de, J.M.M: SAMPAIO e R.C. CALDAS, 1980. Compe tição de cultivares de mandioca (Manihot esculenta Crantz) no municipio de Santa Terezinha - Bahia. Cruz das Almas, EMBRAPA/CNPMF. $6 \mathrm{p}$. (sërie comunicado tëcnico no 12). MENDES, C.T., 1940. Contribuição para o estudo da mandioca. São Paulo, Secretaria de Agricultura e Comércio do Estado de São Paulo. $88 \mathrm{p}$.

MILLER, J.D. e N.I. JAMES, 1974. The influence of stalk density on cane yield, Proceedings of the International Society. of Sugar cane technologists, 15: 177-184. 
NESTEL, B., 1978. Utilização actual y: potencial futuro de la yuca, In: Curso de Producción de Yuca. Cali, CIAT, v. 1, p. $1-29$.

NIEUWHOF, M., 1963, Pollination and contamination of Brassica oleracea L. Euphytica, Wageningen, 12: 17-26.

NIEUWHOF, $M_{4}, 1968$. Possibilities of incompletely sib-incompatible inbred lines in breeding hybxid varieties of cole crops (Brassica oleracea L.). Euphytica, Wageningen, 17: $3-10$.

NIEUWHOF, M., 1969. Coze crops, London, Leonard Hill, 353 p. (World Crop Books).

NORMANHA, E.S., 1971. O trabalho de melhoramento de mandioca do Instituto Agronômico do Estado de São Paulo. O Agronômico. Campinas, 23: $91: 100$.

NORMANHA, E.S, e A.S. PEREIRA, 1964. Cultura da mandioca. Boletim. Instituto Agronómico de Campinas, n. 124. 29 p.

OLESEN, K., 1976. A completely balanced polycross design. Euphytica. Wageningen, 25: 485-488.

OLESEN, K, e O.S. OLESEN, 1973. A polycross pattern formula. Euphytica, Wageningen, 22: 500-502. 
PAULA, J.F. de, 1976. Comportamento de variedades de mandioca (Manihot esculenta Crantz), em Viçosa, Minas Gerais. Viçosa, UFV, 31 p. (Dissertação de Mestrado).

PEREIRA, A.S, e J.O. LORENZI, 1975, Resultados obtidos com a pesquisa de melhoramento e seleção de variedades. In: Inventärio de tecnologia em mandioca. Campinas, $30 \mathrm{p}$.

PEREIRA, A.S., J.O. LORENZI, E.S. NORMANHA e J.R. SILVA, 1978. Fecundação cruzada no cultivar de mandioca Branca de Santa Catarina. Bragantia. Campinas, 37: 45-46.

PINTO, L.R.M., A MIZUBUTI, J.C. SILVA, F.S. GUGLIELMELLI FILHO e R.F. EUCLIDES, 1982. Correlações entre caracteres agronômicos em batatinha (Solanum tuberosum L.). Revista Ceres, Viçosa, 29(163): 284-295.

RAMALHO, M.A.P. e P.A. PEREIRA, 1979. Genética e melhoramento da mandioca. Informe Agropeczario, Belo Horizonte, $\underline{5}$ $(59 / 60): 37-40$.

RIVERO, J.V., 1977. Estudo de algumas características da man dioca (Manihhot esculenta Cranz) em relação a produção inicial de raizes, Lavras, Minas Gerais. ESAL, 56 p. (Dissertação de Mestrado).

ROBINSON, H.F., R:E. COMSTOCK e P.H, HARVEY, 1951. Genotypic correlations in corn and their implication in selection. Agronomy Journal. Madison, 43: 282«287. 
SERA, T., 1980. Estimação dos componentes da variância e dos coeficientes de determinação genotipica da produção de grãos de café (Cobbea arabica L.). Piracicaba, ESALQ/USP, 62 p. (Dissertação de Mestrado).

SILVA, S. de O.C., 1977. Capacidade de produção e caracterís ticas de raizes e ramas de 60 variedades de mandioca. Viçosa, UFV, 47 p. (Dissertação de Mestrado).

SILVA, S, de O. e, W.M.G. FUKUDA, H,W,L, de CARVALHO e R.C. CALDAS, 1983. Estudo do comportamento de cultivares de mandioca no Centro Nacional de Pesquisa de Mandioca e Fruticultura. Revista Brasileira de Mandioca. Cruz das Almas, 2: $9-16$.

STEEL, R.G. e J.H. TORRIE, 1980. Principles and procedures of statistics. 2ạ Ed. Mc Graw-Hill, Book Company Inc. $633 \mathrm{p}$.

TINEO, J.R., 1977. Selección masal de yuca. Revista de la Facultad de Agronomia de la Universidad de Zulia. Maracai bo, $4(1): 23-29$.

TOLEDO, A.P., 1963. Anatomia e desenvolvimento ontogenético da flor de mandioca. Bragantia, Campinas, 22(37): 465-476. . 
TYSDAL, H.M. e B.M. CRANDALL, 1948. The polycross progeny performance as an index of the combining ability of alfafa clones, Journal of the American Society of Agronomy. Madison, 40: $293 \times 306$.

UMANAH, E.E. e R.W. HARTMANN, 1973. Chromosome numbers and karyotypes of some Manihot species. Journal of the American Society for Hortieultural Science. Mount Vernon, 98: 272,274 .

VELLO, N.A., 1977. Seleção dentro de progênies e recombinação por policruzamentos em couve-brócolos ramosa (Brassica oleracea L. var. italica Pleck). Piracicaba, ESALQ/USP. 88 p. (Tese de Doutoramento).

VELLO, N.A. e R. VENCOVSKY, 1974. Variâncias associadas às estimativas de variâncias genëticas e coeficientes de her dabilidade. Relatório Científico do Departamento de Genética, ESALQ/USP, Piracicaba, 8: 238-248.

VELLO, N.A. e R. VENCOVSKY, 1982. Ganho gezëtico esperado com seleção dentro de progênies e recombinação por policrú zamentos. In: Conferência Internacional de Biometria, 10. Guarujāa, 1982, Anais. Brasịia, EMBRAPA, p. 522-534.

VIEGAS, A.P.; 1976. Estudos sobre a mandioca. Campinas, IAC/ BRASCAN/NORDESTE, $214 \mathrm{p}$. 
WELLENSIEK, S.J., 1952. The theoretical basis of the polycross test. Euphytica. Wageninge, 1: 15-19.

WHYTE, R.O., T.R.G. MOIR e J.P. COOPER, 1968. Grasses in Agricutture. Rome, Food and Agriculture Organization of the United Nations. 417 pe (FAO Agricultural Studies, 42) .

WRIGHT, C.E., 1965. Field plants for a systematically designed polycross. Record of Agricultural Research. Belfast, 14: 31.41 .

ZACARIAS, C:A.B., 1977. Estimação de parâmetros genëticos e fenotípicos em clones de cana-desaçúcar (Saccharum ssp.) e suas implicações no melhoramento. Piracicaba, ESALQ/USP, 82 p. (Dissertação de Mestrado). 
.102.

TABELAS

E

APENDICE 


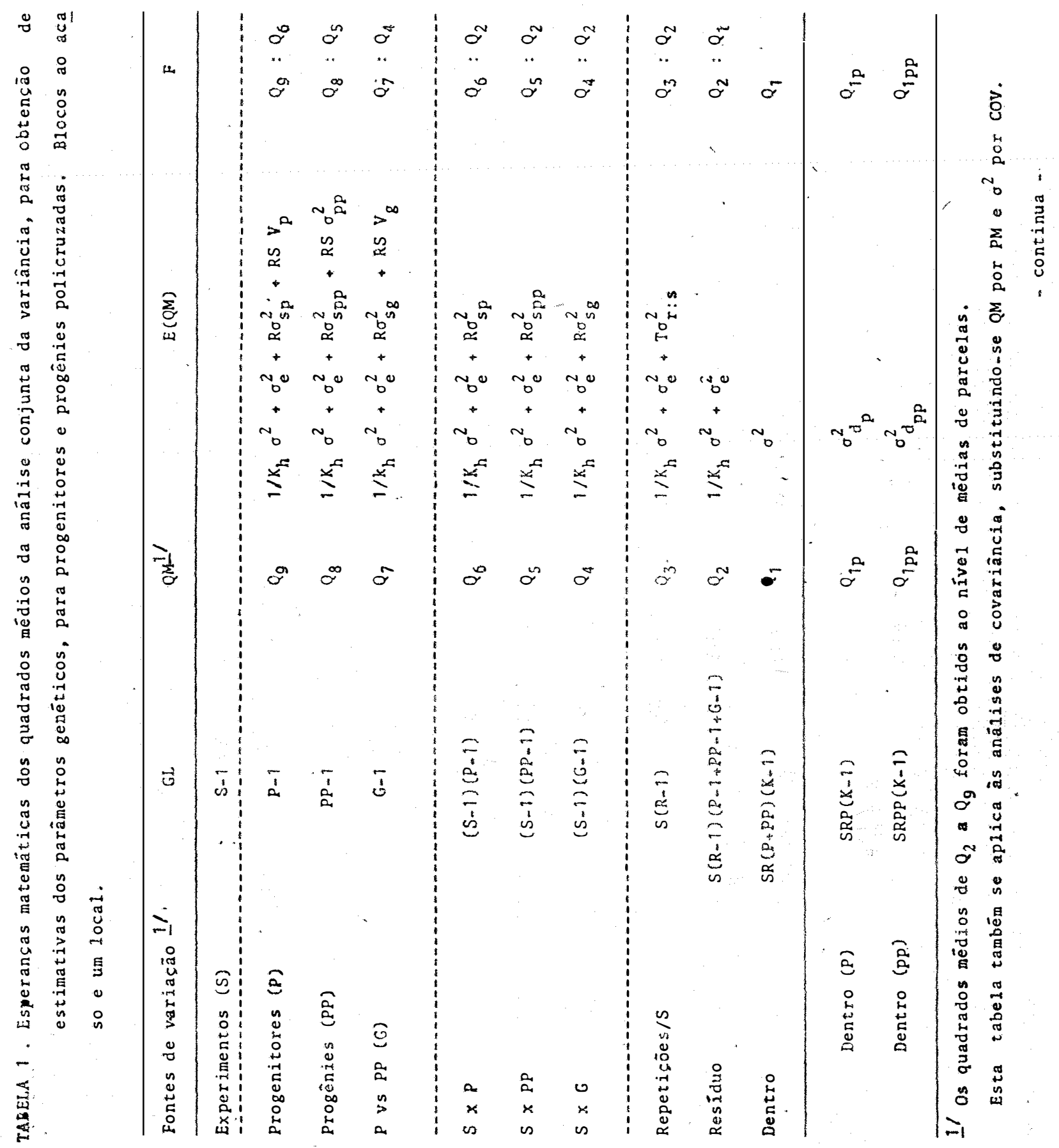




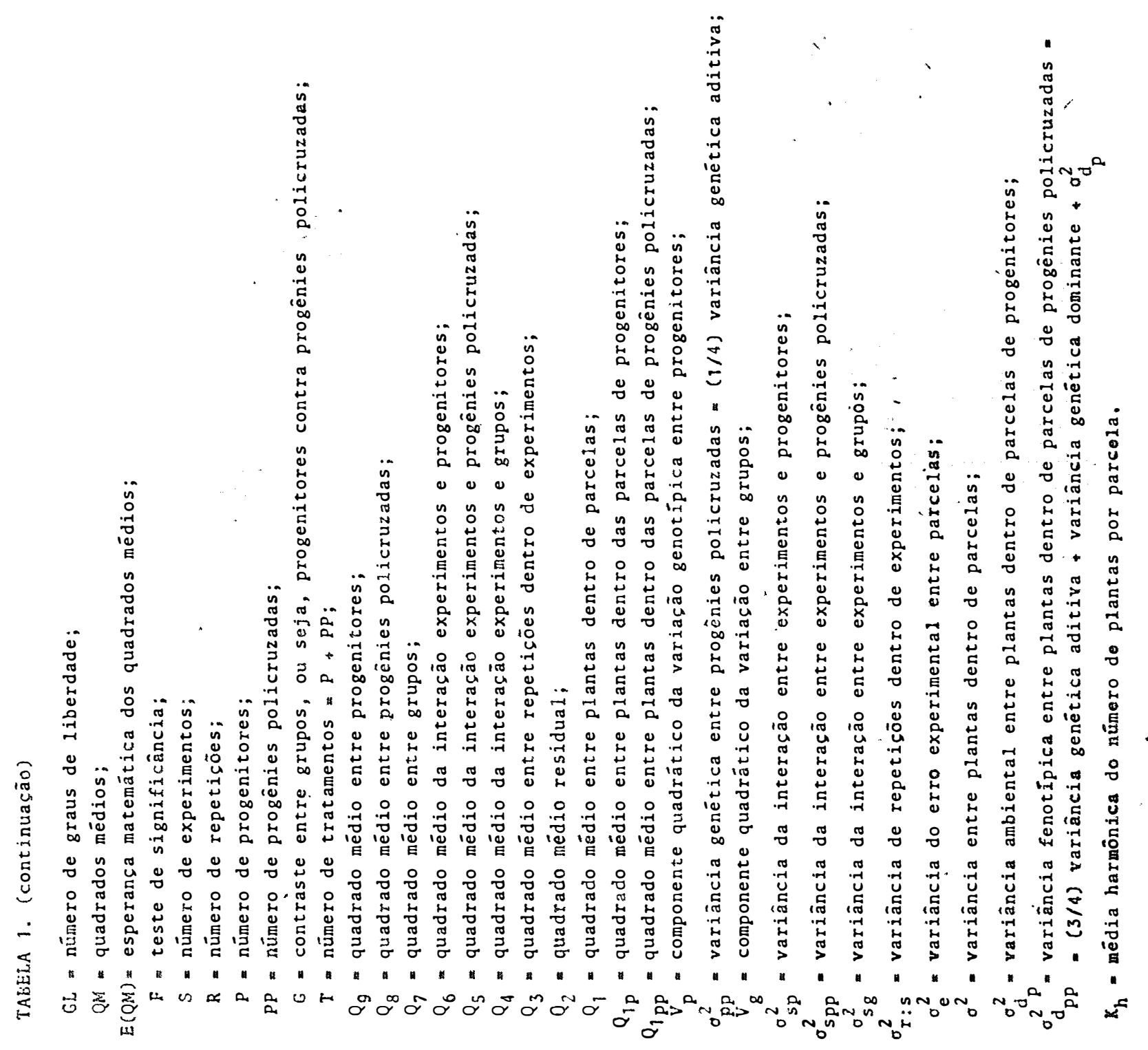


.105.

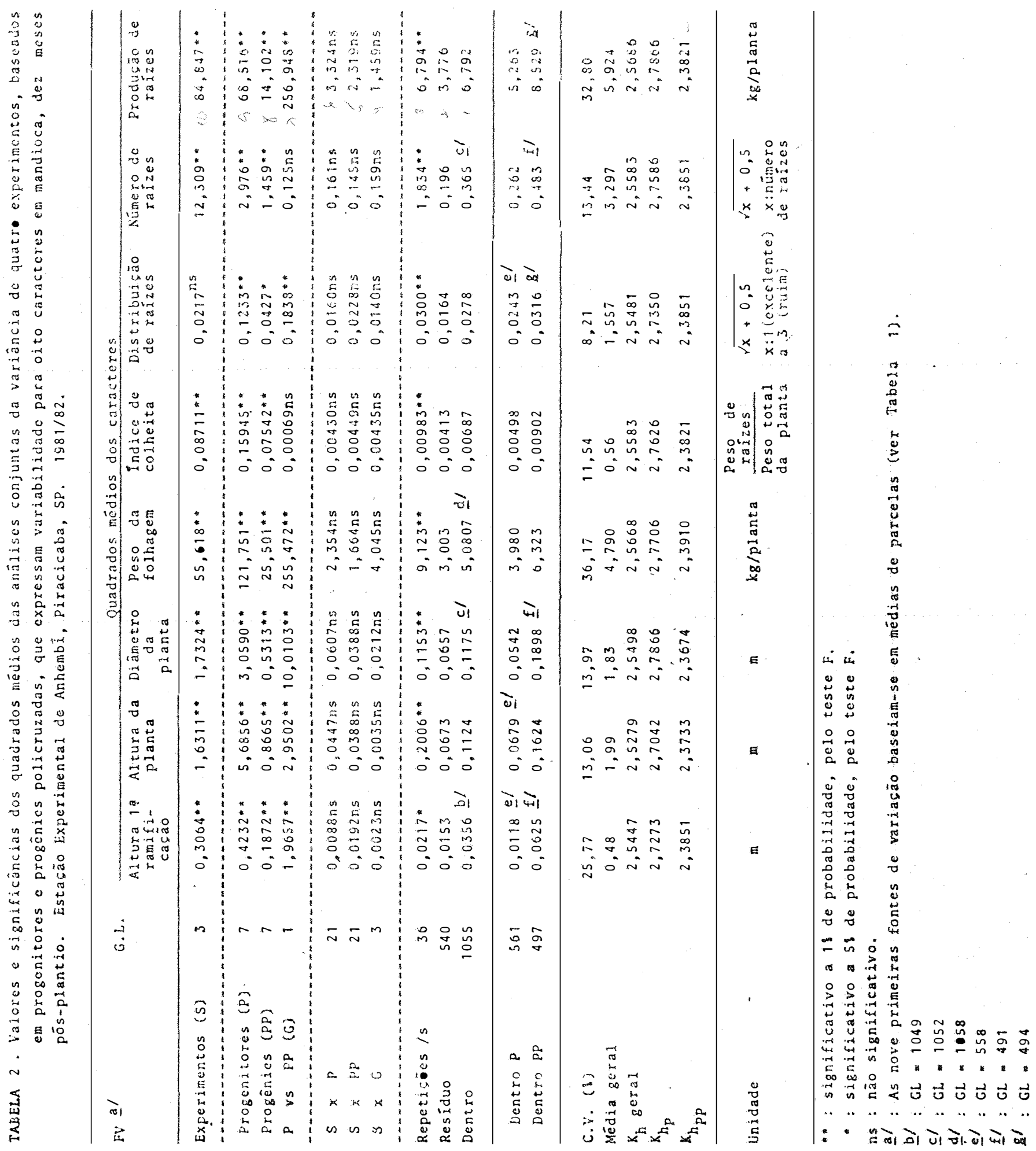




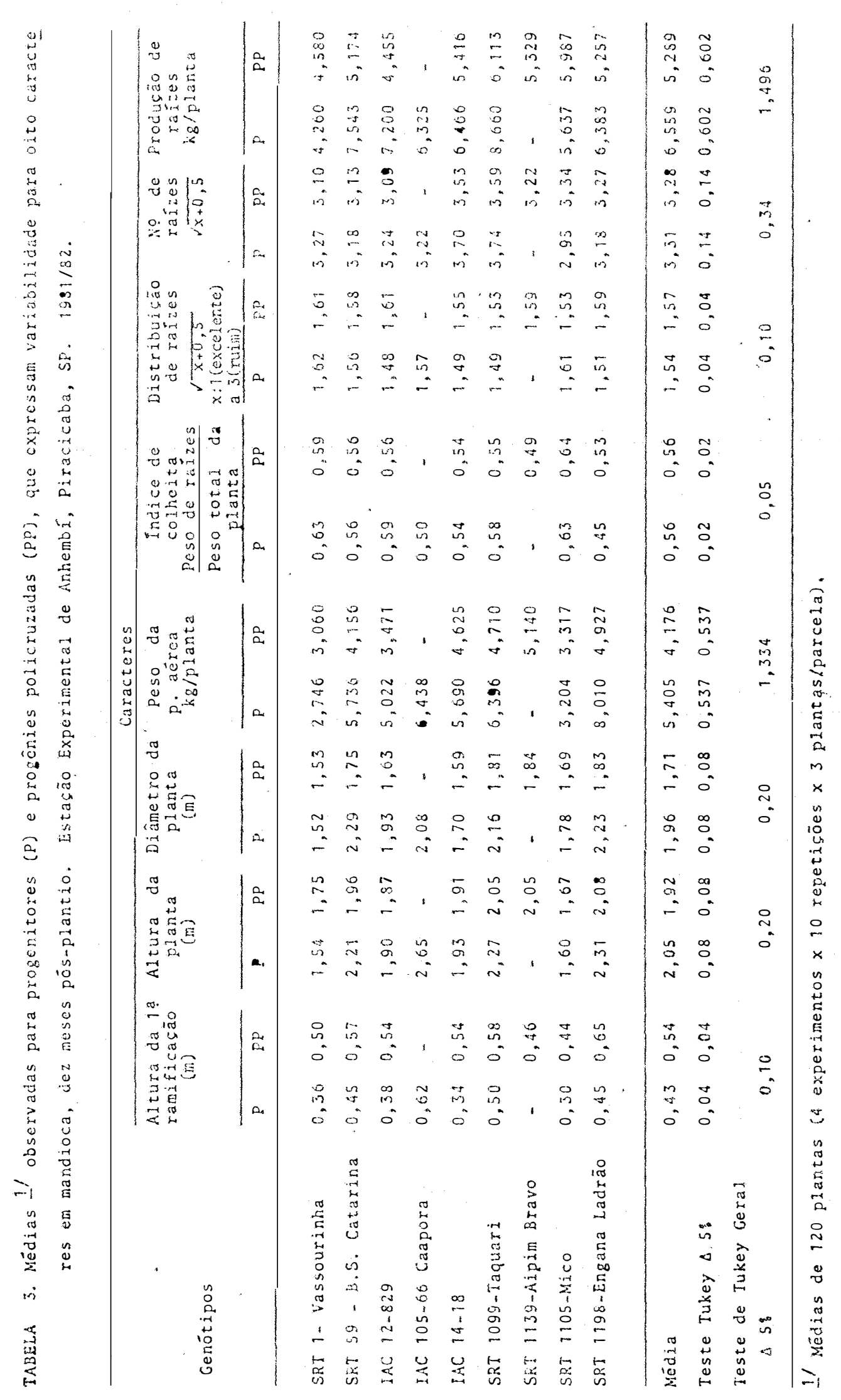




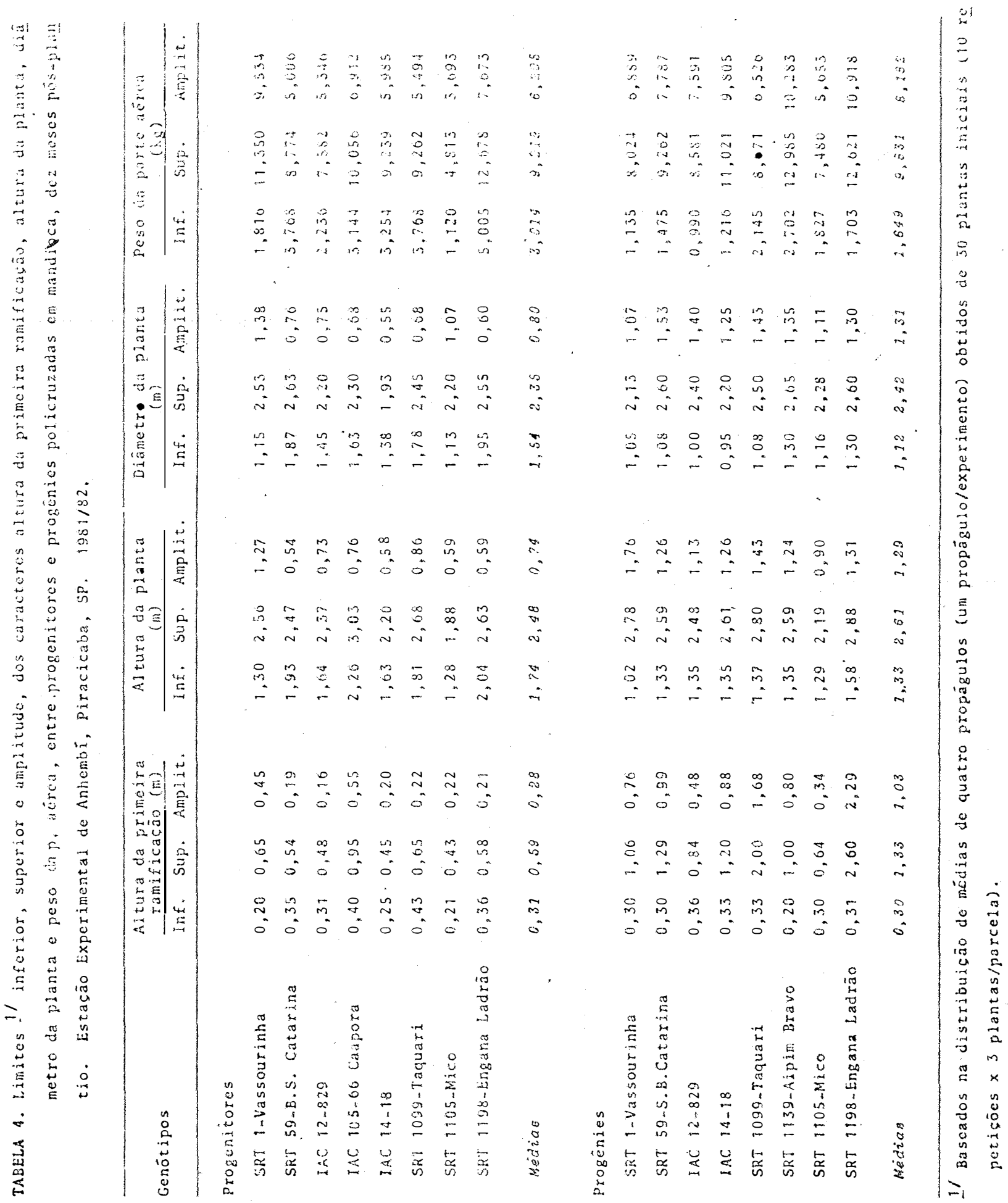




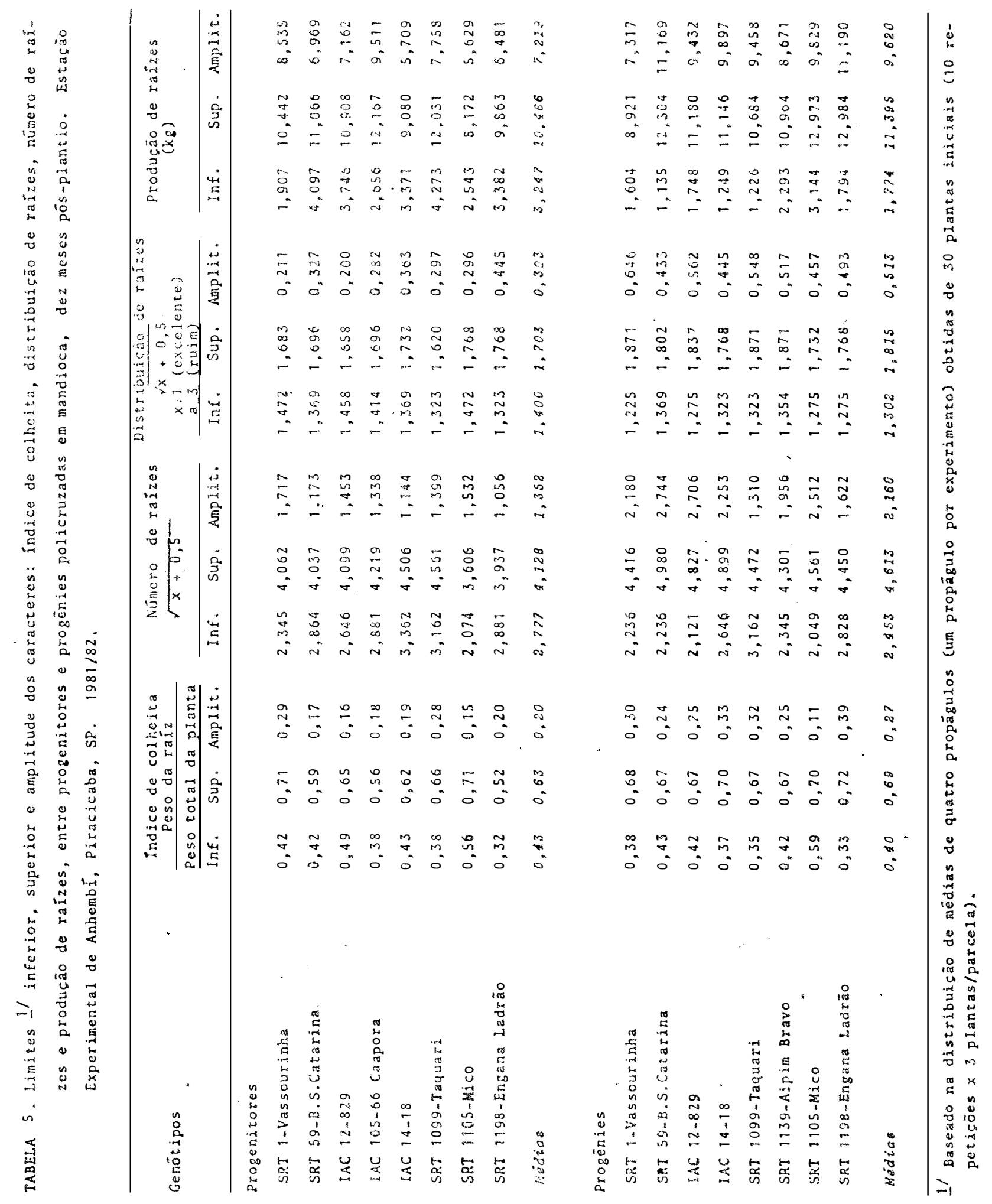


.109.

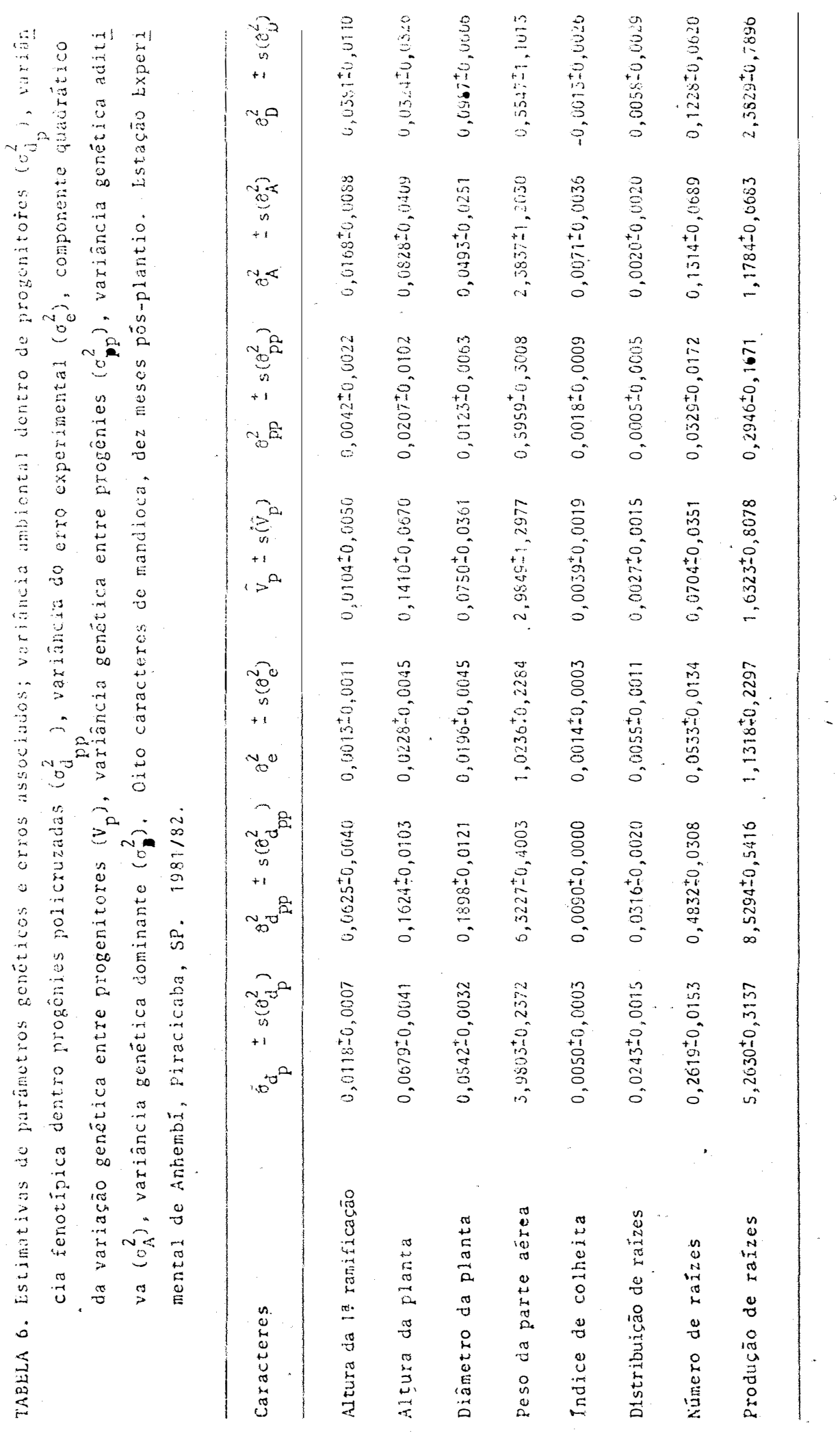


.10.

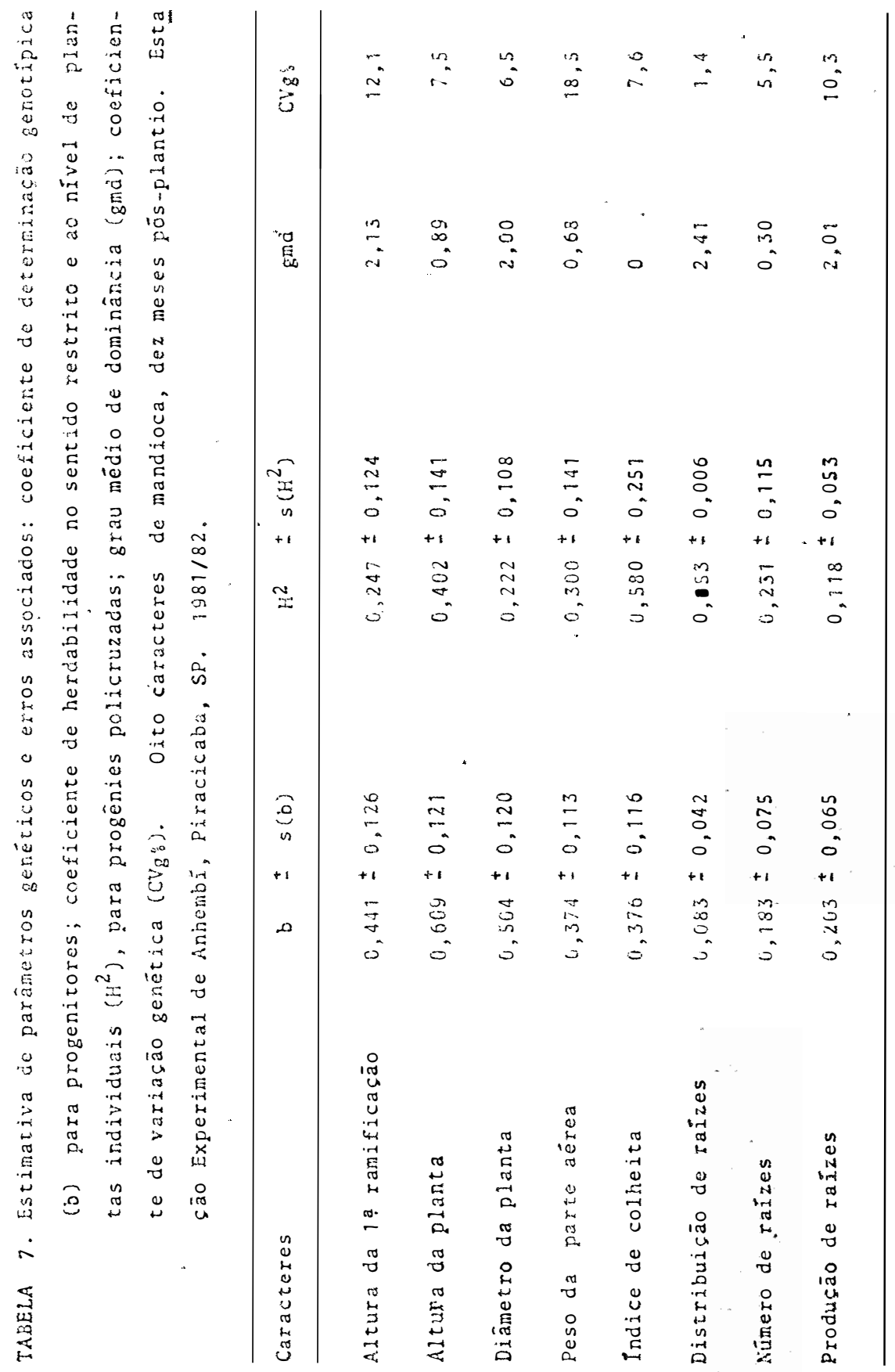




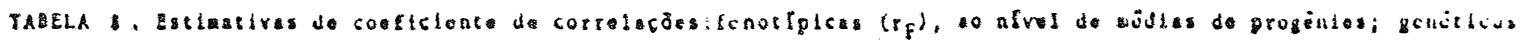

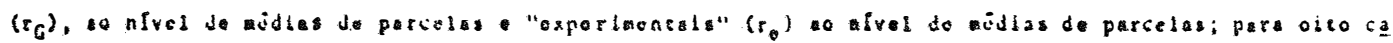

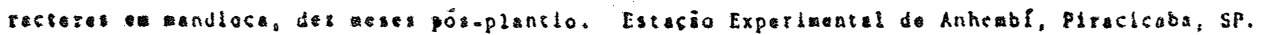

\begin{tabular}{|c|c|c|c|c|c|c|c|c|c|}
\hline Caracteres & Correlacão & $A P$ & $\mathrm{LP}^{\prime}$ & i & ic & $D R i^{\prime}$ & $\lambda \hat{k}$ & & r \\
\hline \multirow[t]{3}{*}{$A R$} & $r_{i}^{r}$ & 0,050 & 0,307 & 0,412 & $-0,401$ & 0,154 & 0,100 & & $-0,05 ?$ \\
\hline & $r_{i}$ & $0.65 i$ & 0.311 & $0,40.3$ & $-0,590$ & $\bullet, 207$ & 0.115 & & $-0,115$ \\
\hline & $x_{e}$ & 0,397 & 0,034 & 0,137 & $-0,231$ & $-0,070$ & 0,051 & . & $-0,007$ \\
\hline \multirow[t]{3}{*}{$A p$} & $x_{F}^{-}$ & & 0.750 & 0,896 & $-0,888$ & 0,074 & 0,234 & & 0,156 \\
\hline & $r_{G}$ & & 0,708 & 0,813 & $-0,930$ & 0.203 & 0,240 & & 0, is? \\
\hline & $\mathrm{r}_{\mathrm{c}}$. & & 0.540 & 0,703 & $-0,304$ & $.0,242$ & 0,241 & ' & 0,408 \\
\hline \multirow[t]{3}{*}{ DP } & $r_{\bar{F}}$ & & & 0,745 & $-0,543$ & $-0,210$ & 0,207 & & 0,508 \\
\hline & ${ }^{r}{ }_{G}$ & . & & 0,765 & $-0,576$ & $-0,2+1$ & 0,225 & & 0,521 \\
\hline & $r_{c}$ & & & 0,647 & $-0,004$ & $-0,265$ & 0,331 & & 0.067 \\
\hline \multirow[t]{3}{*}{$P_{\Lambda}$} & $r_{\bar{F}}$ & . & & & $-0,85 i$ & $-0,1 s 2$ & $0,409^{\circ}$ & & $0,38:$ \\
\hline & ${ }^{x_{G}}$ & & & & $-0,885$ & $-0,208$ & 0,514 & & 0,380 \\
\hline & $r_{\mathrm{c}}$ & & . & & $-0,327$ & $-0,286$ & 0,322 & & 0,702 \\
\hline \multirow[t]{3}{*}{ IC } & $r_{\bar{F}}$ & & & & & $-0,323$ & $-0,0 \$ 7$ & & 0,118 \\
\hline & $r_{c}$ & & & & & $-0,469$ & $-0,028$ & & 0,087 \\
\hline & $c_{c}$ & & & & & $-0,126$ & 0,146 & . & 0,316 \\
\hline \multirow[t]{3}{*}{$\mathrm{DR}=$} & $r \bar{F}$ & & & & & , & $-0,855$ & & $-0,932$ \\
\hline & ${ }^{r_{G}}$ & & & , & & & $-1,202^{-}$ & & $-1,245$ \\
\hline & $r_{e}$ & & ' & . & & & $-0,282$ & & -0.444 \\
\hline \multirow[t]{3}{*}{$N R$} & $r \bar{F}$ & & .. & & . & & & & 0,807 \\
\hline & $r_{C}$ & & & & & & & $\cdot$ & 0,582 \\
\hline & $r_{c}$ & & & & & 冫 & & & 0.457 \\
\hline
\end{tabular}

"AR - slura da pricieira ramificasäo

AP - altura de planta

Dp - diánetro da planca

$p i$ - peso da parte uérea

af

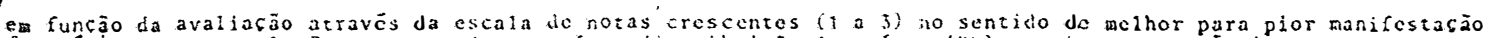

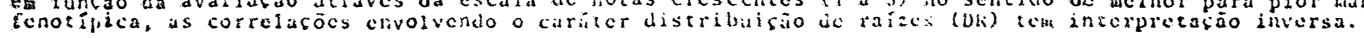

IC. Indice de colheita

DR - Jistribuicão de rázes

$N R$ - riúnero de räzes

$P R$ - producjo de rázos 


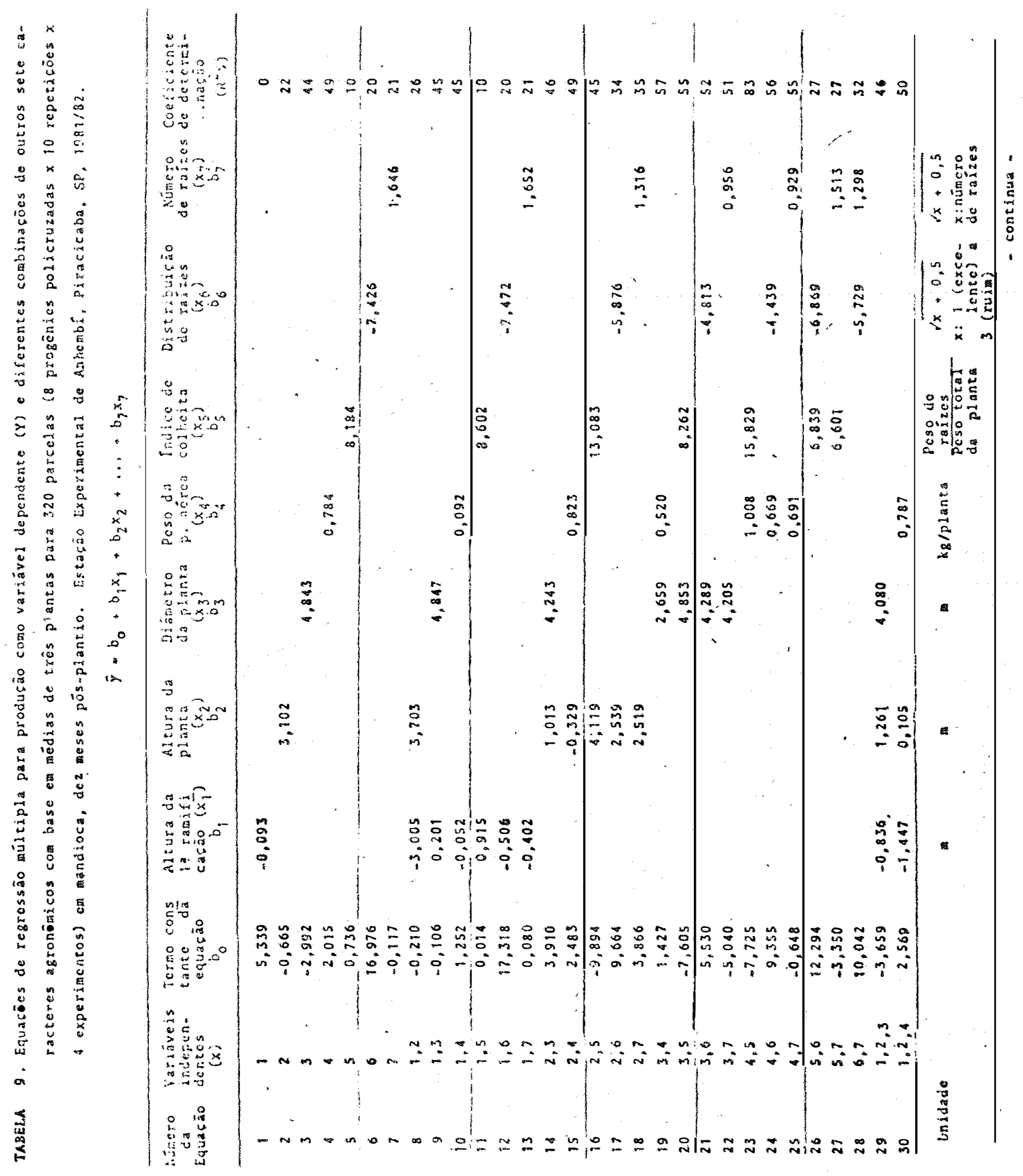




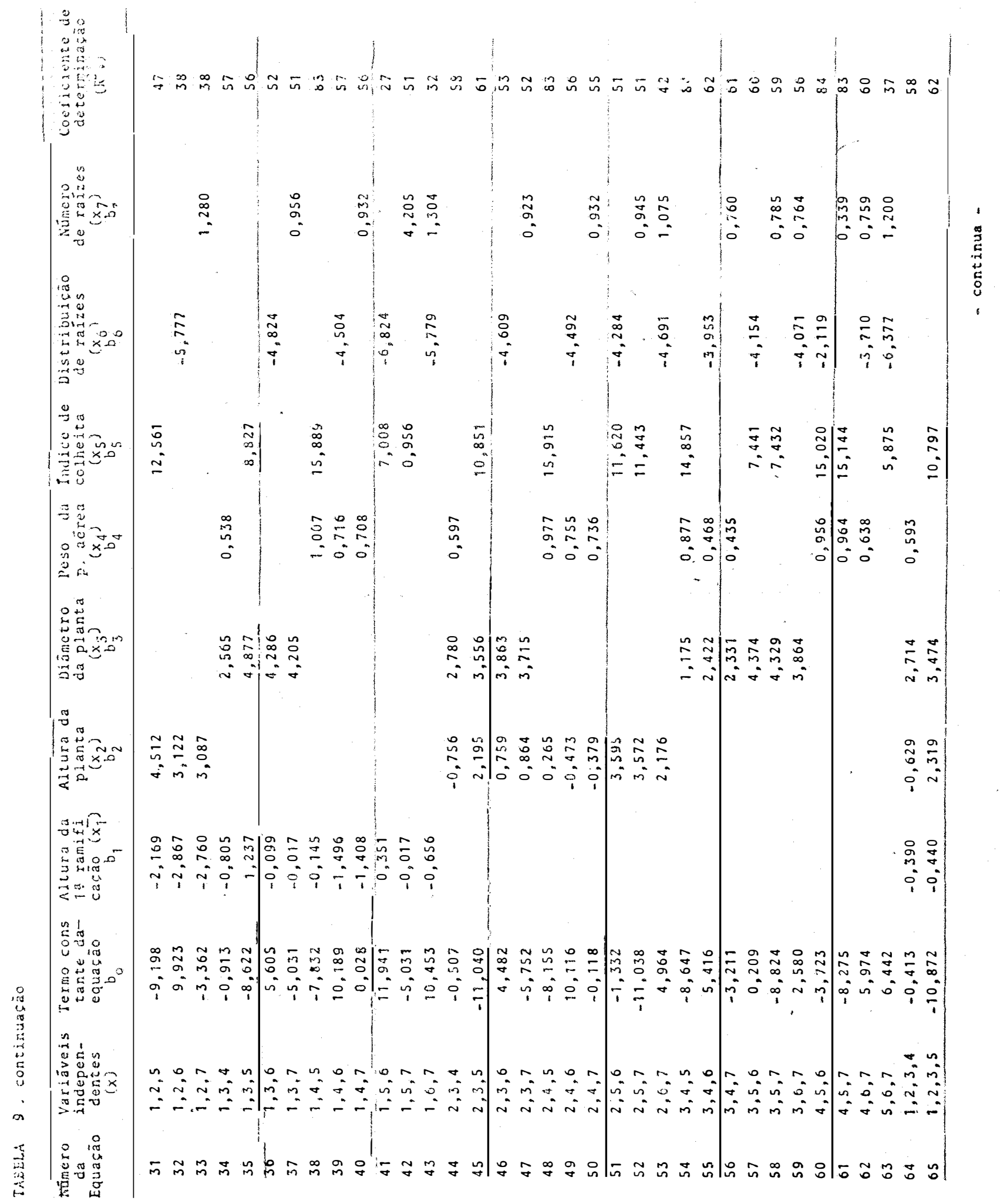




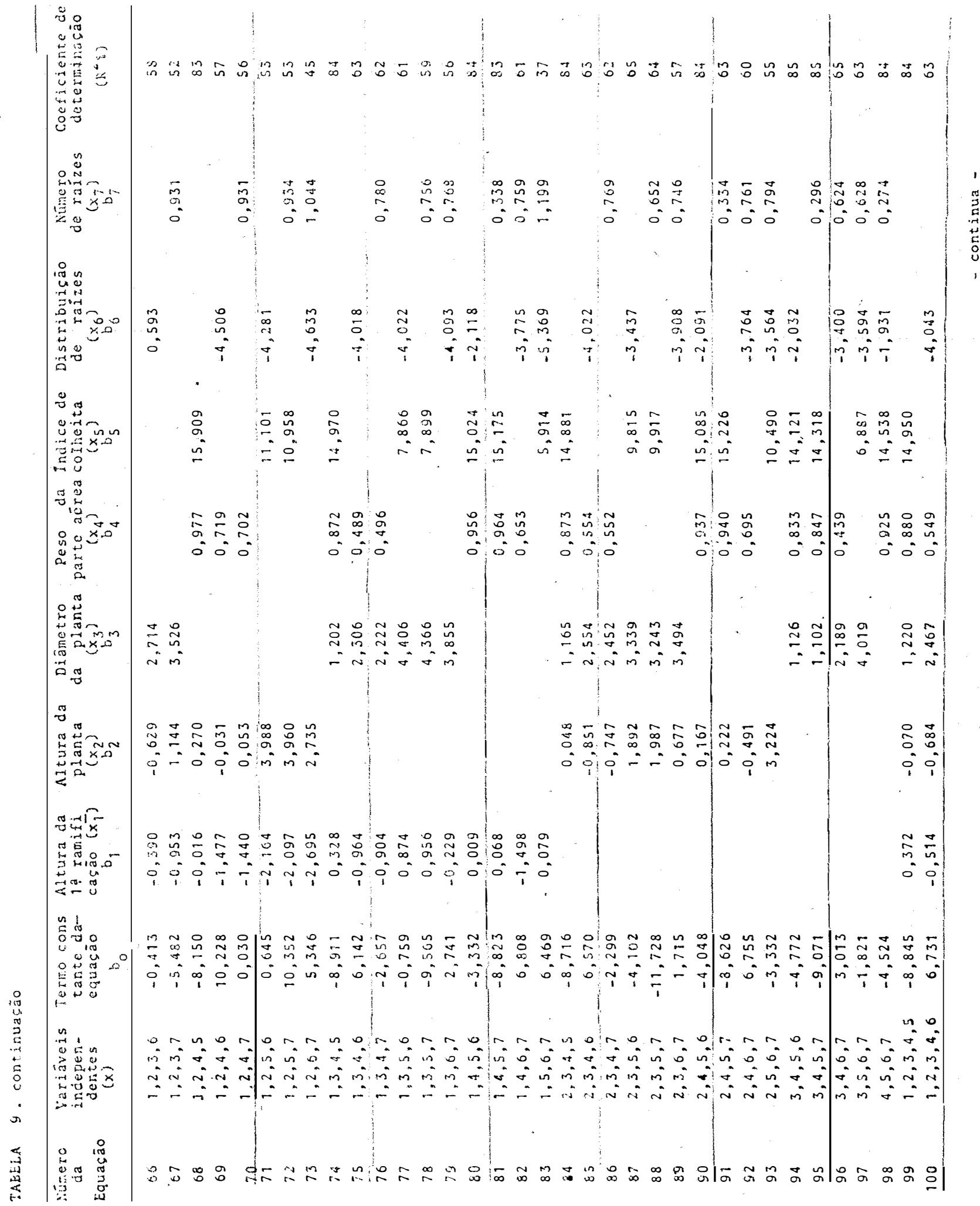


.115.

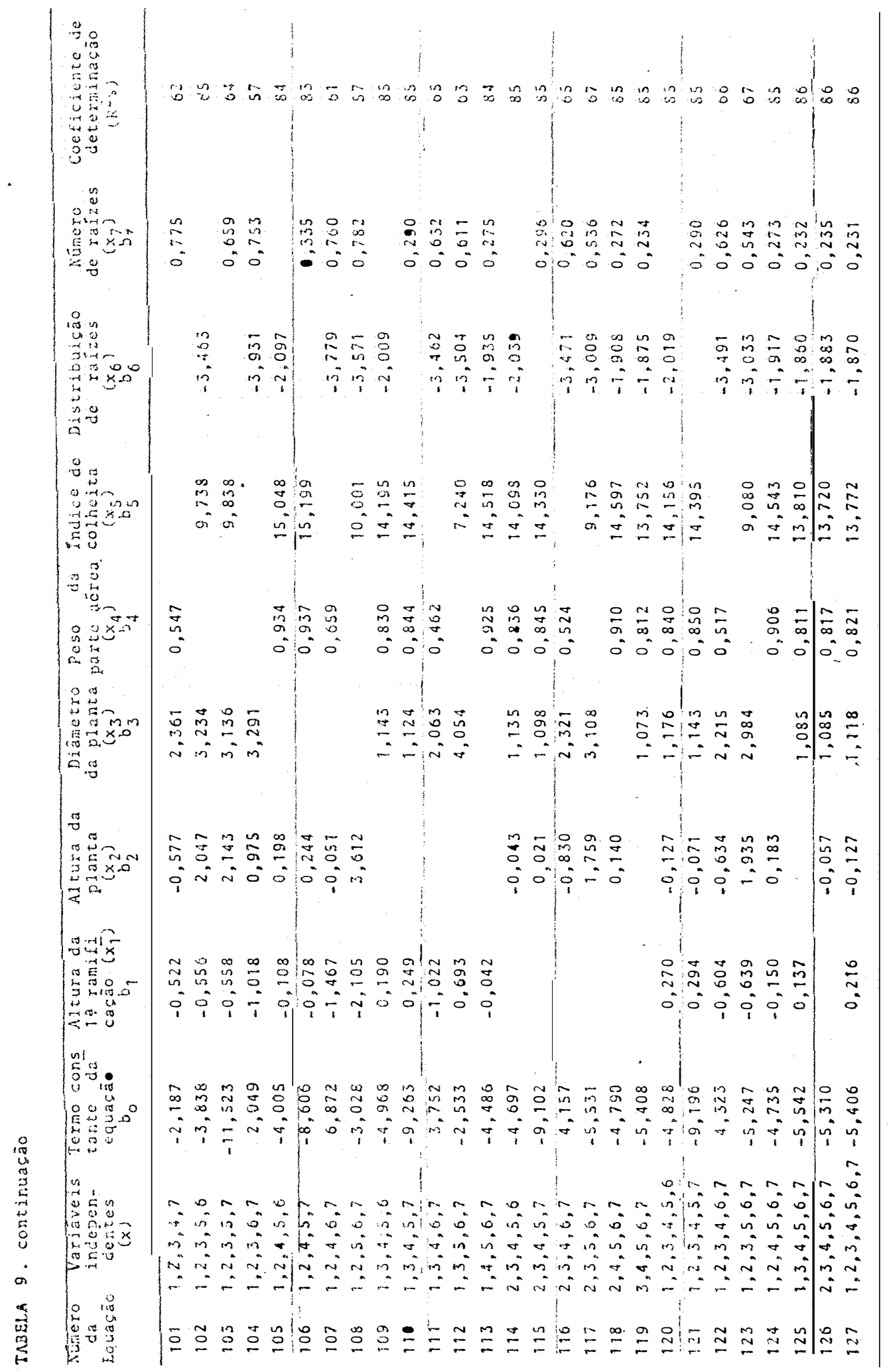




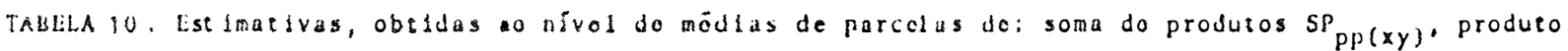

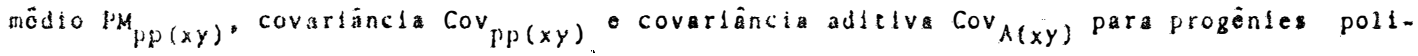

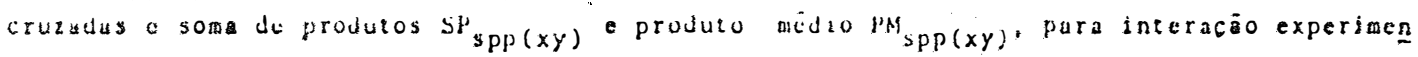
tos $x$ progentes policruzadas. Oito caracteres em mandiocá, dez mescs pos-plantio. EseaGäo lixporiantal de Anteobí, Plraclcaba, SP. $1981 / 82$.

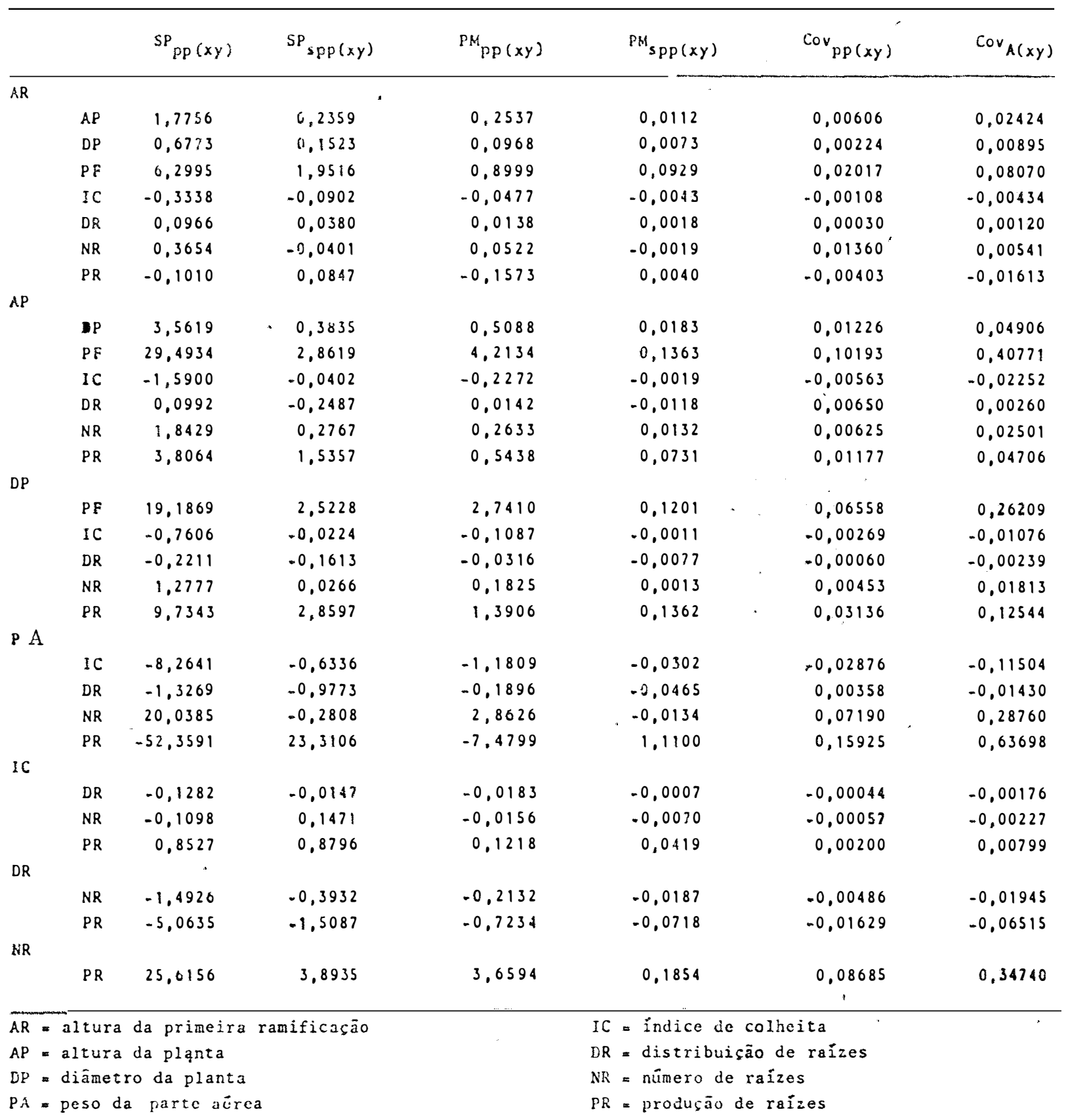




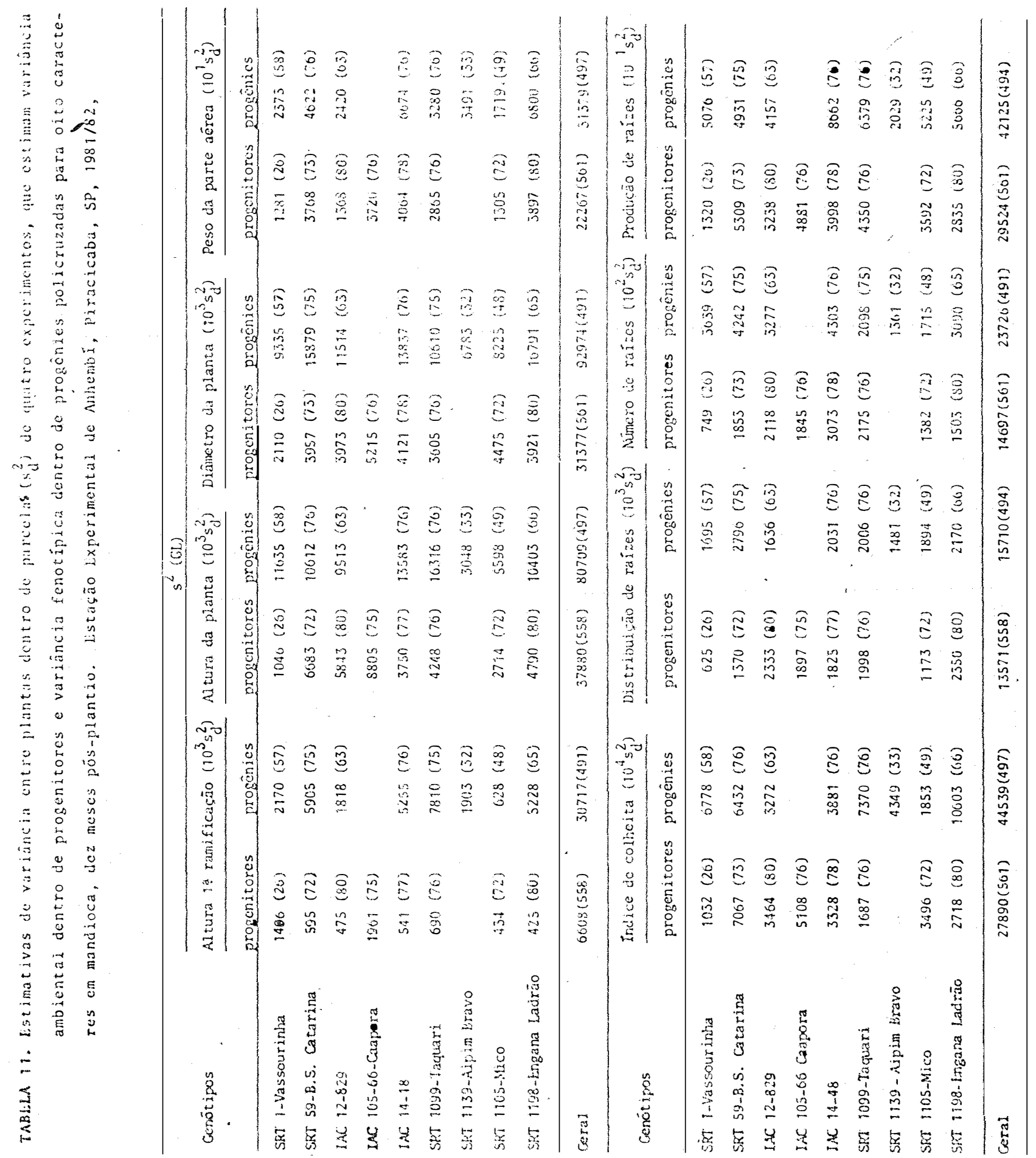


APENDICE 1. Temperaturas máximas, mínimas, médias e precipita ção, durante o período experimental. Estação Experimental de Anhembi 1/, Piracicaba, SP. 1981/ 1982 .

\begin{tabular}{lcccrrr}
\hline Mês & \multicolumn{2}{c}{ temperatura $\left({ }^{\circ} \mathrm{C}\right)$} & & \multicolumn{2}{c}{ precipitação } \\
\cline { 2 - 3 } & mäxima & mínima & média & & mm & dias \\
\hline Setembro/1981 & 31,8 & 19,4 & 25,6 & 15,4 & 2 \\
Outubro & 28,4 & 18,9 & 23,6 & 272,4 & 11 \\
Novembro & 30,7 & 21,2 & 26,0 & 165,2 & 12 \\
Dezembro & 29,5 & 18,7 & 24,1 & 234,2 & 13 \\
Janeiro/1982 & 29,4 & 17,6 & 23,6 & 223,3 & 13 \\
Eevereiro & 32,3 & 19,2 & 25,7 & 308,8 & 13 \\
Março & 29,5 & 18,6 & 24,0 & 114,4 & 9 \\
Abril & 26,9 & 14,0 & 20,5 & 73,2 & 3 \\
Maio & 25,8 & 11,3 & 18,5 & 68,8 & 5 \\
Junho & 25,4 & 13,6 & 19,5 & 164,2 & 9 \\
Julho & 25,1 & 11,7 & 19,0 & 35,4 & 5 \\
& & & & & \\
\hline Média geral & 28,6 & 16,7 & 22,7 & & \\
Total & & & & $1.675,3$ & 95 \\
\hline
\end{tabular}

$1 /$ Dados fornecidos pela Seção de Agroclimatologia do Programa-Nacional de Melhoramento da Cana-de-Açücar, IAA, Planal sucar. Anhembí, São Paulo.

APENDICE 2. Análise quîmica do solo da Estação Experimental de Anhembi 1/, Piracicaba, SP.

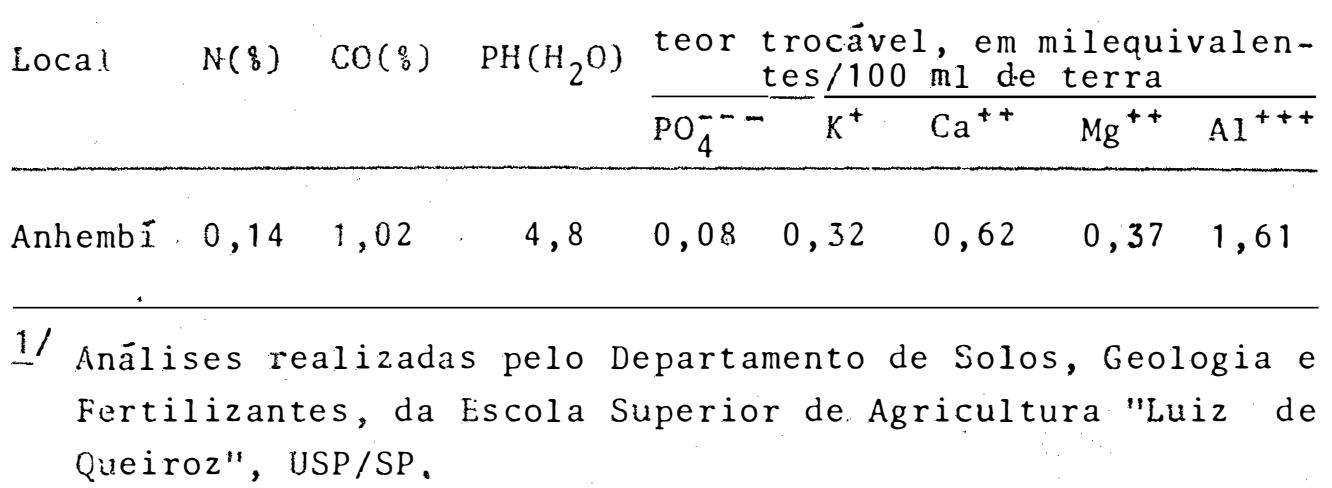

